\title{
THE HERITABILITY OF MILK YIELD \\ AND FAT PERCENTAGE IN THE FRIESIAN CATTLE IN THE PROVINCE OF FRIESLAND
}




\section{THEOREMS *)}

1. Measuring the intensity of inbreeding practiced in the Friesian Herdbook cattle, can help in getting an idea in how far the genotype, according to the milk yield, has changed in the last half century.

2. If it is at all possible, it is advisable to avoid the use of correction factors for non-genetic influences in daughter-dam comparisons.

3. It is not right to speak about breed differences in heritability.

4. The comparisons of relatives are expected to give more accurate estimates of heritability of a quantitative character, if the population under study is reared under such conditions that are on the average optimal for phenotypic expression.

5. Using daughter-dam comparisons to estimate the heritability of production in cattle, regression is prefered to correlation.

6. In estimating the breeding value of a sire, too much value is often set on the uniformity of his progeny.

7. Blindness in new born lambs, proved to be a recessive.semilethal character which appears by intensive inbreeding.

8. The experiences with the West Europian breeds of sheep make it very doubtful whether these breeds have an economical value for Egypt.

9. The Egyptian law of agrarian reform promulgated on Sept., 9th 1952, took decisive measures to protect the country against the evils of feudalism which had badly injured its social and economical life.

10. In planting cotton in clay soil in Egypt, it is preferable to cover the seeds with a mixture of $1: 3$, in order to get earlier plants with higher yield.

*) A.S. Hornby, E.V. Gatenby and H.Wakefield, 1953, The advanced learner's dictionary of current English; 4th impression, page 1333. 
THE HERITABILITY OF MILK YIELI) AND FAT PERCENTAGE IN THIE FRIESIAN CATTLE IN THE PROVINCE' OF FRIESLANI) 
Dit proefschrift met stellingen van SHIMY ABDEL FATTAH EL-ShIMY landbouwkundig ingenieur. geboren te CAITRO,

2 juli 1923. is goedgekeurd door de promotor Ir. W. DE JONG hoogleraar in de veeteeltwetenschap.

De Reclor Magnificus der Landbouwhogeschool. J. H. BECKING

Wageningen. 19 januari 1956 


\title{
THE HERITABILITY OF MILK YIELD AND FAT PERCENTAGE IN THE FRIESIAN CATTLE IN THE PROVINCE OF FRIESLAND
}

\author{
PROEFSCHRIFT \\ TER VERKRIJGING VAN DE GRAAD \\ VAN DOCTOR IN DE LANDBOUWKUNDE \\ OP GEZAG VAN DE RECTOR MAGNIFICUS DR J. H. BECKING \\ HOOGLERAAR IN DE HOUTMEETKUNDE, \\ DE BOSBEDRIJFSECONOMIE. DE BOSBEDRIJFSREGELING \\ EN DE HOUTTEELT EN BOSBESCHERMING IN DE TROPEN. \\ TE VERDEDIGEN TEGEN DE BEDENKINGEN \\ VAN EEN COMMISSIE UIT DE SENAAT DER \\ LANDBOUWHOGESCHOOL TE WAGENINGEN OP \\ VRIJDAG 23 MAART 1956 TE 16 UUR
} DOOR SHIMY ABDEL FATTAH EL.SHIMY 


\section{THE HERITABILITY OF MILK YIELD AND FAT PERCENTAGE IN THE FRIESIAN CATTLE IN THE PROVINCE OF FRIESLAND}

\section{THIESIS}

IN PARTIAL FULFILMENT OF THE REQUIREMENTS

$$
\text { . . FOR }
$$

THE DEGREE OF DOCTOR OF AGRARIAN SCIENCES

AT THE

AGRICULTURAL UNIVERSITY OF WAGENINGEN

ON

FRIDAY 23 MARCH 1956 AT 16 O'CLOCK

BY

SHIMY ABDEL FATTAH EL-SHIMY

BORN IN CAIRO ON 2nd JULY 1923

WAGENINGEN

THE NETHERLANDS

1956 
To those I met in life, whether they remained loyal or disloyal. 


\section{A CKNOWLE. DGMENTS}

The writer wishes to express his thanks to all the people of the "Friesch Rundvee Stamboek", for providing facilities for this research. The encouragements of Dr. E.T. Roelofs and Ir. A.H. Nubé are not neglectable.

The efforts of Prof. Ir. W. de Jong, are greatly appreciated for his supervision and help during the course of this investigation. The writer is also greatly indebted to $\mathrm{Dr}$. Th. de Groot, and Ir. $\mathrm{K}$. Bosma, for their excellent guidance and criticism.

Cordial thanks to every body else who has contributed in any way to this research work. 


\section{CONTENTS}

CHAPTER I

page

Introduction

CHAPTER II

Review of literature $\quad 14$

A. Milk yield 14

B. Fat percentage $\quad 18$

C. Fat yield 20

D. Other characters concerning milking abilities 22

CHAPTER III

Material

Soil and feeding

26

$\begin{array}{ll}\text { Conditions of research } & 28\end{array}$

CHAPTER IV

Methods used $\quad 33$

CHAPTER V

Results

A. Milk yield $\quad 35$

B. Fat percentage 41

CHAPTER VI

$\begin{array}{ll}\text { General discussion } & 47\end{array}$

1. Age of cow at calving 47

2. Length of lactation period 49

3. Month of calving 53

4. Effect of feeding conditions 54

5. Effect of temperature 56

6. Number of records needed $\quad 57$

$\begin{array}{ll}\text { Heritability estimates } & 64\end{array}$

CHAPTER VII

Conclusion $\quad 66$

CHAPTER VIII

Summary:

In English $\quad 67$

In Dutch $\quad 69$

BIBLIOGRAPHY 


\section{Chapter I}

\section{INTRODUCTION}

The series of problems set for the dairy breeder resolve themselves into how he is to proceed in breeding superior producing animals. In the past, most attention in improving dairy cattle has been paid to form and type. The attention after that was paid to the production of milk, and the milk control systems were founded. A further step, was to understand the fundamental basis of genetics and their application to dairy breeding. It is natural enough that the current state of understanding of this point, and that the progress in such understanding, has not always been easy, and that workers with different preconceptions have not always given equal weight to the same circumstances.

The widest developed method in the field of population genetics that!lights. the way in the trial to find out the genetical back ground of the animal, is estimating the heritabilities of the characteristics under study.

The causes of observed variation between related individuals, are not all attributed to their genotypes. The phenotype of an individual is the net gain of both environment and heredity.

Characters are different from each other in their response to environmental changes. The more stable the character is when conditions of environment are changed, the more its expression is controlled by heredity. Winters (1950) illustrated the heredity of a character as a dot in the middle of a circle which represents the individual's hereditary possibilities and limitation at the time of fertilization. A satisfactory environment is necessary for the individual to fill the circle; but inspite of its environment, it cannot go beyond the bounds of its heredity. This means that the phenotype of the individual is determined both by heredity and environment, and a deficiency in either will interfere with maximum expression of the character.

Environmental factors, especially nutrition, determine whether the maximum production will be reached, and an optimum nutritional regime is one which enables the individual to take full advantage of its heredity. In accord to the basic concept, however, the maximum production fixed by heredity; cannot be exceeded by nutrition or by any other means, in the normal individual.

The components of the observed variances, or the phenotypic expression of the individual, can simply be shown by figure No 1 , where:.$\sigma G^{2}=$ Genes act in an additive way.

$\sigma I^{2}=$ Epistasis or non-additive interaction of genes.

$\sigma D^{2}=$ Dominance effect. 
$\sigma(\text { P.E.E. })^{2}=$ Permanent environmental factors.

$\sigma \mathrm{E}^{2} \quad$ Environmental factors.

$\sigma$ (Int.E.H. $)^{2}=$ The interrelation between environment and heredity.

$\sigma \mathrm{H}^{2} \quad=$ Heredity factors.

$\sigma \mathrm{P}^{2}=$ The phenotype of the individual.

\begin{tabular}{|c|c|c|c|c|c|}
\hline$\sigma G^{2}$ & $\mathrm{fl}^{2}$ & $\sigma D^{2}$ & $\sigma(P . E . E .)^{2}$ & $\sigma E^{2}$ & $\sigma(\operatorname{Int} . E \cdot H \cdot)^{2}$ \\
\hline & $\mathrm{H}^{2}$ & & & & \\
\hline
\end{tabular}

Fig. 1. The partitioning of the observed variance to its causes.

Lush (1940) defined the degree of heritability of a character $\left(h^{2}\right)$, as the fraction of the observed variance which was caused by differences in heredity.

As far as the animal is concerned, its genotype functions as a unit. This actual functioning of the genotype as a whole, is what Lush meant by the broad definition of $h^{2}$. From figure 1 , this means that $\mathrm{h} 2$ in its broad sense $=$

$$
\frac{\left.\sigma \mathrm{G}^{2}+\sigma \mathrm{D}^{2}+\sigma \mathrm{I}^{2}+\sigma(\text { Int. E. H. })^{2}+\text { small part of } \sigma(\mathrm{E})\right)^{2}}{\sigma \mathrm{P}^{2}}
$$

As the gene, and not the whole genotype, is the unit in transmission from parents to offspring, and assuming that each gene substitution has in every genotype exactly the same effect as the average effect which it actually does have, then by adding all these average effects of the constituent genes, we can get an "expected" value for each genotype. This value is what Lush called the heritability in the narrow sense; and it equals $=\frac{\mathrm{G}^{2}}{\mathrm{P}^{2}}$

Without modern statistical analysis, the early studies demonstrated that milk production, fat production, and fat $\%$, are influenced by heredity. Rietz (1909) gave evidence that fat yield is inherited to an extent that allows some prediction of an individual cow's record from those of its ancestors. Other former investigators, like Hansen (1917), Gowen (1920), Turner (1927), and Yapp (1928-29), concluded that milk and fat yields are influenced by many genes, and that the genes for high production tend to be dominant, and that not all genes have the same effect. The crossbreds generally resembled the high parent more closely than the low parent; i.e. there is partial dominance of factors for high production.

Madsen (1932) concluded that there was no correlation between the milking capacity index of a bull and the capacity of his paternal granddam, while the correlation between bull's milking capacity index and the production of his maternal granddam was significant. While this investigator concluded a sex-linkage as playing a rôle in milk production, Smith and Robison (1933) concluded that sex-linkage does not play a large part in inheritance of milk yield.

Up till now, no major genes for milk production, nor for fat, have yet been identified separately. Many of the early attemps 
tried to explain differences in production on the basis of a limited number of genes, theoried by simple Mendelian hypothesis. The method of Von Patow (1925-30) that was modified and induced in practice by Groeneveld in the Friesian cattle Herdbook in Fries land, till before the last world war, gives an excellent example for such attempts.

The method is based upon the assumption that the milk yield inheritance is dependent upon four pairs of factors, while the fat percentage inheritance depends upon five pairs; each factor has the same value, and the influence of the homozygote is double that of the heterozygote.

The recent studies indicated dominance and epistatic effects to play a part in heredity of production of milk and fat. The rate of improvement in such characters depends on their hereditary values. The following part (Lush 1949) expresses simple ideas on this last point:

1. If $h^{2}$ is high, we use mass selection, because we are sure that the character will be translocated to the offspring.

2. If most of the variation is due to environmental factors, we use progeny testing and pedigree selection as a criterion to improve the character.

3 . If the interactions of genes play a great part in the variation, we better get cross lines between inbred animals to obtain the desirable combination of genes necessary for the maximum yield of the trait in question.

The way of estimating a sire's breeding value from the phenotype of his progeny, is carried out by the breeding association "Friesch Rundvee Stamboek", in Friesland, using a graphic daughter-dam comparison of milk yield and fat percentage records. Using this method or any other to examine the sire index, the genotypes of the offspring and their dams under comparison, are unknown, and the bull's index is only estimated from their phenotypes.

As far as the pairs of dam-daughter comparisons are a random sample, errors from different genotypes can be made zero, or insignificantly small, by increasing the number of comparisons, so that the plus values and the minus values will be about equal. In practice, usually the daughters and mates of one bull, are kept under different environmental conditions as the daughters and mates of another bull. To compare the indexes of different bulls, such method is not a good measure of the superior transmitting ability of a bull, especially with characters like milk yield. where most of the variance is due to environment.

Using the heritability estimates, lights the way to show us to how great an extent we can depend on the phenotype as an expression of the genotype.

Since the components of comparisons within each sire indicate deviations from averages, Lush and McGilliard (1955) said that each of these variables will sum to zero, when as is the case of the present study, several sires, each with many daughters are considered, and the plus values and minus values will be about equally frequent.

The methods which are used in estimating the heritability are: 
1. More reliable results are expected from experiments involving , the exposure of monozygous twins to different environments. Differences which result between such twins are utterly environmental, since members of such pair of twins are genetically the same..Lush:(1939) stated that the ideal method of estimating the degree of heritability of characteristic, is to compare the variance of that characteristic in the: original population, with the average variance within isogenic lines derived from that population. In:populations of farm animals, the only isogenic lines available are; monozygous twins.

There are two main difficulties to get identical twins in cattle breeding: A . to produce twins. B. having produced them, to identify them as monozygotic.

2 - The : second method to estimate the heritability is that; if we devide the selection differential (the degree by which those selected to be parents excel the average of their generation population), by the amount their offspring exceed the average of the parents $^{\prime}$ generation population, we can measure the heqritable portion of: variance of the character. Lush (1949) said that "in order.not to be: misled by unnoticed environmental changes, it is usually necessary that the selection be practiced in opposite directions at the same time; iso that the interpretation will be based on differences between the high and the low lines". Such method is available in plant, ibreeding, but in animal field, no breeder, nor experimental station, would agree to select in the undesired direction, for the purpose of estimating the heritability of the character. 3.: The : most applied method in estimating the heritability in anii:mal breeding is the comparison of the amount of resemblance or differences found between related animals. As stated by Lush (1949): the general fact that an animal gets half of its inheritance from each parent, would naturally lead to one form of what is generally: called "'Galton's law"' (1815).

Based on this law of inheritance, it was possible by the application of Wright's formula $(1920-21)$ for the parent-offspring correlation, to estimate the proportion of the variance within each group, which is due to heredity, assuming that there is no dominance or interaction (nicking), and that mating is at random within groups.

Lush (1939) mentioned that "such estimates include the additively genetic portion of the variance, plus part of the epistatic variance, and in some relationships, part of the variance caused by: dominance deviations from the additive scheme".

The most dependable estimates are based upon the closest relationships (parents/offspring or full sibs), because the sampling errors are thereby kept relatively small compared to that which is being estimated. Relatives more remote than half-sibs, are rarely of much use for estimating heritabilities, since the genetic correlations expected are relatively small compared to their sampling errors.

The correlation between dam daughter is: $r_{p o}=\frac{1}{2} h^{2} ;$ where $h^{2}$ is the heritability of the character.

Lush and Strauss (1942) preferred doubling the intra-sire regression of daughter's records on dam's records, as the mọst 
dependable method to estimate " $\mathrm{h} 2$ " of the characters, where the sire cannot express the characteristic himself, and where the dams are likely to have been a bit more highly selected than the daughters, and especially because feeding and other managements practiced are almost certain to have differed considerably from herd to herd.

About all the investigations done in this field we re carried out with the aid of using correction factors for different environmental conditions. As such correction factors are obtained through averages, no thorough information is known about the efficiency of applying them to individual animals' productions. They may be deceiving more than correcting. This evoked the idea to study the heritability of milk yield and fat percentage, without using these correction factors. The practical difficulty was how to find sufficient numbers of dam-daughter pairs of animals that were reared under nearly similar conditions, and at the same moment had yielded normally within approximately similar normal lactation periods.

The data found in the province of Friesland on the registered cattle were excellent to serve such investigation. The isolated position of this province, and the fact that all the sires used mostly descended from one line of blood, may account for the homozygosity of a number of genes involved in establishing the typical and desired qualitative performance of milk and fat production in this breed.

The question we wished to answer in this study was: To what extent does heredity play a part in directing the improvement of milk and fat production in the Friesian breed? 
In planning genetic improvement, it is essential to know the heritability of the traits concerned. In animal breeding, this has been greatly simplified in the approach usually associated with the names of R.A. Fisher, Sewall Wright, and Jay Lush. It is now often possible in a given material to compute the proportion of the total variation resulting from hereditary causes. Such investigations have recently been done in the field of dairy breeding in different parts of the world.

\section{A. Milk yield:}

Axelsson (1933) from correlations between dams and daughters in the Lowland cattle at Malmöhus Län concluded that the average heritability value of milk yield was 0.422 . This estimate came from doubling the average correlation $0.211 \pm 0.0794$.

The same investigator (1934) correlated the production records of the daughters of twelve sires of the Swedish Friesian breed, with the records of their dams. The average correlation for milk yield was $0.16 \pm 0.0701$. For all the pairs of daughters and dams investigated together (not individually for the sires), the correlation coefficient was $0.201 \pm 0.0524$. Such a high correlation would be of a great practical importance for selection in breeding for milk yield. In the last part of his research, the investigator changed the method, to obtain more reliable results. All the normal yearly records for each cow, were corrected, and the average yield was correlated between dams and daughters. The result was $0.211 \pm 0.0794$. This was the same result obtained by the same investigator in his first study mentioned above. He concluded that the latter method is of greater value than the one used in the first part of his investigation.

In averaging the different lactations per cow, the differences due to circumstances which change from lactation to lactation, will tend to cancel each other; thus decreasing the environmental variance, but leaving the genetic variance unchanged.

Gowen (1934) studied the heritability of milk production of Jersey cattle in the island of Jersey. From 738 high producing cows, and 766 low producing ones, using full sisters correlations, the average coefficient was 0.44 for milk yield. When he used half sisters as basis of estimation, the average correlation coefficient was 0.24 . The correlation between full-sibs should contain $\frac{1}{2}$ of the additive genetic variance, while that between half-sibs would be expected to contain $\frac{1}{4}$ of the additive genetic variance. 
When we multiply the correlation coefficient, obtained by the investigator, by 2 in the first case, and by 4 in the second case, we find that the results obtained for the heritability of milk yield, were too high. The author concluded that about $50-70 \%$ of the variation in milk yield was due to heredity, $10 \%$ for environmental causes, and that dominance, assortive mating, and permanent environmental variation, were responsible for the rest of the fluctuations.

Similar data obtained by the same investigator on the HolsteinFriesian and Guernsey breeds, led to similar conclusions. Such results are too high as compared with those obtained by most works in this field.

Copeland (1938) in an attempt to find the best method of using records in evaluating the genotype of the cow made a study of lactations of 197 Jersey cows, which had completed 5 periods of 305-365 days Register of Merit records. He found that the coefficient of correlation between the highest records of the dams and their daughters was $0.29 \pm 0.047$, while that between the averages amounted to $0.30 \pm 0.046$.

Johansson, and Hansson (1940) investigated the relative importance of genetic and non-genetic factors in 3000 Swedish Red\&-White cows, over a period of 15 years, covering 7000 milk and fat records. Using dam-daughter comparisons, it was concluded that the genetic portion of the variation in individual records for milk yield amounted to $30-40 \%$.

The method used in this study, (dam-daughter comparison), is generally the most useful approach, if environmental correlations can be adequately discounted. The major pitfall is the difficulty of appraising correctly the environmental contributions to the observed resemblances between relatives. That is why one should expect such results to be higher than the real heritability value of milk yield. As the period of study was spread out over a long time, this offered a chance for seasons when conditions were unusually good, to cancel the effects of seasons when conditions were unusually bad, and thus lessened a part of the effect that would contribute to the variation.

Lush et al (1941) made two studies; the first study included 676 dam-daughter pairs within 103 sires of the Holstein Friesian herd at Iowa State College, and the second study was of the Holstein Friesian Herd improvement Registery Year Book, and included 209 sires with 6 daughter-dam pairs for each. Using the method of dam-daughter comparison as a criterion to estimate the heritability of milk yield, they came to the conclusion that $25-30 \%$ of the variation was due to heredity, and $57-60 \%$. was due to environmental factors. They gave $15 \%$ of the variation to permanent but non-transmissible differences between cows.

The given measure of $h^{2}$ in this investigation is in accord with most of the results obtained by different workers, inspite of the small number of dam-daughter pairs that was used within each sire.

Johansson (1942) in his investigation with 700 dam-daughter pairs from the Ayrshire cattle in Finland, used intra sire correlations to conclude that $30-40 \%$ of the variation in milk yield was due to heredity. 
Lush, and Strauss (1942) stated that Ward (1940-41) from 3076 daughter-dam pairs within 104 sires, found that the intra-sire regression of daughter on dam for milk yield, was about 0.15 . He used the life time average as a criterion of comparison. This would have lessened to some degree, the effect of the circumstances which change from one lactation to another for the same cow.

Rice (1944) with 19885 Ayrshire, and 23706 Holstein Friesian daughter-dam pairs, showed the following results: $0.289 \pm 0.017$ and $0.322 \pm 0.015$ for average correlation of daughter-dam Ayrshire and Holstein Friesian breeds respectively; and 0.291 and 0.333 for the average regression coefficients in the same respect.

Tyler and Hyatt (1947) converted the milk records of 6888 daughters and mates of 374 Ayrshire sires, to a 305-day mature equivalent twice-a-day milking basis. Twice the intra-sire regression of daughter's production performance on dam's performance, was used to estimate the heritability of milk yield which was found to be $31 \%$. The result obtained is about half the heritability value that was obtained in the same breed by Rice (1944). This gives evidence that the $\mathrm{h} 2$ fraction can easily be changed with the conditions of the material, and the way it is treated with.

Bonnier, and Hanson (1948) from analysis of variance, based on comparisons of milk calories of 6 pairs of identical twins of cattle, estimated the heritability of milk yield as $39 \%$ as calculated from the first lactation, and $91 \%$ as calculated from the second lactation. The authors attributed $12 \%$ of the variation in milk:yield in the first period to environment, and $49 \%$ to interaction + error; while the corresponding values in the second lactation were $4 \%$ and $5 \%$ only.

In this experiment, all animals after first calving had been normally fed with regard to individual weights and yields. In an earlier investigation one group of the twin sisters was undernourished prior to calving, and after calving had used relatively more food for their residual growing power. For that purpose, they yielded less milk than their sisters, during the first lactation. As the average weight difference between the two sister groups became less during the second lactation than during the first, the difference in milk yield was also less during the second period than during the first. Consequently the estimate of the hereditary part of the variance increased greatly from the first to the second lactation. At any rate, the estimate obtained for the part played by heredity in milk yield, was too high in this experiment.

Laben (1950) analysed the normal lactation records for 270 daughter-dam pairs, within 34 Holstein Friesian sires, at the Univ. of Missouri, for the period 1902-1950. The heritability estimate of milk yield as derived from intra-sire regression of daughter on dam, was 0.36 . The effect of mild inbreeding was also analysed, and a significant decline of $66 \mathrm{~L}$. b. milk was observed for each $1 \%$ increase in inbreeding.

Midtlid and Berge (1950) in their study with 992 dam-daughter 
pairs of the Norwegian Red Poll breed of cattle, registered in the herd book volumes 1-10 at Norway, used intra-sire correlations and regressions, to measure the inheritable part of the variance in milk yield. The heritability of milk yield was 0.34 .

Sikka (1950) using the means of all age corrected 2392 lactations of 5 Scottish Ayrshire herds, registered from 1920 to 1939, obtained the value of $37.2 \%$ as the heritability of milk yield. He used Dam-daughter correlation method as a criterion to get his estimate.

Chandrashaker (1951) studied the genetic contribution to the economic characteristics of 396 cows coming from 5 dairy breeds, registered in 1919-1950 in the Michigan State College herd. From 271 daughter-dam comparisons, the heritability of milk yield was $-0.01 \pm 0.08$.

The given result was based on a very limited number of cases from 5 different breeds, distributed over a long period, where the conditions must have differed widely; and it is a great risk to get an average reliable $\mathrm{h}^{2}$ with such limited number of data under those conditions. Mather (1949) concluded that such a negative estimate, which is nearly zero, may be fairly ascribed to sampling error, which was large enough in such a study.

Mahadevan (1951) studied the inheritance of milk yield of 12 leading herds of Ayrshire cattle in S. W. Scotland, with about 5000 milk records collected by means of 14-28 days tests. The daughter-dam comparison method yielded heritability estimate of $0.25-0.30$.

Touchberry (1951) studied the genetics of some characters of 187 daughter-dam Holstein-Friesian pairs, within 22 sires, at the Univ. of Illinois. From daughter-dam comparisons, the average $\mathrm{h}^{2}$ of milk yield was 0.25 .

Vogel, and Werkman (1952) in their study with two bulls from the Black-\&-White cattle in North Holland, estimated the heritability of milk yield. From 31 daughter-dam pairs within the first bull, and 27 within the second bull, they concluded that the heritability of milk yield was $40 \%$.

The given estimate in the last study is a bit high as compared with most of the reliable ones in this field. The investigation was confined to only two bulls which had a large number of daughters. Doubtless that increased the cases where some of the daughters of one bull, and their dams, were kept in one herd, while others of the same bull were kept in another where the management differed. This would have contributed an environmental portion to the daugher-dam correlation. Again, if it happened that an owner had given a daughter and her dam, a better environment than the average of the other pairs in another herd, this would also have added a primary correlation between the environments of the daughter and her dam, which would have contributed a non-genetic portion to the estimate of heritability. It was better in such a study to increase the number of bulls, with even a smaller number of daughters for each, than to choose only two bulls with a rather high number of daughters.

The above results, except that of Chandrashaker (1951) indicated an estimate of heritability of milk yield, that ranged from $25 \%$ 
to $91 \%$. Most of the reliable studies gave values of $25-40 \%$ for $\mathrm{h} 2$ of milk production. We can conclude that phenotypic selection alone should therefore automatically bring about some genetic improvement in the course of milk yield. However, this improvement in the case of that trait, will not be so intense as when the selection is based on the genotypes of the animals.

\section{B. Fat percentage:}

Axelsson (1933) working with dam-daughter correlation method, estimated the heritability of fat percentage in the Lowland cattle at Malmöhus Län. The results showed an average correlation coefficient of $0.386 \pm 0.0381$.

The same investigator (1934) in proving twelve sires from the Swedish Friesian breed, investigated the part played by heredity in the variation of fat percentage. Basing his results on damdaughter correlation, the average correlation coefficient within sires was $0.320 \pm 0.045$.

Bartlett et al (1934) in the course of their investigation, compared 2088 dam-daughter pairs of Holstein Friesian cows within 118 sires, with regard to butter-fat percentage. A significant correlation between dam and daughter was shown to be 0.4169 \pm 0.0122 .

Gowen (1934) in his investigation on the influence of inheritance on butter-fat percentage of 738 high yielding, and 766 low yielding Jersey cows, using the full sister correlation method obtained a correlation coefficient of 0.45 . The half sister correlation gave a coefficient of 0.26 . From that material, and from similar data obtained on the Holstein-Friesian and Guernsey breeds, he concluded that $75-80 \%$ of the variation in fat percentage was due to hereditary causes. He attributed small part of the variation to environment, dominance, and other causes rather than heredity action. His results are nearly in agreement with most of the estimates done in this field by different investigators with different breeds, and under different conditions. This strengthens the idea that fat percentage, in contrast to milk yield, is a very highly heritable character.

Szczekin-Krotow (1938) used the value of $(2 \times$ daughter's\% dam's\%) as an index of fat percentage to 47 Holstein Friesian bulls, gathered from breeders Asociations in Holland. Comparing $210 \mathrm{cow}^{\prime} \mathrm{s}$ index with their 232 daughters coming from the 47 bulls, they measured the part played by heredity in fat percentage as 0.6644 . Selected data of both parents who had $3.5 \%$ fat in their milk, gave the value of 0.635 . The investigators said that the variation of fat percentage was found to correspond to variations caused by random distribution of 4 pairs of genes in a given population.

Johansson and Hansson (1940) estimated the heritability of fat percentage in 3000 Swedish Red-\&-White cows, over a period of 15 years. The genetic portion of variance measured by damdaughter comparisons was $70-80 \%$.

Lush et al (1941) from 3010 daughter-dam's records compari- 
sons, within 209 Holstein-Friesian bulls, concluded that the average heritability of fat percentage was $60 \%$.

Johansson (1942) in his investigation of 700 daughter-dam pairs from the Ayrshire breed of cattle in Finland, used the intra-sire correlation method as a criterion in estimating the heritability of fat percentage. The average result was $70-80 \%$.

Rice (1944) based his investigation on dam-daughter comparisons of 19885 Ayrshire pairs and 23706 Holstein Friesian pairs of cattle in America. Using dam-daughter correlations, he got the coefficients of $0.482 \pm 0.014$, and $0.433 \pm 0.013$ for the Ayrshire and Holstein Friesian respectively. When he used the method of regression of daughter's fat percentage on dam's fat percentage, the two coefficients were 0.474 and 0.436 in the same respect.

Johansson (1947) from a statistical analysis of the first records of 229 pairs, and working with correlation between dam's fat percentage records, and daughter's records from the Swedish Polled cattle, found the heritability of fat percentage to be 70$80 \%$.

Tyler and Hyatt (1947) estimated the heritable fraction in fat percentage, from 6888 daughters and mates of 374 Ayrshire sires. Basing the calculations on intra-sire regression of daughter on dam, the heritability estimate was $55 \%$. They concluded that about $85 \%$ of the animal's genotype that influences milk production, also influences the production of butterfat. They also suggested that approximately $20 \%$ of the heredity that influences milk yield, also affects the fat percentage in the milk. The results of this study indicated that fat percentage was about twice as heritable as milk yield as well as butterfat production.

Johansson (1949) from a study of intra-sire correlations with 20 high producing, and 13 low producing herds of the Swedish Red$\&-$ White cattle, estimated the heritability of fat percentage as $70 \%$.

Laben (1950) analysed the records of 270 daughter-dam pairs within 34 Holstein-Friesian sires, at the Univ. of Missouri. The heritability estimate as derived from intra-sire regression of daughter on dam was 0.54 . Genetic correlation showed that a decline in fat percentage was accompanied by increase in milk production. The correlation between lifetime average of milk yield and fat percentage was -0.10 .

Midtlid, and Berge (1950) from their study of the Norwegian Red Poll cattle, used the regression of 992 daughter's fat percentage records, on their dams' records, to measure the inheritable part of variance in fat percentage. The average heritability was 0.66 .

Chandrashaker (1951) studied the genetic contribution to fat percentage in 5 dairy breeds at Michigan State College. Basing the calculations on intra-sire 271 daughter-dam comparisons, the average heritability of fat percentage was $0.56 \pm 0.05$.

It is worth while here to mention that the $h^{2}$ estimate obtained in the last study, was obtained by the same investigator, and from the same limited material that yielded a negative value or nearly zero estimate of the heritability of milk production. That gives a new evidence that the fat percentage is highly heritable and is 
much less affected by the non-genetic circumstances that affect the milk yield.

$\because$ Mahadevan (1951) from analysis of about 5000 fat records from Ayrshire cattle in S.W. Scotland, reported that the heritability of fat percentage was between 0.50 to 0.60 . The data were collected from different herds, and were analysed by using dam-daughter comparison as a method to estimate $\mathrm{h}^{2}$ of the character.

$\because$ The above results gave estimates of heritability of fat percentage ranging between 0.50 and 0.90 . These high estimates make it posisible to obtain better understanding of the individual genotype, with regard to fat percentage, through the practice of phenotypic selection. The breeder: can have: much control on the heredity of that character, in the exercise of improvement.

\section{Fat yiel-d:}

Gifford, and Warren (1930) studied the inheritance of yearly :butter-fat production: in advanced registry records of 2041 damdaughter pairs of cattle, from the Holstein-Friesian advanced register year books. Using dam-daughter comparisons in groups according to the sires average performance, the average coefficient of correlation was 0.197 . This means that the heritability of that character was $39.4 \%$.

Heizer (1933) . reported an estimate of heritability of 0.778 \pm 0.013 for butter-fat production as calculated from correlations between dams and daughters within sires, in the Ayrshire cattle in Philadelphia herd. This estimate is about double that given by Gifford \& Warren (1930) for the h2 of the same trait.

Plum (1935) studied. the causes of differences in butter-fat production of, 95 herds of Guernsey, Holstein-Friesian, and Jersey breeds of cattle, found in Iowa cow testing associations. Using 'dam-daughter comparisons as a basis of the analysis, and from a total number of 5859 degrees of freedom, he concluded that the part played by genetics in the heredity of butter-fat production amounted to $26 \%$. He attributed the rest of the variation to the environmental causes, and only $2 \%$ to the breed differences.

Johansson; and Hansson (1940) in their study of 3000 Swedish Red-\&-White cows, over a period of 15 years, covering 7000 records, and with the aid of dam-daughter correlation method, concluded that the genetic portion of variation in individual fat production record a mounted to $30-40 \%$.

This estimate means that the character is only heritable to the same degree as milk yield is.

Lush, and Strauss (1942) worked out the intra-sire correlation and regression of daughters on dams separately in different breeds of cattle from Iowa Herd improvement associations, registered from different herds during the period 1936-1939. A sum of 283 sires with an average number of 7.6 daughter-dam comparisons per sire were included to get the following results for pounds of fat produced in the first 305 days of corrected lactations: 0.130 and 0.133 for Holstein, 0.147 and 0.147 for Guernsey, 0.166 and 0.157 for Jersey, 0.076 and 0.085 for Brown-Swiss, 0.270 and 
0.208 for Ayrshire, 0.046 and 0.045 for Shorthorn, and 0.084 and 0.051 for Red Polled cattle, for their dam-daughter correlation and daughter on dam regression coefficient, respectively.

The investigators attributed the causes of differences in these estimates done on different breeds, to mainly two reasons; 1 . a sampling variation. 2 . The breed differences. It was also found in the breeds in which the dams' records averaged the highest, the daughters' averages went yet higher, while in the breeds in which the dams' records averaged lowest, the daughters' averages went yet lower. Why this was so, the investigators did not know, but its effect on the variance between breed averages was obvious from the results obtained.

Johansson (1947) from a statistical analysis of the milk records of 462 dam-daughter pairs from 29 herds of Swedish Polled cattle, calculated the coefficients of intra-cow correlation, and daughter on dam regression within bulls. Those calculations indicated an estimate of heritability of fat yield as the order of 30$40 \%$.

Tyler, and Hyatt (1947) corrected the production of 6888 daughters and mates of 374 Ayrshire sires, in order to estimate the heritability of butter-fat yield. Using intra-sire regression of daughter on dam, the heritability estimate of the trait was $28 \%$. They concluded that about $85 \%$ of the animal's genotype that influences milk production, also influences the production of butterfat.

Johansson (1949) reported from a study with 20 high producing, and 13 low producing herds of Swedish Red-\&-White cattle, a heritability estimate of $36 \%$ for fat yield.

Legates (1949) studied the butterfat production from 23330 records of 12405 cows coming from 293 different Jersey herds at Iowa State. When heritability was computed as twice the intraherd regression of daughter-on-dam, on a single record basis, the estimate of $h^{2}$ of butter-fat production was 0.201 . This value is to a some degree less than most of the results obtained in this field and for the same character. The sampling error would have played a part in reaching this result.

Beardsley et al (1950) in a study with progeny records of 176 proved sires of the Guernsey, Holstein-Friesian, and Jersey breeds, which were represented by 5 daughter-dam comparisons in each, and from 2 or more herds, calculated the heritability of butter fat yield. By doubling the linear regression of daughter on dam within breeds, within sires, and within herds, the estimate was $27.4 \%$.

Laben (1950) analysed the normal fat yield records of 270 daughter-dam pairs within 34 Holstein-Friesian sires, at the Univ. of Missouri, over the period 1902-1950. The heritability estimate of fat yield as derived from intra-sire daughter on dam regression, was 0.29 .

Midtlid and Berge (1950) from 992 pairs intra-sire daughter on dam regression from the Norwegian Red Poll cattle registered in the herd book volumes 1-10 at Norway, found that the heritability of fat yield was 0.44 .

Chandrashaker (1951) from the records of 396 cows of 5 breeds 
of dairy cattle at Michigan State College, registered from 1919 to 1950, used 271 daughter-dam comparisons to estimate the heritability of fat yield as $0.20 \pm 0.08$. The estimate is a little lower than most of the other $\mathrm{h}^{2}$ values given by different investigators, and could be attributed to the sampling error.

Rennie (1951) working with Jersey cattle at Canada, analysed the records of 776 dams with 858.daughters, from 360 sires. By the aid of daughter-dam comparisons within sires, he found that the heritability of fat production was $36 \%$.

Touchberry (1951) studied the genetics of some characters of the Holstein cows at the Univ. of Illinois. From 187 dam-daughter comparisons within 22 sires, the heritability of fat yield was 0.35 .

The same investigator, working on the same material had given the value of $0.25 \mathrm{as}^{\prime}$ the heritability of milk yield. As $\mathrm{h}^{2}$ of fat percentage proved always to be much higher than that, and as the fat yield is the net result of multiplication of fat percentage and milk yield, one should always expect that the heritability of fat yield would be a little higher than that of milk yield, as was the case in the former study.

Harvey, and Lush (1952) from a study of 2786 daughter-dam pairs of Jersey breed, collected from 226 herds over a period of 1943-47, measured that additively genetic variation constituted about $18 \%$ of the intra-herd and intra-year variance in single record of fat yield.

Most of the above mentioned results indicate an estimation for the heritability of fat production that was around 0.35 . The estimates more or less agree with those given as heritability values of milk yield. It can be fairly concluded that the character is highly affected by the non-heritable factors, to about the same degree as the milk yield is.

\section{Other characters concerning milking abilities}

Johansson, and Hansson (1940) in their investigation with 3000 Swedish Red-\&-White cows, concluded that the genetic portion of the variation in persistency was $15-30 \%$.

Johansson (1942) made a study of 700 daughter-dam comparisons from the Ayrshire cattle in Finland. He computed that the heritability of length of milking period was $15-30 \%$.

The same investigator (1947) from a statistical analysis of the records of 462 daughter-dam pairs of cows from 29 herds of Swedish Polled cattle, calculated the coefficient of daughter-on dam regression within sires, to obtain $20-30 \%$ as the heritability value of persistency of yield.

In (1949) from his study with 20 high producing and 13 low producing herds of Swedish Red-\&-White cattle, Johansson reported $22 \%$ for the heritability of persistency and $32 \%$ for $h^{2}$ of length of dry period.

Sikka (1950) from his 2392 lactations study of 5 herds of Scottish Ayrshire cattle, concluded that the heritability of persistency was $29.2 \%$. 
Mahadevan (1951) from his study with about 5000 milk records in Scotland, declared that the heritability of persistency of milk yield was between 0.10 to 0.15 .

Johansson, and Korkman (1952) studied the heritability of the udder properties in 591 cows, the progeny of 62 bulls, in Swedish Red-\&-White, Swedish Friesian, and Swedish Polled breeds of cattle. The results of the statistical analysis indicated that variation in yield between the left and the right half of the udder were of wholly non-genetic origin. The front-to-rear index of heritability was 0.75 . There seemed to be very good prospects of improving symmetry between the fore and rear udder by means of selection.

The previous results show clearly that the heritability estimate of a given character, is not a constant fraction. The different investigators, or even the same investigator gave hereditary estimates for any trait, that differed according to the conditions of the material, and the way it was estimated and treated with. The estimated value of heritability then, is a statistic fraction describing a particular population. Lush (1940) stated that this fraction can be made larger or smaller if either the numerator or the other ingredients in the denominator can be altered. Thus it may vary from population to population for the same characteristic, and may vary from one characteristic to another even in the same population.

The results obtained for heritability estimates, by different investigators, are summarised in the following survey.

\section{Summary of heritability estimates by different investigators on dairy properties}

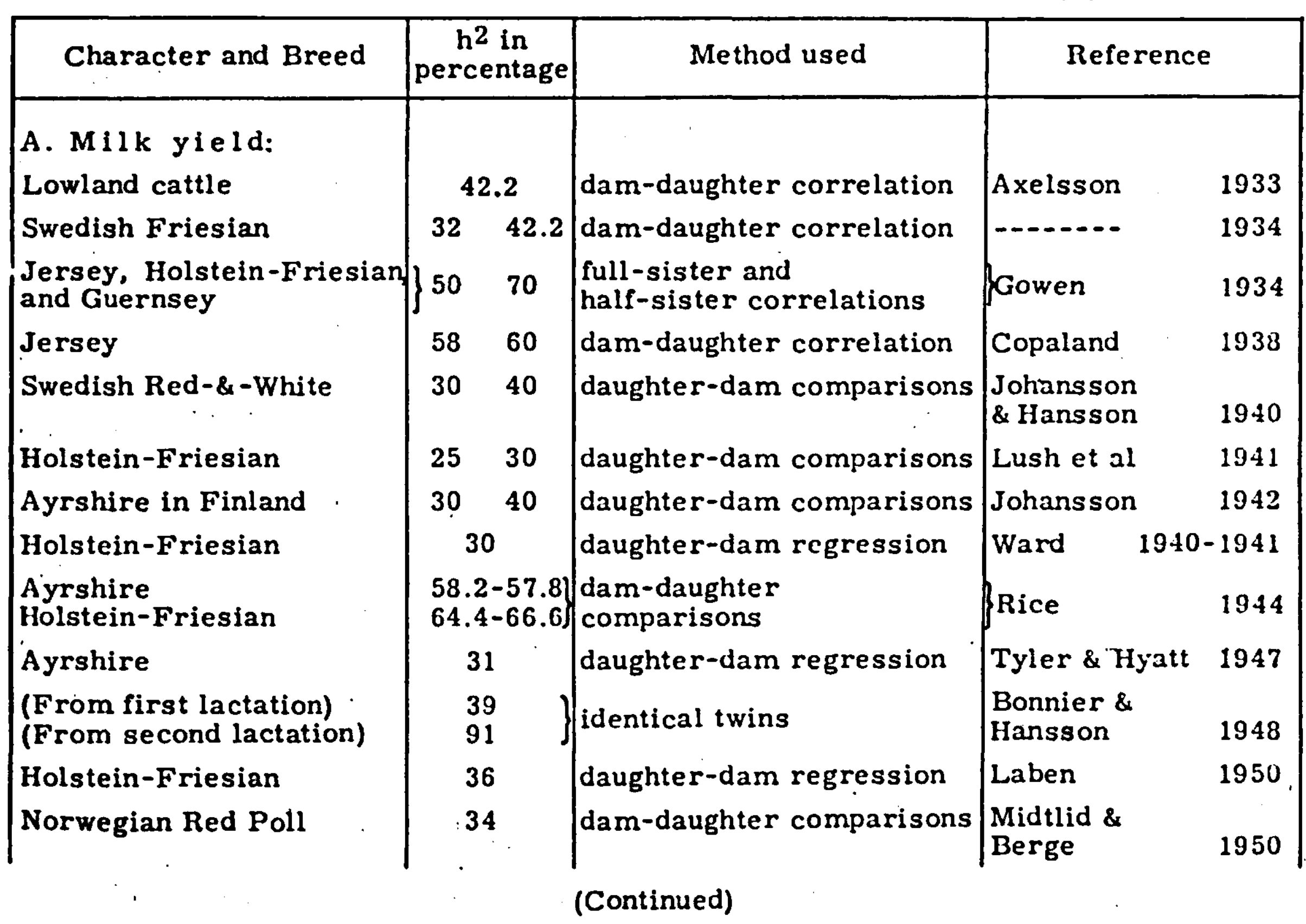




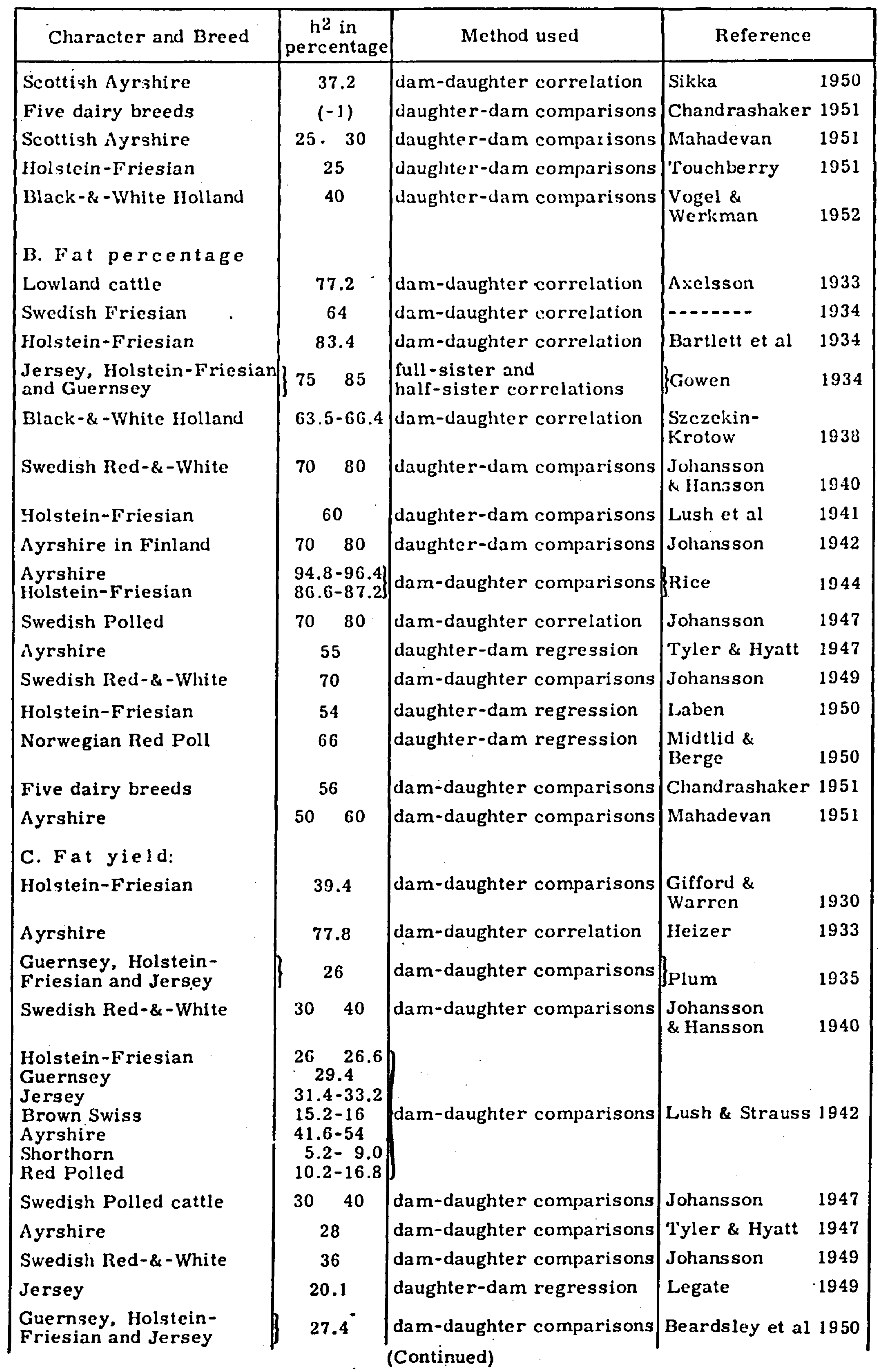




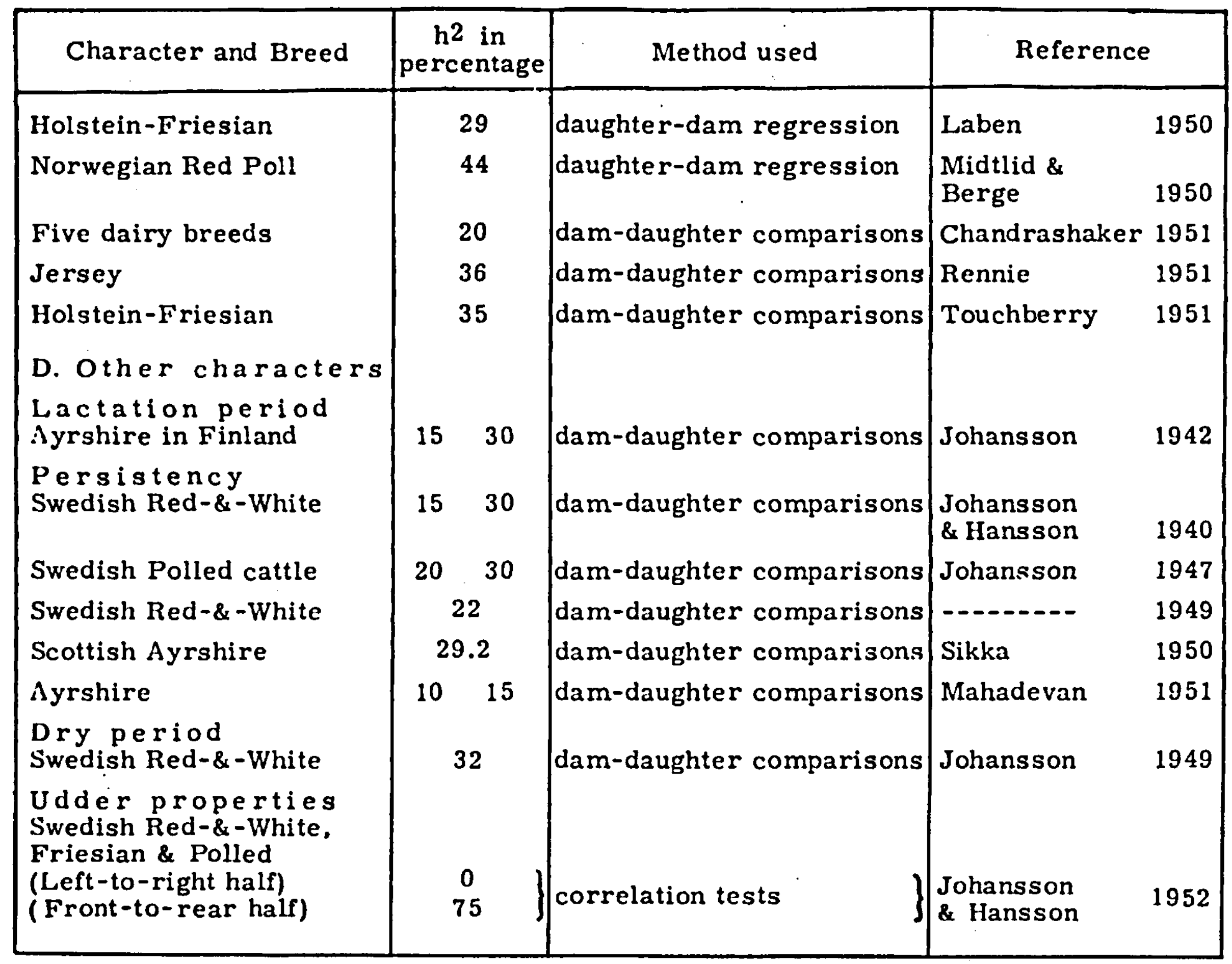


The Friesian Herdbook Society, "Friesch Rundvee-Stamboek", dates back as far as the year 1879. By using primitive means, selection was established centuries ago to improve this breed of cattle, before the foundation of the society. Since, in the last century, no animal was introduced to Friesland, one can say that this breed of cattle is pure Friesian cattle. Figure 2 shows a typical Friesian bull, and figure 3 shows a typical Friesian cow.

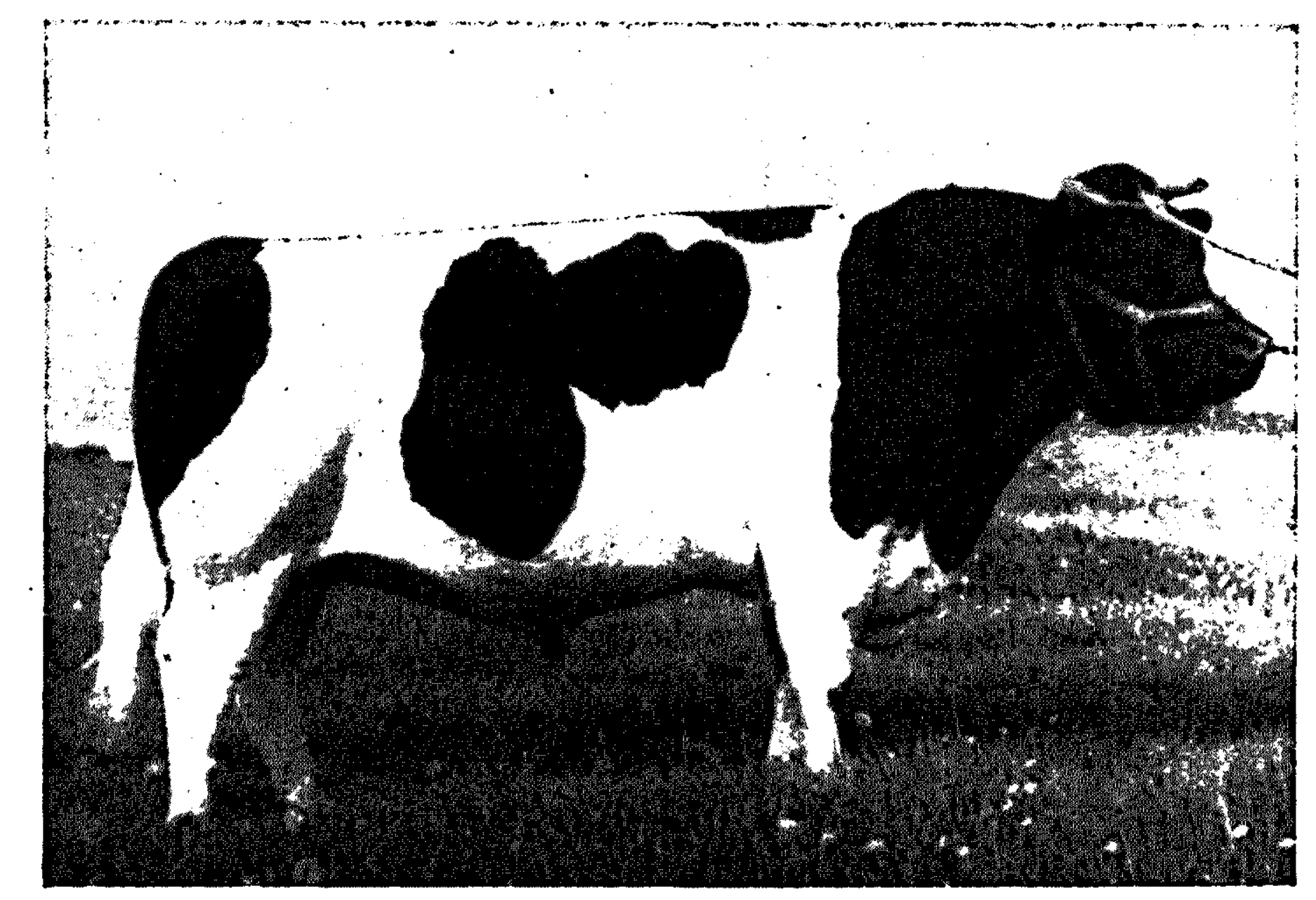

Fig. 2. A typical Friesian bull.

(Anna's Adema 30587 F.R.S.).

It is a common way in this province to breed the heifers at about 15 months of age, so that around the age of two years, cows can have their first calving. The animals over the whole province are milked twice daily at about equal intervals, and a test-milking is carried out every fifteen days. A test-milking always concerns the yield of one cow produced during 24 hours, and includes the yield in the evening of a certain day, together with the quantity yielded the next morning. The milk yields are recorded by people specially appointed for the purpose as certificated recorders, assisted by samplers. They register the records of test-milking in the milk-book of the dairy farmer concerned, as well as in separate milk sheets which are at a later date forwarded to the 
herdbook office, as well as the provincial milk service, for ratification. When the cows are dried off, the final figures are determined as soon as possible.

According to the last report of the central milk control service organisation in 1954,79\% of the Friesian cows in Friesland are under control: All the registered cows are controlled, as a general rule.

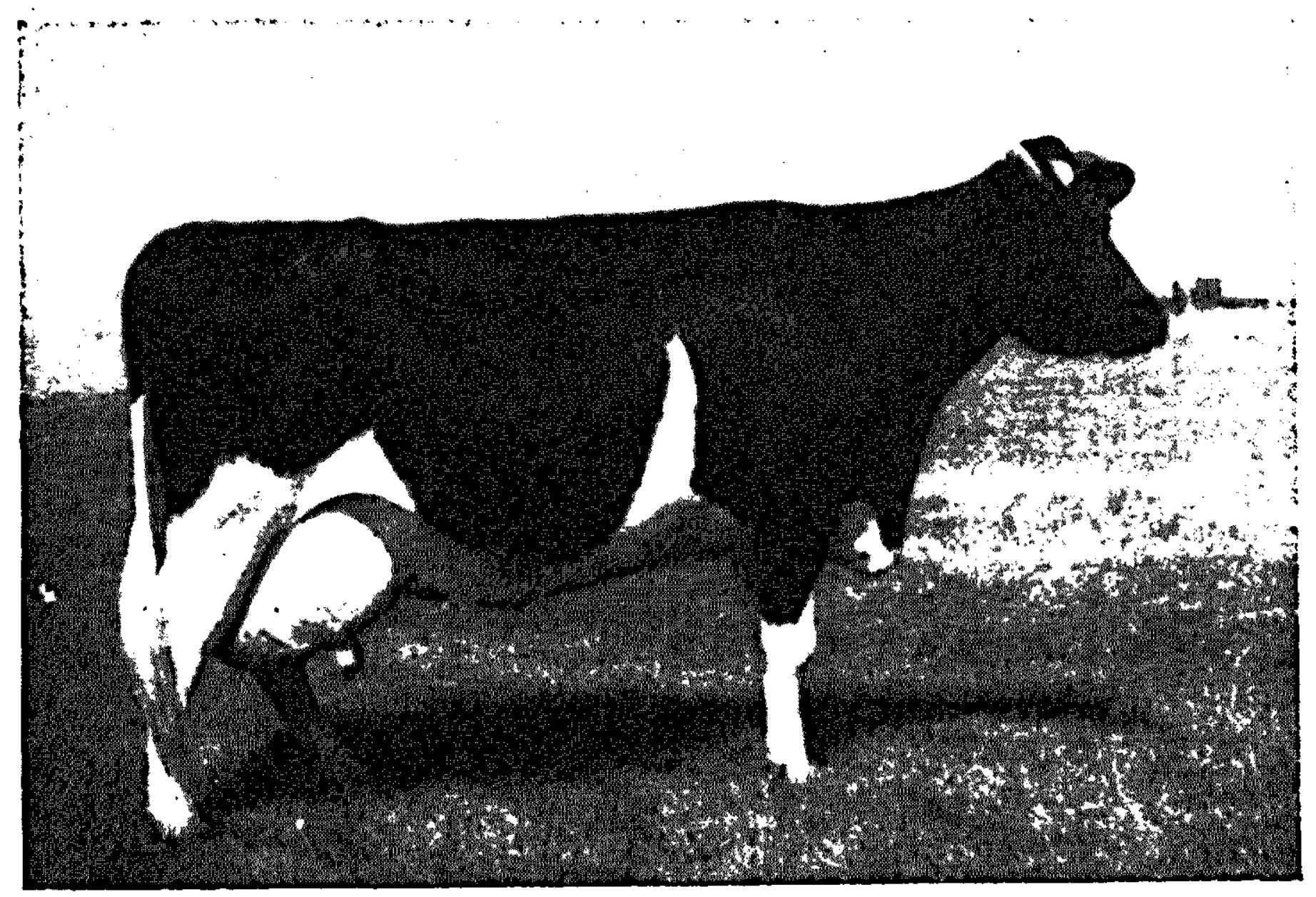

Fig. 3. A typical Friesian cow.

(Sneeker 44143686 F.R.S.).

All the records of the registered cows in Friesland since 1920, were pooled out to serve as a material for this research. Before the year 1920, the production was markedly affected by the conditions of the first world war; where as before that war, the well developed milk control system, was not to rely upon yet. As the main purpose of this research work is to estimate the heritability of milk yield and fat percentage without using correction factors, it was sound to exclude the disturbed period of the second war conditions.

Figure 4, illustrated from printed matter of the "Friesch Rundvee Stamboek", shows clearly the disturbed periods before the first war till 1920, as well as during the period (1940-47) of the second world war.

Soil and Feeding: Cattle spend about half of the year in the open on permanent grassland, which takes up about $85 \%$ of the total of cultivated land in Friesland. During this period, the animals' food consists enclusively of grass. As nothing is cheaper than grass in feeding problems in the Netherlands, most of the production is obtained during this green season.

During the six months of winter time, when the cows are indoors, the ration consists mainly of hay, grass silage, and arti- 
ficially dried grass. These standard rations of roughages are supplemented; (especially on the mixed farms), by beets, beettops, and roots. The total amount of concentrates per milking cow per season, amounts to 200-250 kgs.

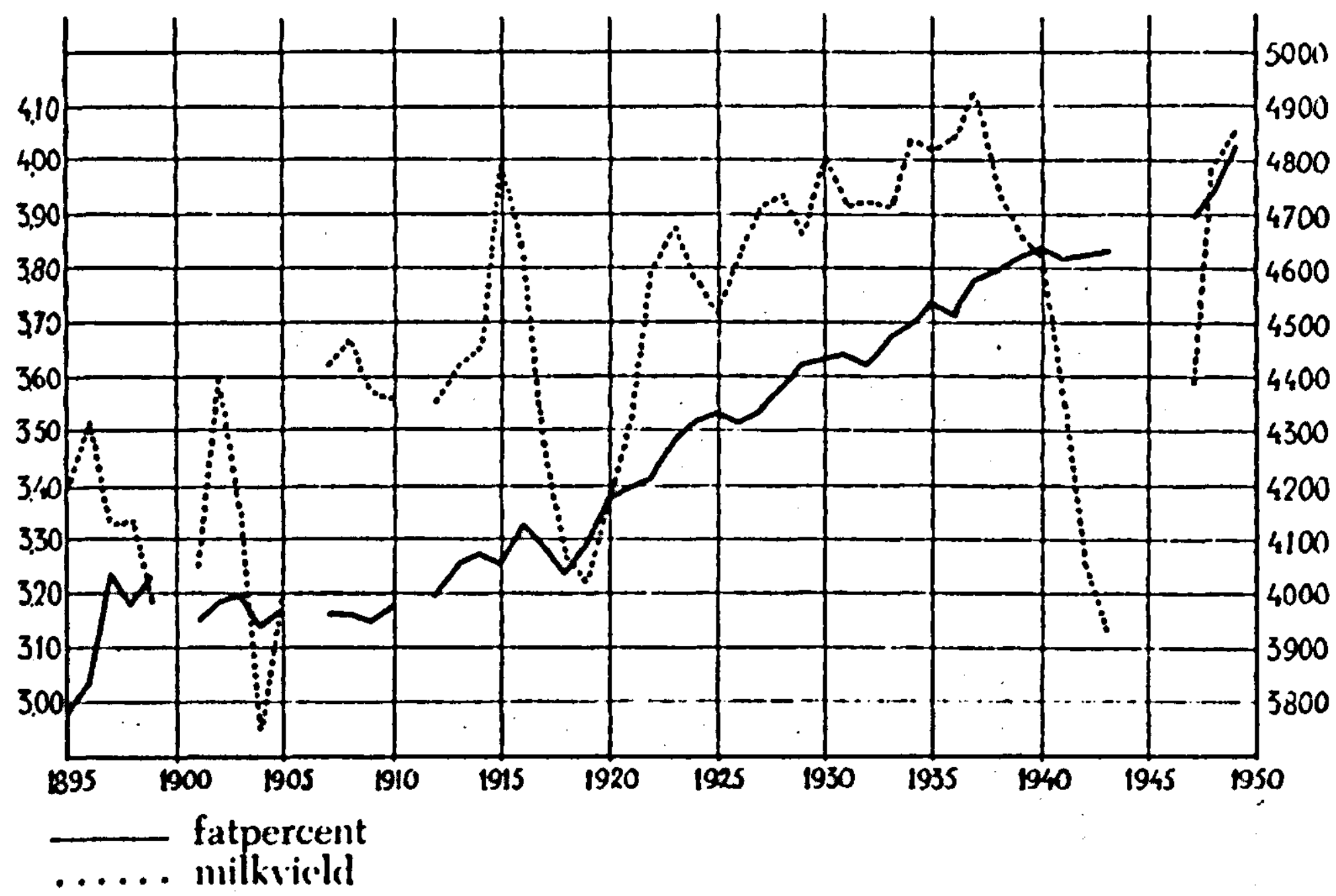

Fig. 4. Average fat percentage and milk yield in $\mathrm{kg}$. , of cows entered into the Friesian Herdbook.

The soils of the province of Friesland are composed of clay, peat, and sand. It is said that the production differs even slightly, according to the kind of soil the animal is reared on. For this purpose, the animals serving this research were grouped according to the kind of soil kept on; and then all were pooled together to see if there is an effect on the heritability estimate from this point of view.

From figures 5, 6, and 7 , we can illustrate the distribution of the daughter-dam pairs included in this research, over the clayey, peaty, and sandy soils, where the animals were kept on.

Conditions of research: Under the following conditions, a total number of 9550 pairs of daughter-dam records were introduced in the comparisons, firstly for correlations, and secondly for regressions, in order to estimate the heritability of milk yield. An equal corresponding number was used in the calculations for $\mathrm{h}^{2}$ of fat percentage. These comparisons covered the first three lactation periods. The daughter-dam pairs introduced in each case were distributed on the three lactation periods as follows: 4315 daughter-dam pairs within 117 bulls for the first period, 3402 daughter-dam pairs within 104 sires for the second lactation period, and 1833 daughter-dam pairs within 65 bulls for the third production period. 


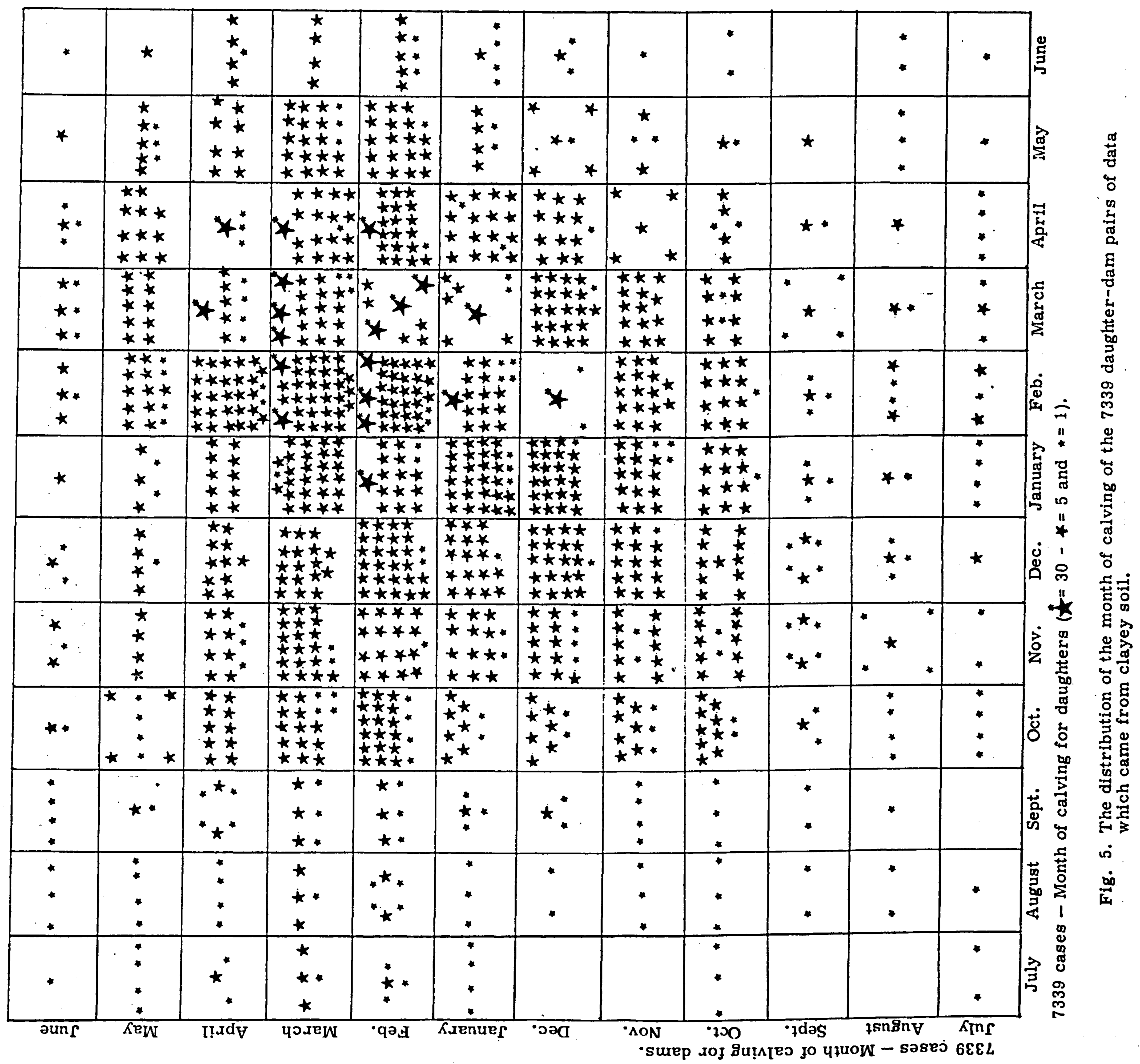




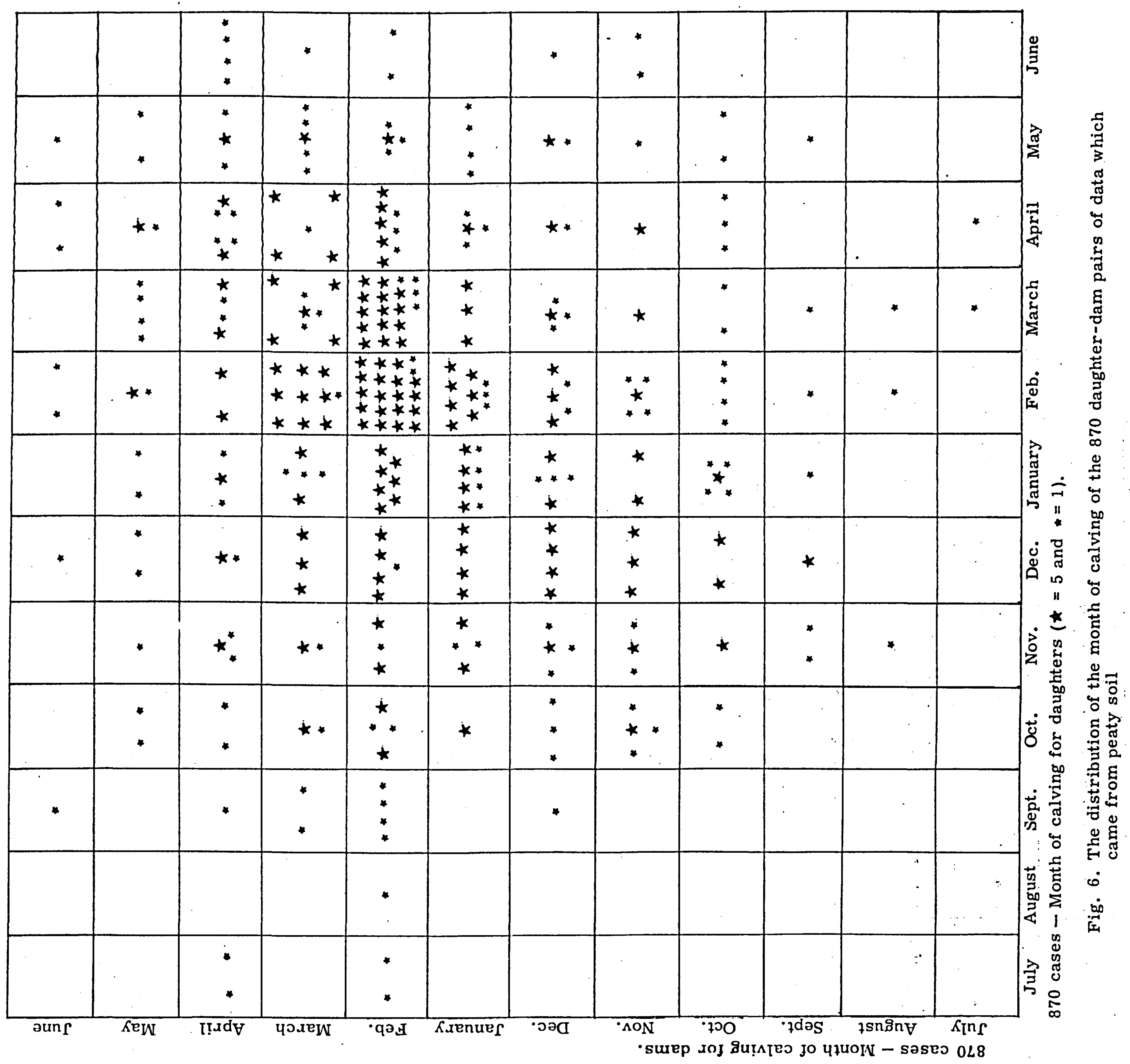




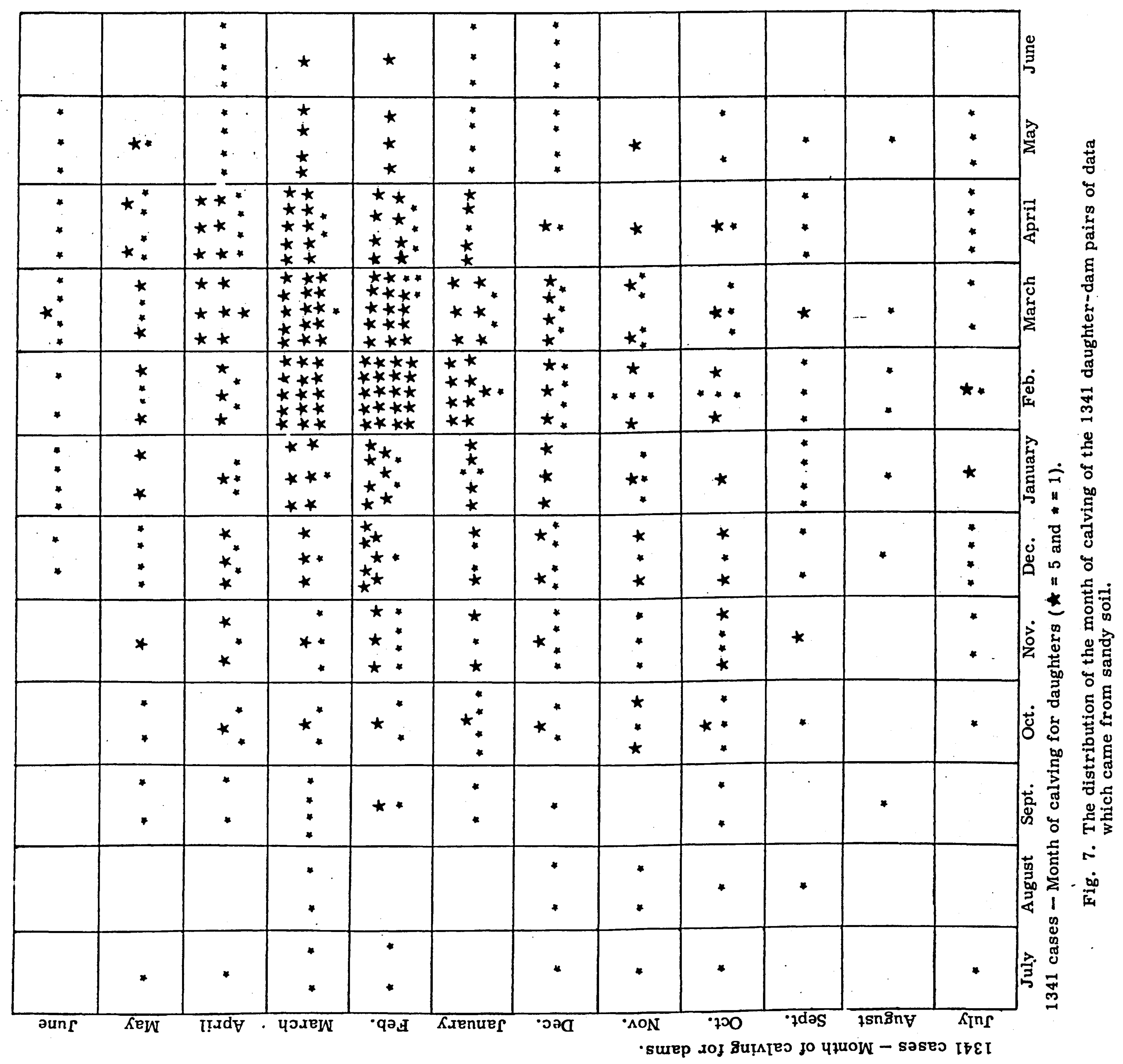


The average number of pairs in each comparison within sire, was 36.9 daughter-dam pairs, with a minimum number of 15 , and a maximum of 84 pairs for the first period, with respective numbers of 31.8 pairs, and 15-73 for the second period, and 28.2 daughter-dam pairs, and 15-55 for the third production period, in the same respect.

\section{Conditions}

1. As was stated before, the two periods of producing during war, were neglected for the purpose of unfavourable conditions of feeding that affected the production, as shown in figure 4. 2. The average milk yield per day, as calculated from normal lactations, with periods lying between 260. to 360 days, was taken as a criterion in the comparisons for measuring the heritability of milk yield in this study. In order to estimate $\mathrm{h} 2$ of fat percentage, only records coming correspondingly with the lactations included, were worked out.

3. The minimum number of pairs within sire in any of the comparisons was not less than 15 , while the maximum was 84 .

4. The bulls that served this study: were only used on normal services, and no sire group of the artificial insemination was introduced.

5. Mostly the daughter-dam pair under comparison was kept in one herd during the production studied.

6. In each case under comparison, only a difference in age not more than six months between the daughter and her dam, was allowed. Fortunately, it seemed that mostly ali the cattle females in the province of Friesland were bred when they were around the age of 15 months.

7. The groups within each sire were divided into three categories owing to the kind of soil the animals were kept on. In this way, the attempt was made to minimise the effect of different feeding conditions on the three different soils. If a sire's group was kept on different soils, the group was divided into subgroups, and each was worked out separately.

8. Assuming homogeneous population, rather than intra-sire basis, the pooled regressions and correlations were worked out, neglecting the part played by sires, and depending only on the side of the dams. In this way, the heritability estimates were first worked out according to groups within each kind of soil. In a second attempt, the intra-breed estimates were measured, neglecting the effect of different kinds of soil.

9. From figures 5,6 , and 7 , it is easy to conclude, in most cases, the striking similarity between the month of calving of each dam-daughter pair under comparison in this research. 


\section{METHODS USED}

The analysis of covariance was used to obtain the regression and correlation coefficients in the present investigation. The heritability reached at was computed firstly by doubling the intrasire, intra group, and intra breed, dam-daughter correlation coefficients; and secondly by doubling the corresponding daughterdam regression coefficients, for milk yield, as well as for fat percentage.

As devised by Fisher (1954), the conceptions for calculating the correlation coefficient $(r)$, the regression coefficient (b) and for the standard error of the correlation, are as follows:

$$
r=\frac{\Sigma(x y)}{\sqrt{\Sigma\left(x^{2}\right) \cdot \sum\left(y^{2}\right)}},
$$

where " $r$ " is the product correlation between " $X$ " and " $Y$ " variates.

$$
\mathrm{b}=\frac{\Sigma(\mathrm{xy})}{\Sigma\left(\mathrm{x}^{2}\right)} \text {, }
$$

where " $b$ " is the regression coefficient of daughter's records on dam's records, and " $x$ " and " $y$ " were used to represent dam and daughter deviations, respectively.

Fisher (1954) in discussing the accuracy of the correlation coefficient, stated that with large samples, and moderate or small correlations, the correlation obtained of " $n$ " pairs of values, is distributed normally about the true value " $\rho "$; (where " $\rho "=$ correlation between $x$ and $y)$, with variance $\frac{\left(1-p^{2}\right)^{2}}{n-1}$; it is therefore usual to attach to an observed value " $r$ " a standard error

The equation

$$
\frac{\left(1-r^{2}\right)}{\sqrt{n-1}} \text { or } \frac{\left(1-r^{2}\right)}{\sqrt{n}}
$$

$$
\sigma_{r}=\frac{1-r^{2}}{\sqrt{\sum(n-1)}}
$$

was used to calculate the figures shown in this investigation as standard error of the correlation within groups.

At the advice of Prof.Dr. N.H. Kuiper, the following equation was used to compute the standard errors of the regression coefficients obtained in the present study: . 


$$
\sigma(b)=\frac{\sigma y}{\sigma x} \sqrt{\frac{1-p^{2}}{\sum(n-1)-2}},
$$

where $\sigma(b)$ is the standard error for the regression coefficient, " $p$ " is the correlation between " $x$ " and " $y$ ", and " $n$ " is the number of pairs included.

The degrees of significance mentioned in the present study for the differences between regression coefficients, were measured according to Snedecor (1946) page 320- table 12.3, and Kenney and Keeping (1953) page 276- table 9.66.

The test of symmetry of the graphs of the frequency curves, was carried out according to Snedecor (1946) p. 174, section 8.5; where the measure of skewness is " $g_{1}$ ". If $g_{1}$ were zero, symmetry in the sample would be demonstrated. 
Chapter V

\author{
RESULTS
}

\title{
A. Milk yield
}

The estimation of the fraction of variance in milk yield which is due to hereditary causes, was based on 117 intra-sire groups, daughter-dam comparisons. From 9550 pairs of data distributed over three lactation periods in the different parts of the province of Friesland, the following results were gained.

Table No. 1 shows the results of the analysis of variance and covariance, for the determination of dam-daughter correlation $(r)$, as well as daughter on dam regression (b).

It. is shown in table 1 that the dam-daughter correlation method yielded the following coefficients: First lactation; for groups reared on clayey soil $0.1740 \pm 0.0172$, for those kept on peaty soil $0.1784 \pm 0.0570$, for the sandy soil groups $0.1958 \pm 0.0465$, and when no soil differentiation was made, the average correlation coefficient was $0.1868 \pm 0.0149$. The respective regression coefficients were $0.1622 \pm 0.0163,0.1755 \pm 0.0591,0.2068 \pm 0.0503$, and $0.1758 \pm 0.0143$, in the same respect.

For the second lactation, and in the same order as mentioned above, the average correlation coefficients were $0.1946 \pm 0.0192$, $0.2152 \pm 0.0623,0.1691 \pm 0.0513$, and $0.2049 \pm 0.0167$; whereas the average regression coefficients were $0.1836 \pm 0.0185,0.2003$ $\pm 0.0595,0.1659 \pm 0.0532$, and $0.1966 \pm 0.0164$

In the third lactation period, the respective values were 0.1885 $\pm 0.0278,0.2673 \pm 0.0817,0.2184 \pm 0.649$, and $0.1858 \pm 0.0229$ for the correlation coefficients, and $0.1839 \pm 0.0276,0.2261$ \pm 0.0723 , $0.2079 \pm 0.0636$, and $0.1746 \pm 0.0220$ for the regression coefficients, in the same respect.

The number of comparisons, in the case of neglecting the effect of soil, was always higher than if it was calculated as a total of the daughter-dam pairs that entered in the groups of different kinds of soil. From the "material", no sire group with less than fifteen pairs was allowed in the comparisons. It happened in some of the cases that a sire group which was kept on different kinds of soil, when divided into sub-groups according to the kind of soil; some of these sub-groups could not suffice for the minimum number of daughter-dam pairs required in the research. Such subgroups could serve the material when we made no differentiation according to the kind of soil the animals were reared on. This. was the cause of the difference found between the total number of comparisons, and the summations in this investigation.

In assuming homogeneous population, the pooled correlation and regression coefficients are shown in table No. 2 . 


\begin{tabular}{|c|c|c|c|c|c|c|c|}
\hline \multirow{8}{*}{ 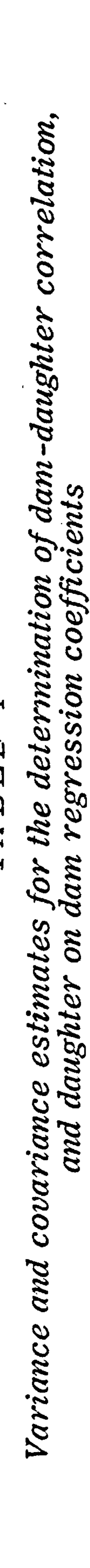 } & $=$ & & 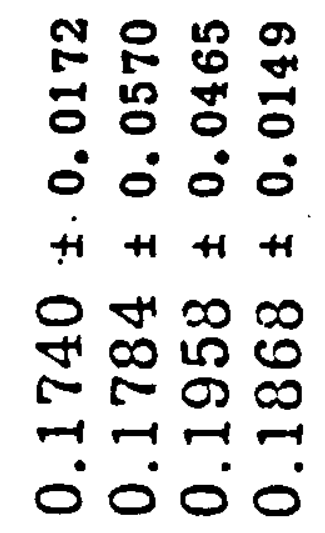 & & 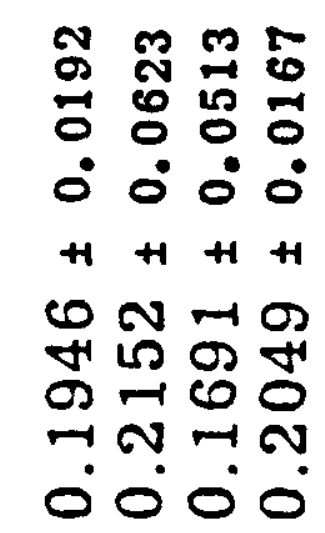 & & 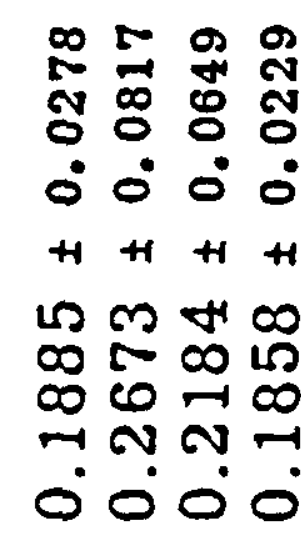 \\
\hline & $\begin{array}{l}\overline{0} \\
\equiv\end{array}$ & & $\begin{array}{l}\mathscr{B} \\
0 \\
0 \\
0\end{array}$ & & 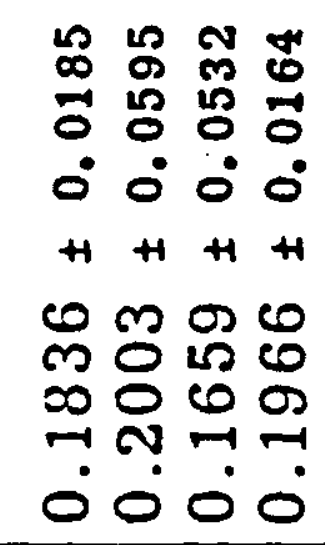 & & 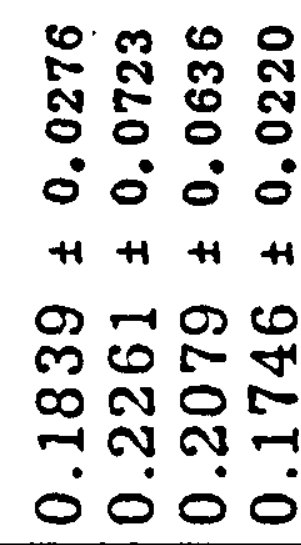 \\
\hline & $\underset{\omega}{\widehat{N}}$ & & 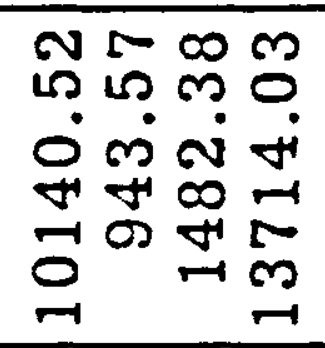 & & 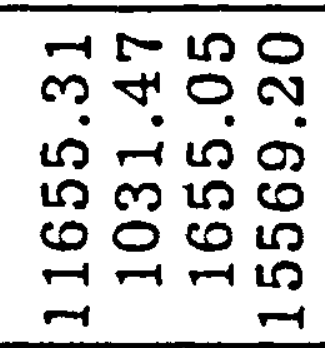 & & 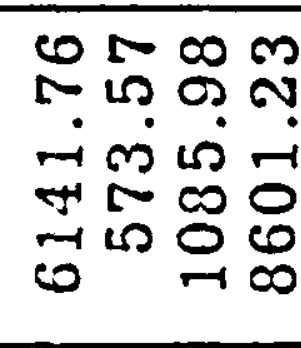 \\
\hline & $\underset{\widetilde{w}}{\widetilde{w}}$ & & 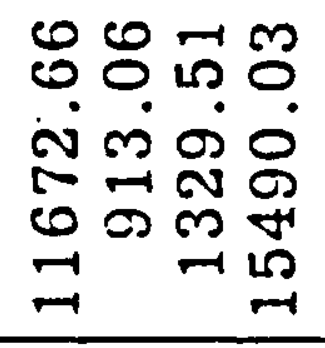 & & 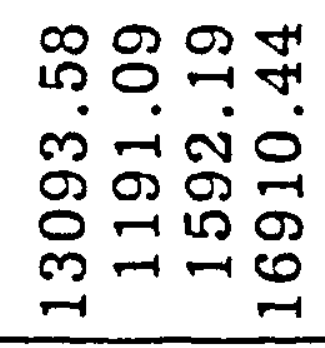 & & 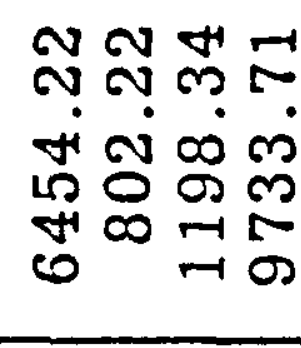 \\
\hline & $\frac{\widehat{\not}}{\omega}$ & & 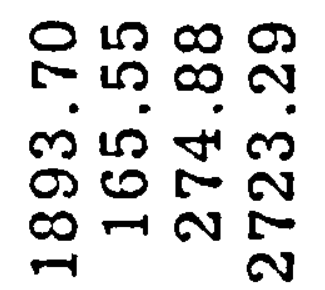 & & 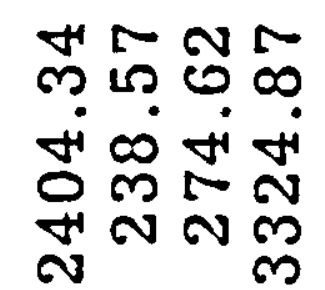 & & 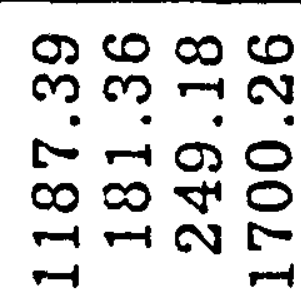 \\
\hline & 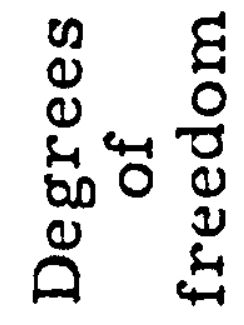 & & 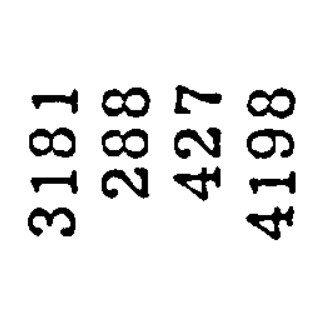 & & 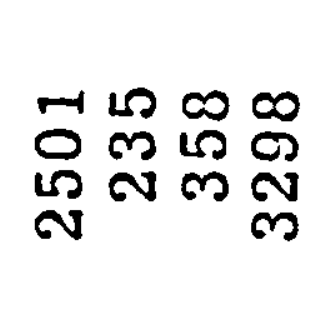 & & 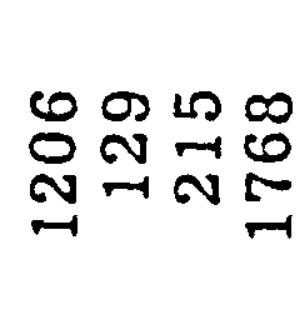 \\
\hline & 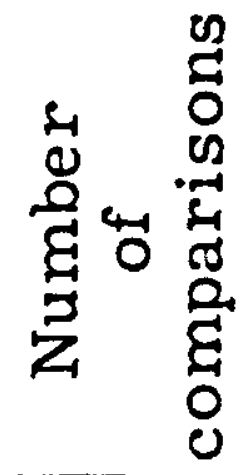 & & 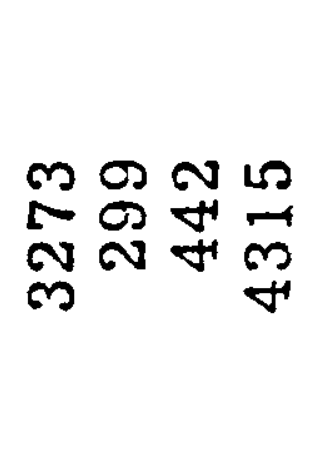 & & 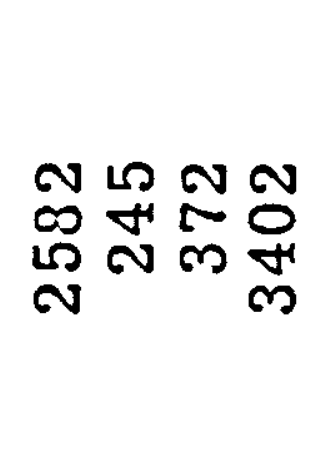 & & 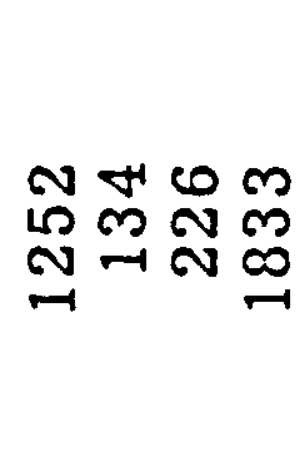 \\
\hline & 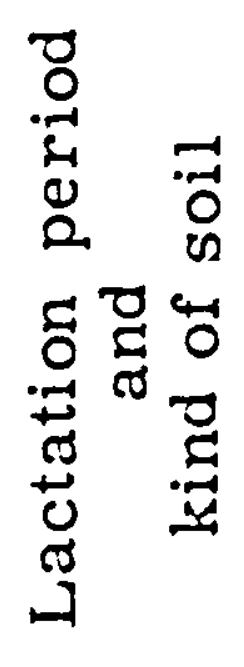 & 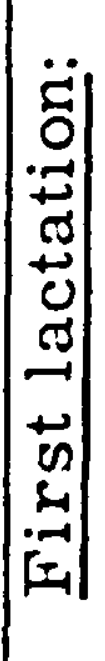 & 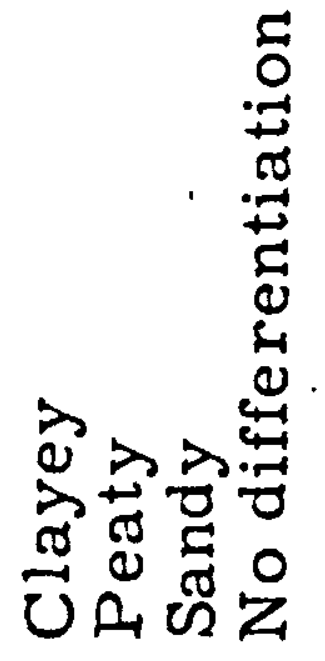 & 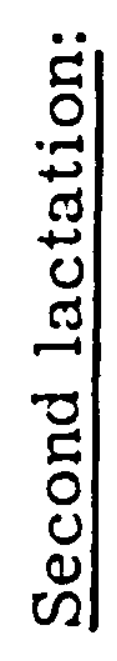 & 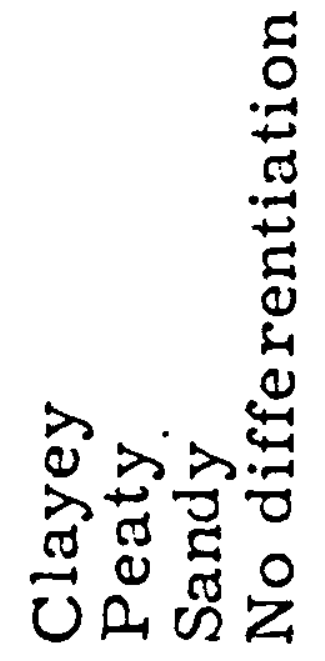 & 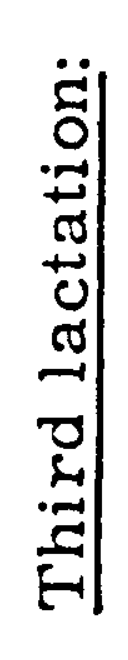 & 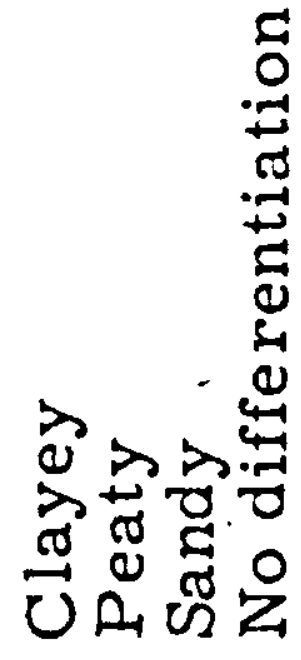 \\
\hline
\end{tabular}




\begin{tabular}{|c|c|c|c|c|c|c|c|c|c|}
\hline \multirow{4}{*}{\multicolumn{2}{|c|}{ 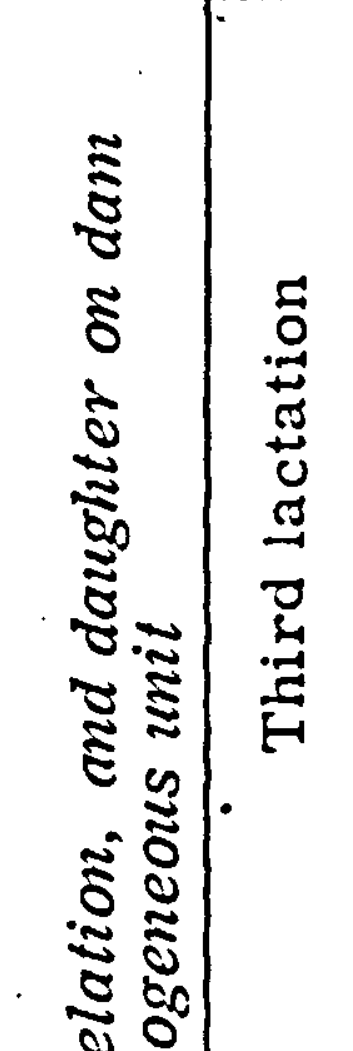 }} & 寻量 & $\begin{array}{l}\infty \\
\infty \\
\infty \\
\infty\end{array}$ & ஸै & 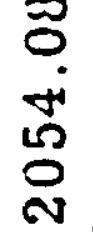 & 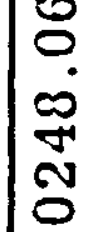 & $\mid \begin{array}{l}0 \\
\infty \\
\vdots \\
\infty \\
0 \\
0\end{array}$ & 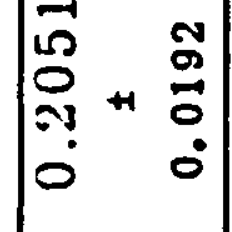 & 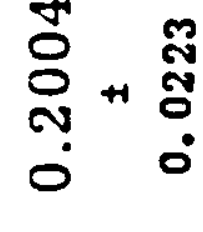 \\
\hline & & 冚 & $\begin{array}{l}\stackrel{0}{N} \\
\text { N }\end{array}$ & $\stackrel{\mathscr{N}}{\text { N }}$ & 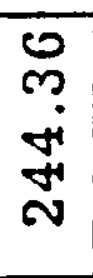 & 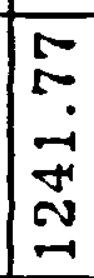 & \begin{tabular}{l}
0 \\
-1 \\
0 \\
10 \\
\hdashline \\
-1
\end{tabular} & 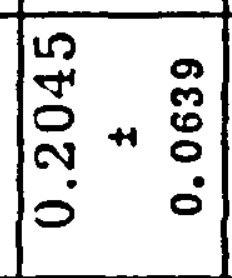 & 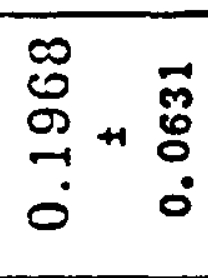 \\
\hline & & 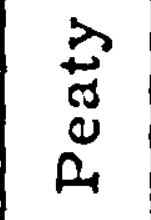 & mె & $\stackrel{m}{m}$ & 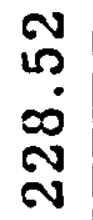 & 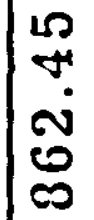 & \begin{tabular}{l}
$m$ \\
\hdashline \\
0 \\
10 \\
0
\end{tabular} & 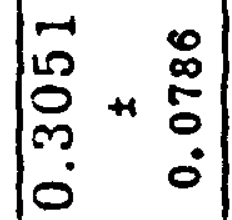 & 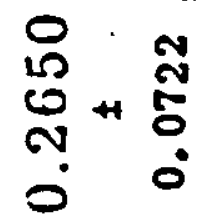 \\
\hline & & $\begin{array}{l}\overrightarrow{0} \\
\grave{0} \\
\frac{0}{U}\end{array}$ & $\begin{array}{l}\text { Ŵ } \\
\text { Nิ } \\
\text { - }\end{array}$ & $\begin{array}{l}\vec{D} \\
\stackrel{N}{N}\end{array}$ & $\begin{array}{l}m \\
\infty \\
\dot{-1} \\
0 \\
m \\
\dddot{m}\end{array}$ & 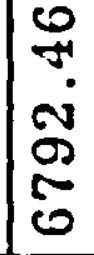 & $\mid \begin{array}{l}10 \\
0 \\
10 \\
0 \\
0 \\
10\end{array}$ & 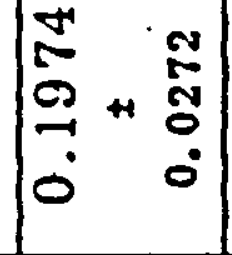 & 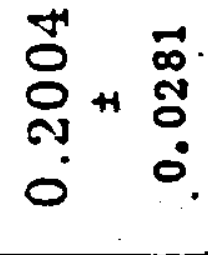 \\
\hline $\begin{array}{l}1 \\
0 \\
0 \\
0 \\
\vdots \\
0 \\
0 \\
0\end{array}$ & & $=\frac{n}{2}$ & 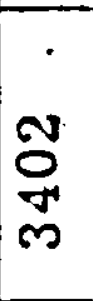 & $\underset{\text { mi }}{-1}$ & 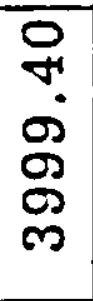 & $\begin{array}{l}+ \\
-1 \\
0 \\
N \\
1 \\
0 \\
0-1\end{array}$ & \begin{tabular}{l}
$m$ \\
0 \\
0 \\
0 \\
0 \\
\multirow{1}{1}{} \\
-1
\end{tabular} & $\left|\begin{array}{cc}0 & \\
\sim & 0 \\
N & 0 \\
N & 0 \\
0 & 0\end{array}\right|$ & 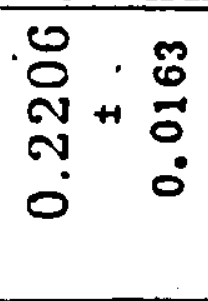 \\
\hline 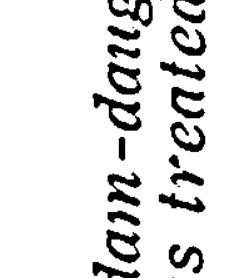 & 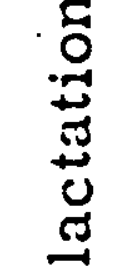 & $\begin{array}{l}\overrightarrow{3} \\
\text { స్ } \\
\text { స్ }\end{array}$ & $\underset{\sim}{\stackrel{N}{N}}$ & $\underset{m}{\tilde{m}}$ & $\begin{array}{l}ت \\
+ \\
\dot{H} \\
\text { m }\end{array}$ & $\begin{array}{l}\ddot{n} \\
\dot{0} \\
0 \\
\end{array}$ & $\begin{array}{l}0 \\
0 \\
0 \\
0 \\
0 \\
0 \\
0 \\
-1 \\
\end{array}$ & 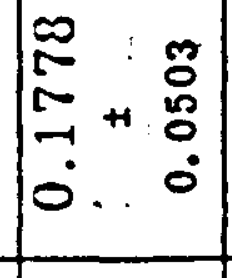 & \begin{tabular}{l}
0 \\
$\stackrel{0}{0}$ \\
$\infty$ \\
\hdashline+1 \\
0 \\
0 \\
0
\end{tabular} \\
\hline $\begin{array}{l}0 \\
\overline{0} .\end{array}$ & 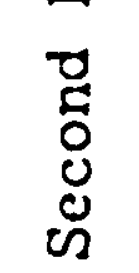 & 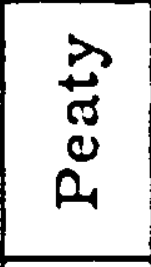 & $\stackrel{L}{\stackrel{H}{N}}$ & $\underset{\sim}{\stackrel{H}{*}}$ & 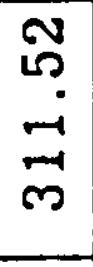 & 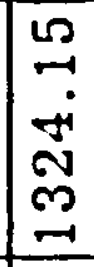 & $\begin{array}{l}9 \\
0 \\
10 \\
10 \\
1 \\
1\end{array}$ & 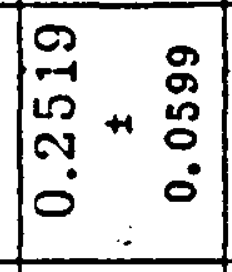 & 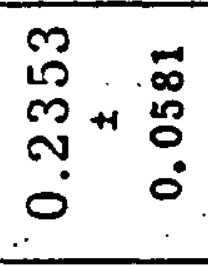 \\
\hline 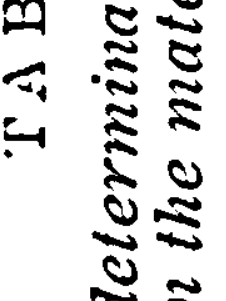 & & $\begin{array}{l}\overrightarrow{0} \\
\grave{0} \\
\vec{U}\end{array}$ & $\begin{array}{l}\text { N } \\
\text { D్ } \\
\text { N }\end{array}$ & 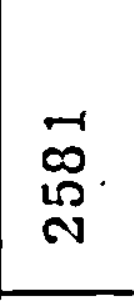 & $\begin{array}{l}\infty \\
\infty \\
\infty \\
\infty \\
\infty \\
\infty \\
\sim\end{array}$ & 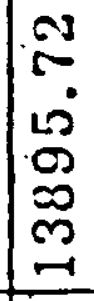 & 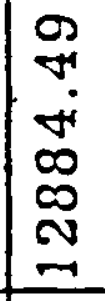 & 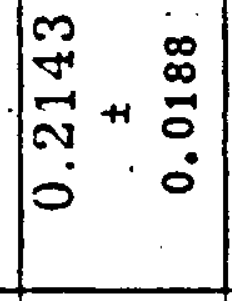 & 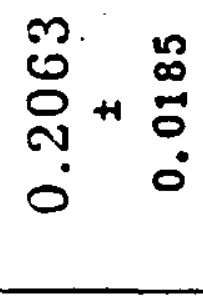 \\
\hline 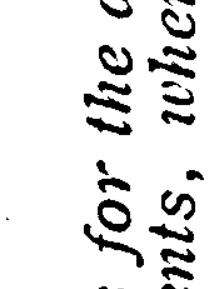 & . & 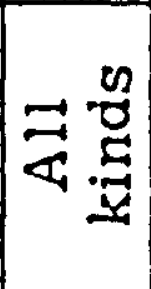 & $\begin{array}{l}\stackrel{10}{-1} \\
\underset{n}{+}\end{array}$ & $\underset{\not \rightarrow}{\not}$ & 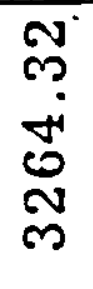 & 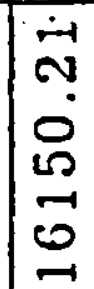 & 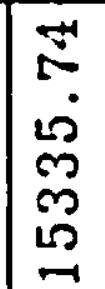 & 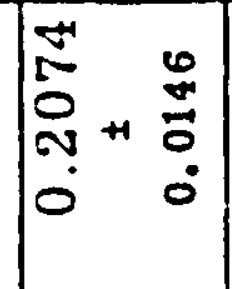 & 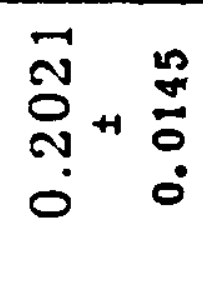 \\
\hline 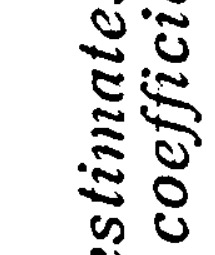 & $\stackrel{5}{.5}$ & $\begin{array}{l}\overrightarrow{3} \\
\stackrel{\vec{\pi}}{\pi} \\
\tilde{n}\end{array}$ & $\underset{\sim}{\mathscr{H}}$ & $\vec{F}$ & $\begin{array}{l}\stackrel{0}{o ̛ ~} \\
\stackrel{m}{m} \\
\ddot{m}\end{array}$ & $\begin{array}{l}0 \\
5 \\
0 \\
0 \\
5 \\
10\end{array}$ & $\mid \begin{array}{l}0 \\
\infty \\
\infty \\
0 \\
0 \\
10 \\
-1\end{array}$ & 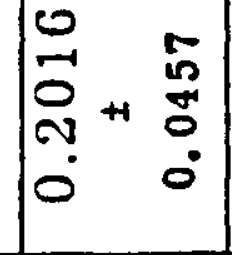 & 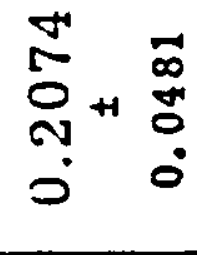 \\
\hline 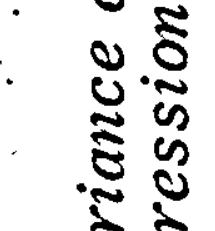 & 范 & 祭 & o & 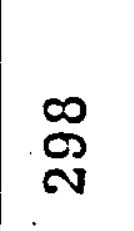 & 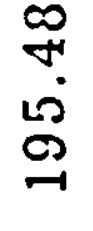 & $\begin{array}{l}m \\
v \\
0 \\
\infty \\
0\end{array}$ & $\begin{array}{l}\tilde{m} \\
\tilde{n} \\
\dot{0} \\
0 \\
0\end{array}$ & 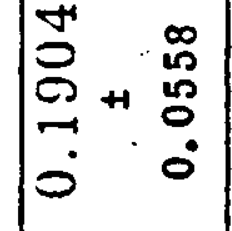 & $\begin{array}{l}0 \\
\stackrel{0}{0} \\
0 \\
\stackrel{9}{0} \\
\dot{0} \\
0 \\
0\end{array}$ \\
\hline 8 & & . & 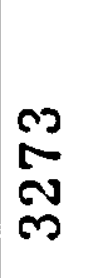 & 怠 & 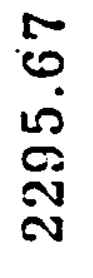 & $\begin{array}{l}5 \\
m \\
10 \\
\tilde{n} \\
\tilde{N} \\
\end{array}$ & 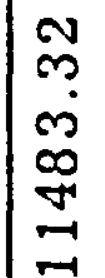 & 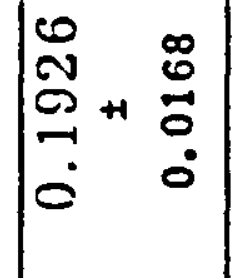 & $\begin{array}{ll}10 \\
10 \\
\infty \\
? \\
0 \\
0\end{array}$ \\
\hline$\underset{\widetilde{E}}{\widetilde{\Xi}}$ & 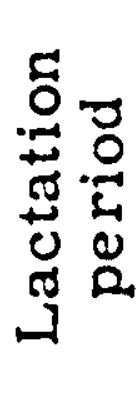 & 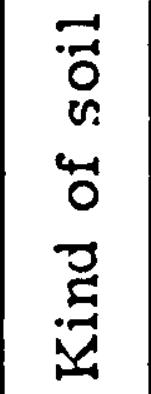 & $\begin{array}{l}02 \\
0 \\
0 \\
15 \\
15 \\
4 \\
0 \\
\dot{z} \\
\dot{z}\end{array}$ & 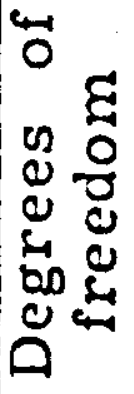 & $\frac{\widehat{3}}{\omega}$ & $\frac{\pi}{\mathscr{N}}$ & $\stackrel{\partial}{\omega}$ & 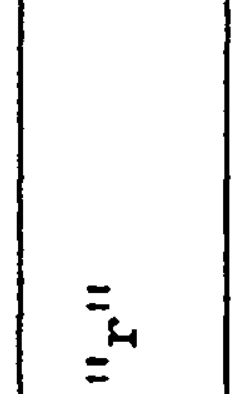 & $=0$ \\
\hline
\end{tabular}


The average heritability of milk yield as calculated by doubling the regression of daughter's records on dam's records, was $35.50 \%$ (see table 3 ). When it was calculated on the same base for each of the three lactation periods alone, it was $33.62 \%$ for the first period, $36.56 \%$ for the second, and $38.14 \%$, for the third lactation period. Again, doubling the regression coefficients, the heritability estimates of milk yield in each kind of soil were: $34.74 \%$ for the clayey soil groups, $38.88 \%$ for peaty, and $38.48 \%$ for the groups coming from the sandy soil.

When the differences caused by the effect of different soils on the production records were neglected, the heritability reached at was $36.58 \%$.

By doubling the dam-daughter correlation, the heritability estimates obtained were: $37.36 \%, 35.34 \%, 38.64 \%, 39.84 \%, 36.80 \%$; $41.84 \%$, and $38.22 \%$, in the same respect. The later values were on the average higher than those obtained by doubling daughter on dam regression coefficients. The differences were on the average highly significant.

Table No. 3 shows the above mentioned heritability estimates as calculated from doubling the dam-daughter comparisons within sires, and within kind of soil, as well as within the whole province.

The way that was used to get the average heritability fractions, was to multiply each regression, or correlation coefficient within groups, by the corresponding number of comparisons. Then by the addition of the totals and dividing this sum by the total number of comparisons, the average coefficients were gained. Doubling. such coefficients, gave the average herițability estimates mentioned in this investigation.

When the material was studied as a homogeneous population, rather than on an intra-sire basis, the average heritability estimate of milk yield, reached at by doubling the regression coefficient of daughter's on dam's records, was $39.60 \%$. When it was calculated for each of the three lactation periods under study, the estimates yielded the following heritabilities: $37.76 \%$ for the first period, $41.18 \%$ for the second, and $41.04 \%$ for the third lactation period. The heritability value of the same character in each kind of soil was: $39.12 \%$ for the groups reared on clayey soil, $44.90 \%$ for the peaty, and $39.34 \%$ for the groups that were producing on the sandy soil. When neglecting the effect of different soils, the average " $\mathrm{h} 2$ " of milk yield was $41.66 \%$.

When the dam-daughter correlation method was used, the average heritabilities were, $40.60 \%, 38.68 \%, 42.58 \%, 41.46 \%, 40.26 \%$, $47.04 \%, 38.74 \%$, and $42.70 \%$, in the same respect as was mentioned above.

The estimates shown in table No. 4 were on the average higher than the corresponding values of heritability given in table No. 3 . The statistical tests on the differences between the regression coefficients in table No. 1 and the corresponding values in table No. 2, proved that the differences were highly significant.

The heritability estimates obtained through the intra-sire groups as divided according to the kind of soil the animals were reared on, are more reliable than the other trials used in the present 


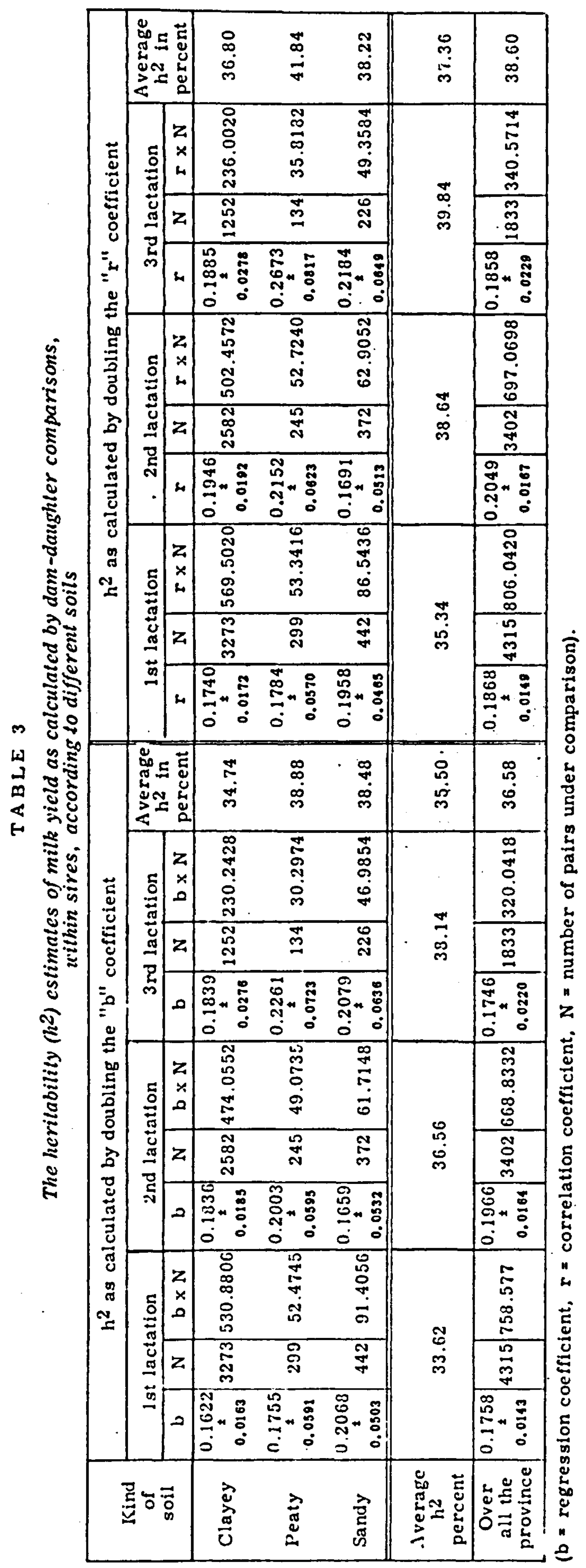




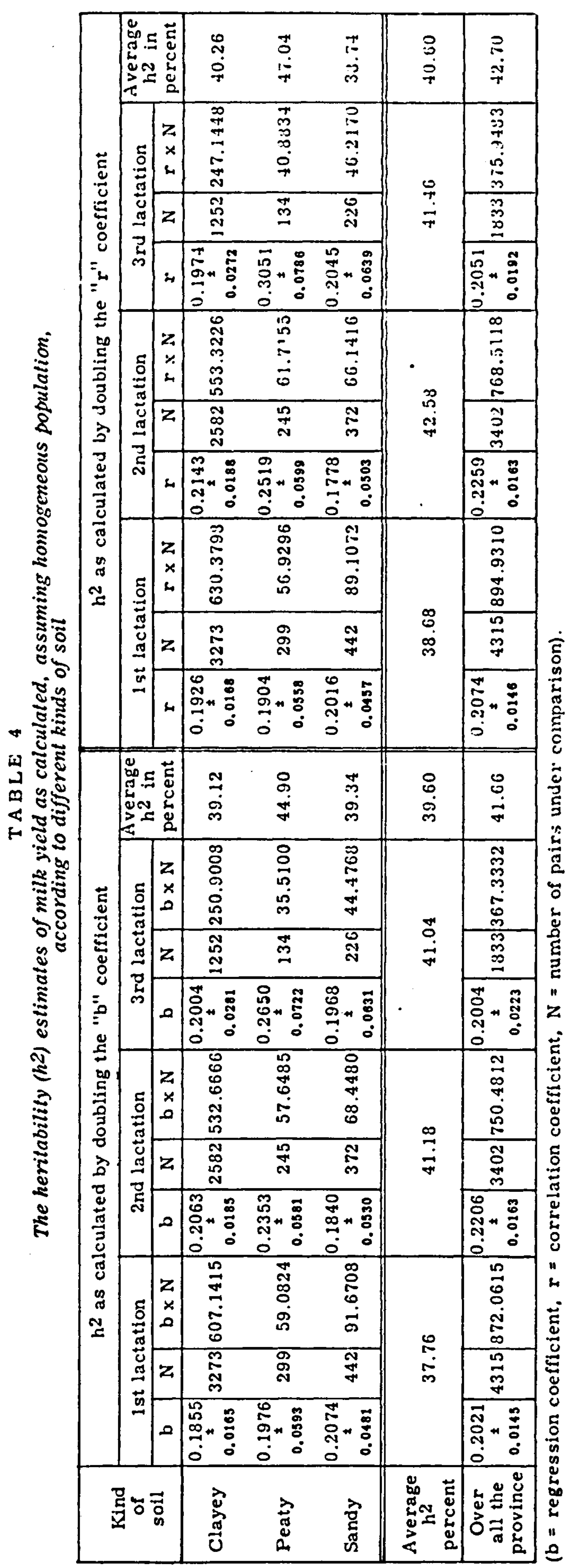


investigation to compute the heritable part of variance in milk yield as well as in fat percentage. The division into groups according to the kind of soil, excluded a great part of environmental nutritional variations between the three kinds of soil, which contributed a higher portion to the estimates, when the heritability was computed without differentiation between the three kinds of soil.

\section{B. Fat percentage}

The heritability of fat percentage was estimated applying the methods of daughter-dam comparisons within 117 bulls. The following results were obtained, using the same 9550 daughter-dam comparisons that were included in the study of the heritability of milk yield.

Table No. 5 shows the results of the analysis of variance and covariance, for the determination of daughter on dam regression, and dam-daughter correlation coefficients.

It is shown in table 5 that the dam-daughter correlation method yielded the following coefficients: First fat tests, for groups reared on clayey soil $0.4487 \pm 0.0142$, for those kept on peaty soil $0.4236 \pm 0.0483$, for the sandy soil groups $0.3439 \pm 0.0427$, and when no soil differentiation was made, the average correlation coefficient was $0.4295 \pm 0.0126$. The respective regression coefficients were: $0.4111 \pm 0.0145,0.4047 \pm 0.0511 ; 0.3728 \pm 0.0492$, and $0.4022 \pm 0.0130$.

For the second fat tests, and in the same order as mentioned above, the average correlation coefficients were: $0.3794 \pm 0.0171$, $0.3371 \pm 0.0579,0.3694 \pm 0.0456$, and $0.3792 \pm 0.0149$; where as the average regression coefficients were: $0.3559 \pm 0.0173,0.3214$ $\pm 0.0588,0.3640 \pm 0.0485$, and $0.3570 \pm 0.0152$, in the same respect. In the case of the third fat tests, the respective values were; $0.4127 \pm 0.0239,0.3845 \pm 0.0750,0.3773 \pm 0.0585$, and 0.4111 \pm 0.0198 for the correlation coefficients; and $0.3919 \pm 0.0245$, $0.3025 \pm 0.0644,0.3598 \pm 0.0593$, and $0.3812 \pm 0.0201$ for the regression coefficients, in the same respect.

As from the whole material no sire group with less than fifteen pairs was allowed in the comparisons, the total number of comparisons in the case of neglecting the effect of soil, was always higher than the total number of dam-daughter pairs that can be reached at by the addition of the number of comparisons in the groups reared on different kinds of soil. This was for the same reason that was mentioned in the results of "milk yield".

In another attempt, when assuming homogeneous population, rather than on an intra-sire basis, the variance and covariance estimates are shown in table No. 6 .

The average heritability of fat percentage, as calculated by doubling the regression of daughter's records on dam's records, was $76.52 \%$ (see table 7 ). On the same basis, the average estimates of heritability for each of the three tests coming from the first three lactation periods were: the first period $81.28 \%$, the second period $70.82 \%$, and the third period $75.98 \%$. 


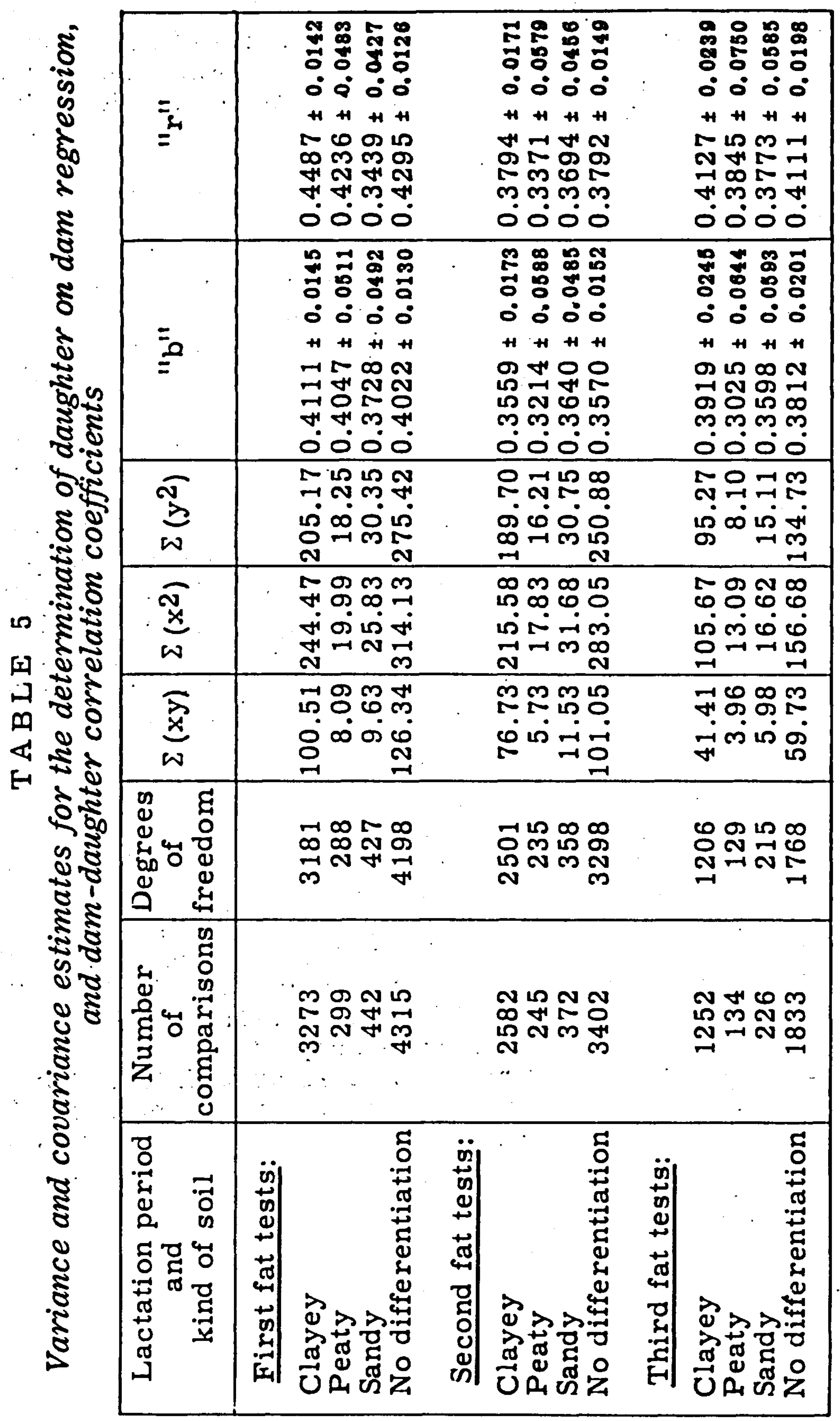




\begin{tabular}{|c|c|c|c|c|c|c|c|c|c|}
\hline \multirow{13}{*}{ 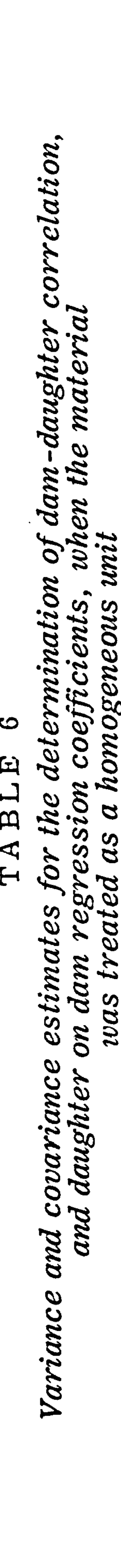 } & \multirow{4}{*}{ 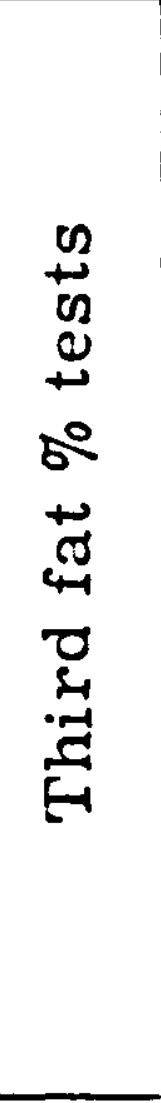 } & 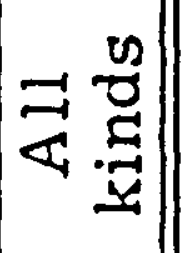 & $\begin{array}{l}n \\
\infty \\
\infty \\
-1\end{array}$ & $\begin{array}{l}\text { N్} \\
\infty \\
\infty \\
-1\end{array}$ & $\begin{array}{c}0 \\
\sim \\
0 \\
\end{array}$ & $\begin{array}{l}n \\
1 \\
\infty \\
5 \\
-1\end{array}$ & $\mid \begin{array}{c}N \\
\sim \\
\infty \\
\infty \\
-1\end{array}$ & 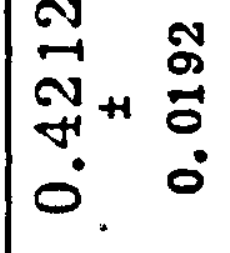 & 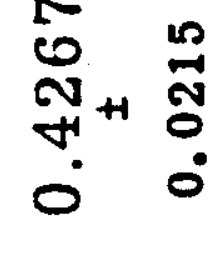 \\
\hline & & D্d & $\mid \begin{array}{c}0 \\
N \\
\mathcal{N}\end{array}$ & $\stackrel{\text { ก }}{\text { ஸै }}$ & $\begin{array}{l}m \\
\stackrel{n}{0} \\
0\end{array}$ & $\begin{array}{l}\vec{n} \\
\ddot{\sigma} \\
\ddot{-1}\end{array}$ & $\mid \begin{array}{l}0 \\
0 \\
\tilde{\sigma} \\
-1\end{array}$ & $\mid \begin{array}{ll}N & 0 \\
0 & 0 \\
0 \\
m \\
m & 0 \\
0 & 0 \\
0 & 0\end{array}$ & 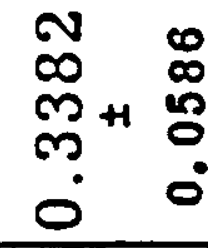 \\
\hline & & 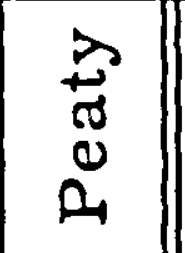 & $\begin{array}{l}+ \\
m \\
-1\end{array}$ & $\stackrel{m}{m}$ & $\begin{array}{l}\vec{n} \\
\dot{+}\end{array}$ & 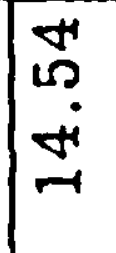 & 落 & 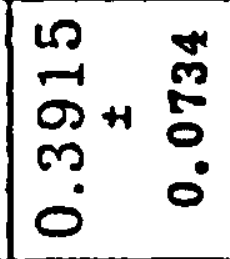 & $\begin{array}{ll}\stackrel{+}{0} & \infty \\
0 & 0 \\
0 & + \\
ஸ & 0 \\
0 & 0\end{array}$ \\
\hline & & 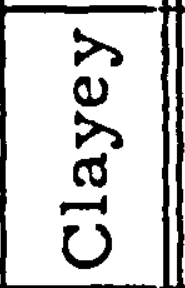 & $\begin{array}{l}\tilde{N} \\
\mathfrak{N} \\
\mathfrak{-}\end{array}$ & 공 & \begin{tabular}{l|} 
\\
$\infty$ \\
0 \\
0 \\
0
\end{tabular} & $\begin{array}{l}10 \\
0 \\
\infty \\
-1 \\
-1\end{array}$ & $\begin{array}{l}\tilde{m} \\
\ddot{+} \\
\dot{0} \\
n \\
n\end{array}$ & 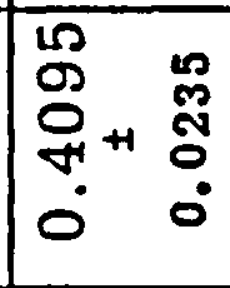 & $\begin{array}{ll}0 & 0 \\
0 & \stackrel{0}{0} \\
m_{H}+ & 0 \\
0 & 0\end{array}$ \\
\hline & $\stackrel{n}{0}$ & 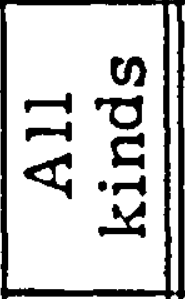 & 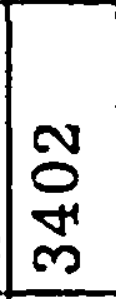 & $\vec{O}$ & $\begin{array}{l}0 \\
\infty \\
\infty \\
m \\
-1\end{array}$ & $\begin{array}{l}+ \\
\infty \\
0 \\
m \\
m\end{array}$ & $\begin{array}{l}10 \\
m \\
10 \\
1 \\
m\end{array}$ & $\mid \begin{array}{ll}m & m \\
\sigma & 2 \\
0 & +1 \\
\dot{0} & 0 \\
0 & 0\end{array}$ & $\begin{array}{ll}\vec{N} & \infty \\
\exists & \stackrel{0}{0} \\
\ddot{0} & 0 \\
0 & 0\end{array}$ \\
\hline & $\begin{array}{l}\stackrel{0}{+} \\
\stackrel{0}{0} \\
\stackrel{0}{0}\end{array}$ & 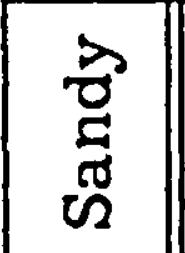 & $\underset{\sim}{\stackrel{N}{N}}$ & $\underset{n}{\tilde{m}}$ & $\begin{array}{l}+1 \\
0 \\
\dot{\theta}\end{array}$ & $\mid \begin{array}{l}0 \\
\infty \\
0 \\
0 \\
m\end{array}$ & $\begin{array}{l}\vec{m} \\
\dot{m}\end{array}$ & 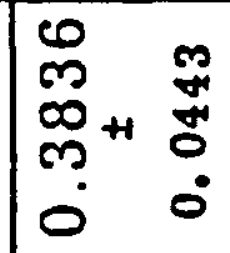 & $\begin{array}{ll}0 & 0 \\
0 & 0 \\
0 & 0 \\
0 & 0\end{array}$ \\
\hline & $\begin{array}{l}\text { 己 } \\
0 \\
0 \\
\mathscr{~}\end{array}$ & $\begin{array}{l}\stackrel{\vec{\omega}}{\sigma} \\
0 \\
0 \\
0\end{array}$ & $\mid \begin{array}{l}0 \\
\stackrel{N}{1} \\
N\end{array}$ & $\stackrel{\mathbb{H}}{\stackrel{\sim}{*}}$ & $\begin{array}{l}\infty \\
0 \\
0 \\
0\end{array}$ & ठิ & 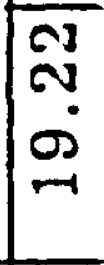 & $\mid \begin{array}{ll}\begin{array}{l}4 \\
0 \\
0 \\
10\end{array} & 5 \\
n & 0 \\
0 & 0 \\
0 & 0\end{array}$ & 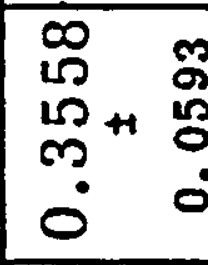 \\
\hline & & $\overrightarrow{0}$ & $\begin{array}{l}N \\
\infty \\
N \\
N \\
N \\
\end{array}$ & 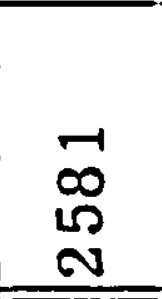 & $\begin{array}{l}0 \\
\infty \\
0 \\
0 \\
0 \\
-1\end{array}$ & $\begin{array}{l}m \\
0 \\
m \\
m \\
\omega \\
\omega\end{array}$ & 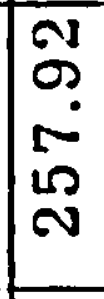 & 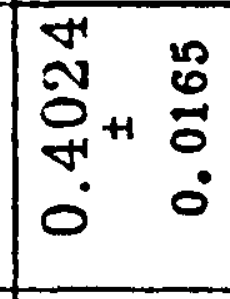 & 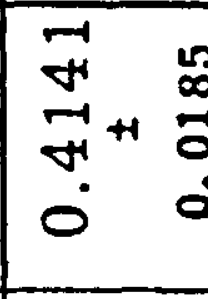 \\
\hline & & 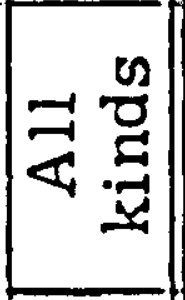 & $\begin{array}{l}10 \\
-1 \\
m \\
7\end{array}$ & $\stackrel{+}{\not}$ & $\begin{array}{c}m \\
0 \\
-1 \\
0 \\
-1\end{array}$ & $\begin{array}{l}\infty \\
\infty \\
\infty \\
\text { in } \\
m\end{array}$ & $\begin{array}{l}0 \\
m \\
\dot{f} \\
0 \\
m\end{array}$ & $\mid \begin{array}{cc}10 & 5 \\
\infty & 9 \\
4 & 0 \\
4 & 0 \\
0 & 0 \\
0 & 0\end{array}$ & 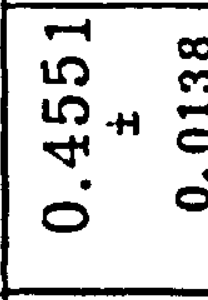 \\
\hline & 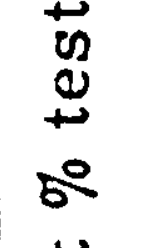 & 总 & 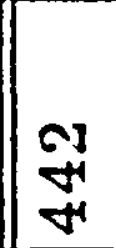 & $\stackrel{H}{H}$ & $\begin{array}{l}\tilde{g} \\
\mathfrak{v} \\
\stackrel{\sim}{*}\end{array}$ & O & $\mid \begin{array}{l}\infty \\
0 \\
10 \\
0\end{array}$ & 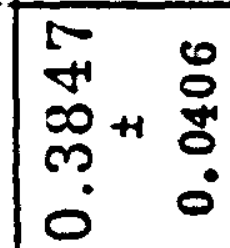 & 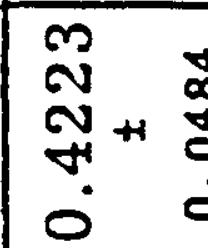 \\
\hline & 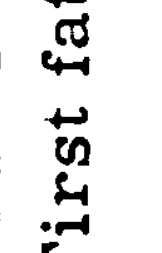 & \begin{tabular}{l}
7 \\
\multirow{\pi}{\pi}{} \\
0 \\
0
\end{tabular} & 吕 & $\begin{array}{l}\infty \\
\text { o } \\
\text { బ. }\end{array}$ & $\begin{array}{l}\infty \\
m \\
\dot{\sigma}\end{array}$ & 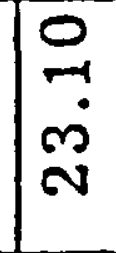 & \begin{tabular}{l}
10 \\
\hdashline \\
0 \\
0
\end{tabular} & 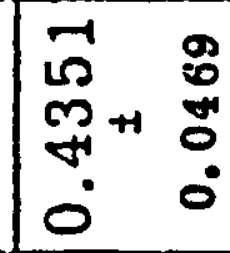 & 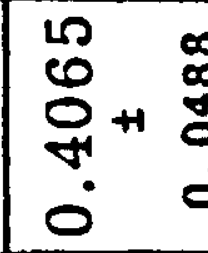 \\
\hline & 14 & $\stackrel{\overrightarrow{0}}{\stackrel{0}{0}}$ & $\begin{array}{l}m \\
5 \\
N \\
m \\
m\end{array}$ & 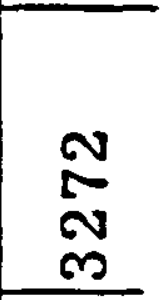 & $\begin{array}{l}\vec{F} \\
\dot{F} \\
\stackrel{-}{N}\end{array}$ & $\begin{array}{l}0 \\
0 \\
0 \\
0 \\
0\end{array}$ & 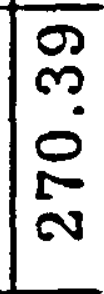 & 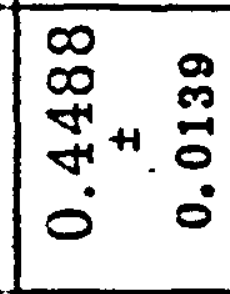 & \begin{tabular}{ll}
5 & $c$ \\
$\infty$ & 0 \\
\multirow{H}{*}{+1} & 0 \\
0 & 0 \\
0 & $c$
\end{tabular} \\
\hline & 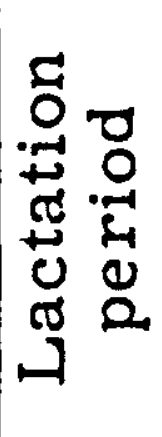 & 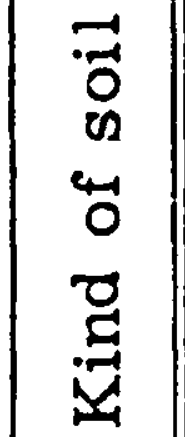 & 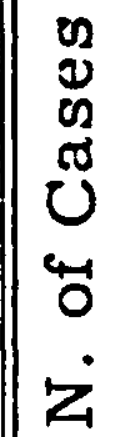 & 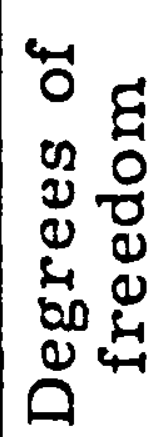 & $\frac{x}{\omega}$ & $\frac{\widetilde{x}}{\omega}$ & $\frac{\widetilde{\partial}}{\partial}$ & $=$ & مِ \\
\hline
\end{tabular}


When the estimates were made according to groups reared on different kinds of soil, the average heritabilities were: clayey soil $77.52 \%$, peaty soil $70.88 \%$, and sandy soil $73.36 \%$. When the differences coming from different kinds of soils were neglected, and the whole material was pooled, the heritability of fat percentage averaged as $76.40 \%$.

By doubling the dam-daughter correlations, the heritability estimates were: $81.58 \%, 87.04 \%, 74.98 \%, 81.06 \%, 83.42 \%, 76.92 \%$, $72.04 \%$, and $81.60 \%$, in the same respect.

Table No. 7 shows the above mentioned estimates of heritability as computed from the two methods of daughter-dam comparisons.

Assuming homogeneous population, rather on an intra-sire basis, the average heritability estimates were as shown in table No. 8.' The differences between the regression values obtained in table 8 , and those shown in table 7 , were on the average highly significant.

From the assumption of the population homogeneity, the average heritability of fat percentage, as being based on the daughterdam regression method, was $84.44 \%$ (see table 8 ). On the same basis, and in accord to each of the three production periods, the average heritability of fat percentage was: First period $88.52 \%$; second period $80.90 \%$; and third period $81.28 \%$. By doubling the average regression coefficients that came from groups within each kind of soil, the estimates of heritability were: $86.58 \%$ for clayey groups; $73.28 \%$ for peaty groups; and $77.06 \%$ for sandy groups. When no differentiation between the different soils was made, the average heritability was $86.88 \%$.

Estimates based on dam-daughter correlation method yielded the following heritabilities: $83.52 \%, 88.14 \%, 79.38 \%, 80.20 \%$, $85.00 \%, 79.82 \%, 75.78 \%$, and $86.00 \%$, in the same order as mentioned in the above method.

The heritability of fat percentage in all cases in this investigation, was about two times the heritability of milk yield. 


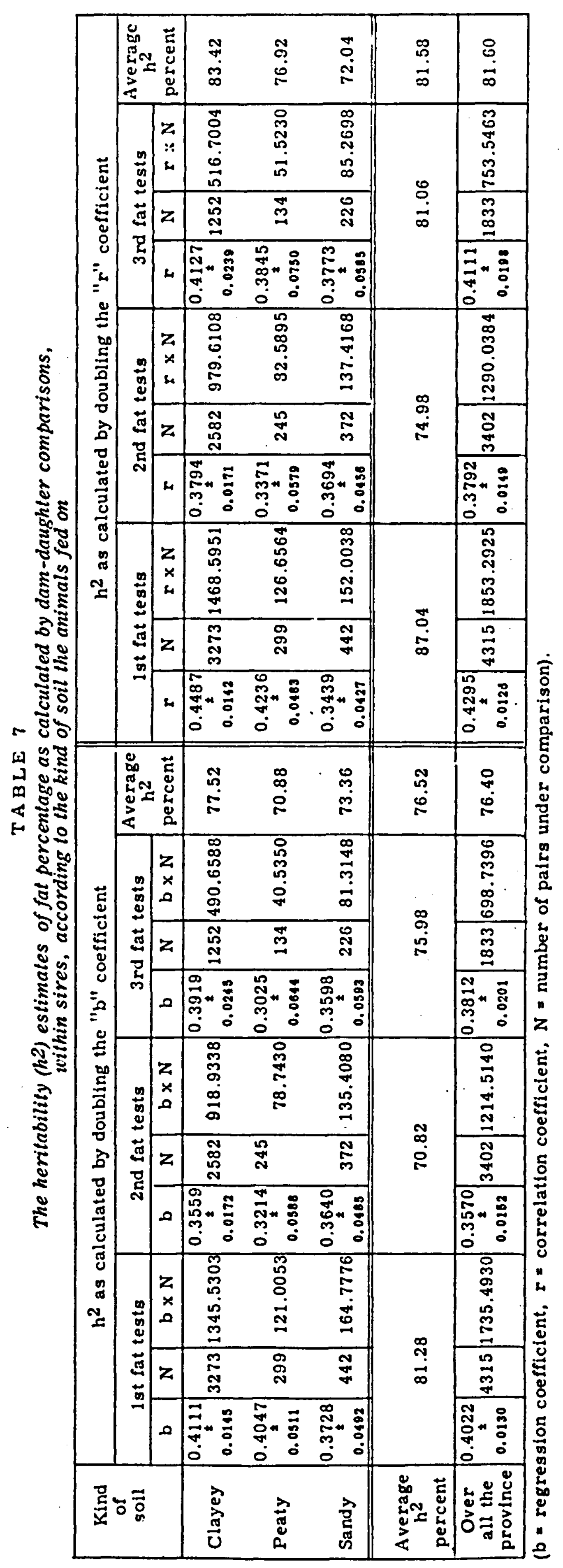




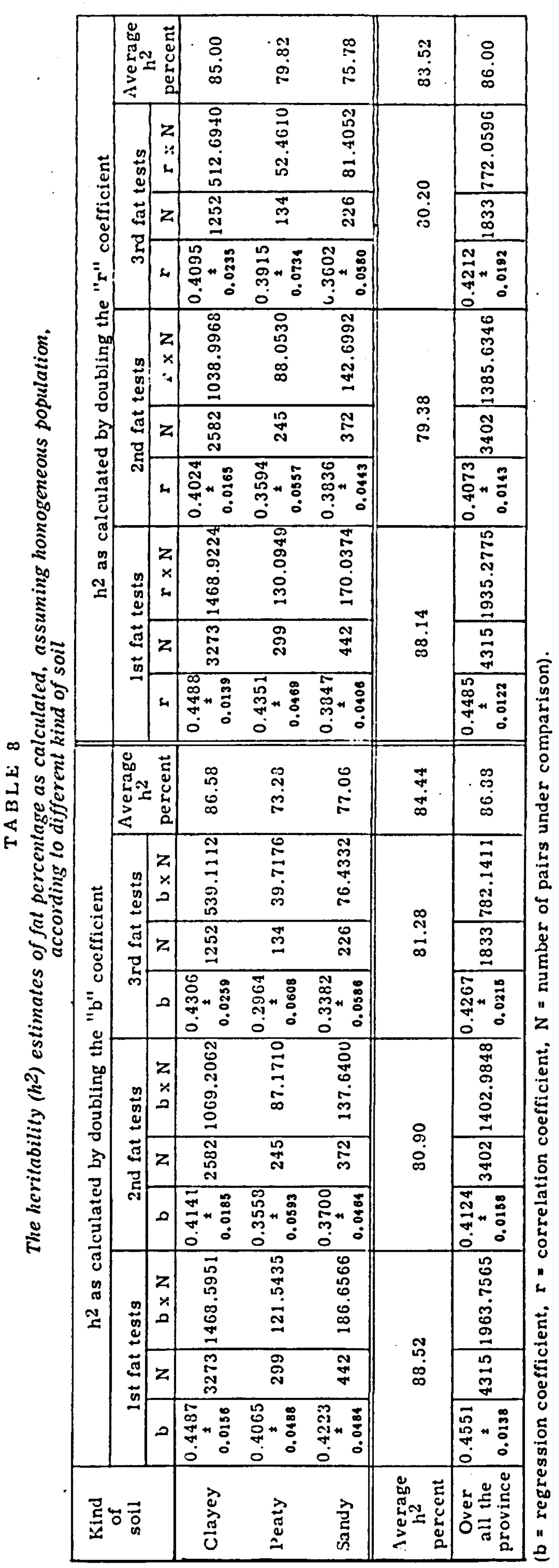




\section{Chapter VI}

\section{GENERAL DISCUSSION}

Heredity and environment are the two main factors that affect the phenotypic expression of the characters of animals. To bring out more clearly the part played by heredity in milk yield and fat percentage, it is necessary to try to eliminate the contribution caused by environmental factors in measuring " $h 2$ " by the damdaughter correlation method. To reach this point of accuracy, there are two means: i.e. 1. using correction factors for each environmental component in attempt to standardise the records for major non-hereditary sources; 2 . or, to find all the animals under the same environmental conditions. The latter method is more in accordance to reality, since the determination of the effect of environmental factors is usually difficult, and consequently the derived correction factors applied in correcting individual expressions cannot be accurate. Bakhoven (1948) advised that apart from age and lactation period, one should not use correction factors. He added that it must not be forgotten that no accurate corrections could be made for feeding, individual health circumstances, and managements.

On the other hand, in practice, we cannot find all the animals needed for an investigation, under strictly the same conditions. Naturally in estimating the heritability of economic characteristics in animal breeding, we do not usually put the animals chosen for the research, under well designed laboratory conditions, in order to eleminate completely the effect of environmental contribution to our estimates. Even if we do so, we still cannot exclude the part played by the interaction between the different genotypes of the animals, and the standard environment of the experiment.

One should then expect such estimates of heritability to contain a part of the non-heritable portion of the variance.

The following discussion is to make clear the degree to which the results of the present research, were affected by the most important components of environment.

1. Age of cow at calving: According to the known fact, cows tend to produce more with advancing age, and succeeding lactations, till a certain lactation period. Bosma (1935), working with the Friesian Herdbook cattle in Friesland, and after standardizing the milk records for different non-heritable factors, found that the cow, on the average, attained her highest milk record at the age of 8 years. De Bas (1936) concluded from his study of the cattle at 10 stables in the district of "RoosendaalHolland", that the Friesian cow attained her highest production at 
the seventh lactation period; i.e. around 9 years old. Gowen (1924) analysed a large number of 365 days records for HolsteinFriesian cows, and found that milk yield rises at an even decreasing rate, as the age of the cow increased, to the age of eight years. From this age of maximum production, their milk yields declined at an even increasing rate as the age increased. Johans son and Hansson (1940) reported that milk yield of cows is influenced by their age at calving. Horn (1950) found that the correlation between average annual milk production and length of life in Hungarian Red Spotted cows, was $0.15 \pm 0.026$. Ragab et al (1953) showed that the milk yield of the Egyptian buffalo increased with advance in age, until the maximum production was attained at the third lactation (6.5 yrs.), after which it declined. Ragab et al (1954) found that milk yield of the Egyptian cow increased with a decreasing rate, with the advance of age, till the 5th to 6 th lactation. Bekedam (1954) from a study with controlled Red-\&-White cows (M.R.Y.breed), in the province of "Noord Brabant"-Holland, found that the cow attained her highest production at the age of 8.1 to 9.1 years.

In the studies involving age standardization, investigators either have used the published breed factors, which naturally apply mostly to the population being studied, or they have derived factors from the records of the material under discussion. Bosma (1935) from his study of the Herdbook Friesian cattle in Friesland, divided the milk production in different ages of the cow, in percentages, assuming that the production was $100 \%$ at the age of 8 years. His table derived from his study is: $\%$ of production years months $\%$ of production years months

$\begin{array}{rrrrrr}56 & 1 & 8 & 87 & 4 & 3 \\ 59 & 1 & 10 & 89 & 4 & 6 \\ 62 & 2 & - & 91 & 4 & 9 \\ 64 & 2 & 2 & 92 & 5 & - \\ 67 & 2 & 4 & 94 & 5 & 6 \\ 69 & 2 & 6 & 96 & 6 & - \\ 71 & 2 & 8 & 98 & 6 & 6 \\ 73 & 2 & 10 & 99 & 7 & - \\ 75 & 3 & - & 100 & 8 & - \\ 78 & 3 & 3 & 99 & 9 & - \\ 80 & 3 & 6 & 98 & 10 & - \\ 83 & 3 & 9 & 95 & 11 & - \\ 85 & 4 & - & 91 & 12 & -\end{array}$

Working in the same field, De Bas (1936) from his material at "Roosendaal-Holland", derived the following results:

$\mathrm{N}$. of calving $\%$ of production $\mathrm{N}$. of calving $\%$ of production

$\begin{array}{rrrr}1 \text { st } & 72 & 5 \text { th } & 97 \\ \text { 2nd } & 85 & 6 \text { th } & 98 \\ 3 \text { rd } & 91 & 7 \text { th } & 100 \\ 4 \text { th } & 94 & 8 \text { th } & 99\end{array}$


Many other studies of records which involved age standardization, as derived from the records studied, have been reported. Rietz (1909) applied age corrections to butterfat records. Eckle (1911) gave a tabulation saying that, "a dairy" cow on the average as a two years old may be expected to produce about $70 \%$, as a three years. old around $80 \%$, and as a four years old about $90 \%$ of the milk and butterfat she will produce under the isame treatment when mature". Turner, et al (1924) worked out convension factors for Jersey: Shorthorn, Ayrshire, Guernsey, and Holstein-Friesian breeds, in order to get comparative values for the cows of various ages. Lush, and Shrode (1950) used the "Eckles' = correction factors with 43000 Holstein-Friesian cows' records, and concluded that the method removed about $52 \%$ of the age variance.

From the results given by Bosma (1935) and De Bas (1936), we find that both differed in their results that were derived from Friesian cattle records in different places in the Netherlands. The correction factor is: more suitable for the population it was derived from.

In the present study, mostly in all cases, there was a difference that did not exceed 6 months between the age of the daughter, and the age of her dam, at the same number of calving. It was found reasonable enough that, because of that slight difference in age, which would not have affected the differences found between dam-daughter pairs average! daily records to a high degree, age correction factors were not used. One can also expect that this non-heredity factor, contributed only a little, "if any, to our estimates of heritability obtained in the present study.

2. Lenght of lactation period: Gaines (1927) said that "the amount of milk or butterfat produced during any lactation, is governed by three major physiolngical elements of lactations; the height and persistency: of the maximum yield, and the length of the lactation period". Gaines and Davidson (1926) measured the correlation between the length of record, and total yield as the

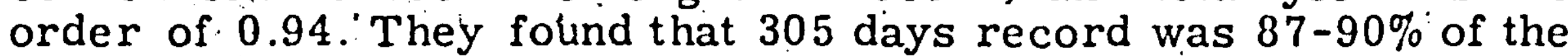
365 days record. Rice $(1942-$ p. 566) reported that, to convert 365 days record to a 305 days basis, multiply by 0.85 , and to convert. 305 days record to 365 -days basis, multiply by 1.17 . Bekedam (1954) from his study with the Red-\&-White (M.R.Y. Holland), cattle in the province of "Noord Brabant", concluded that from periods ranging between 250-490 days, the highest daily production was attained at the age"2.3-3.2 years when the lactation period was 251-266. For the age from 3.2 years up to 9.1 years, the highest records could be obtained from lactation periods ranging between 266 to 281 days.

Under the conditions of the present study, only normal lactations with duration of 260-360 days were allowed. Figures 8, 9, and 10 show clearly the great similarity between the dam-daughter pairs, with regard to the length of their lactation periods. As it is considered in such cases that the length of lactation period would have mildly affected the dam-daughter records, no correction factors were used, and the average milk yield per day was taken as a criterion in all the comparisons in this investigation, to measure the heritability of milk yield. 


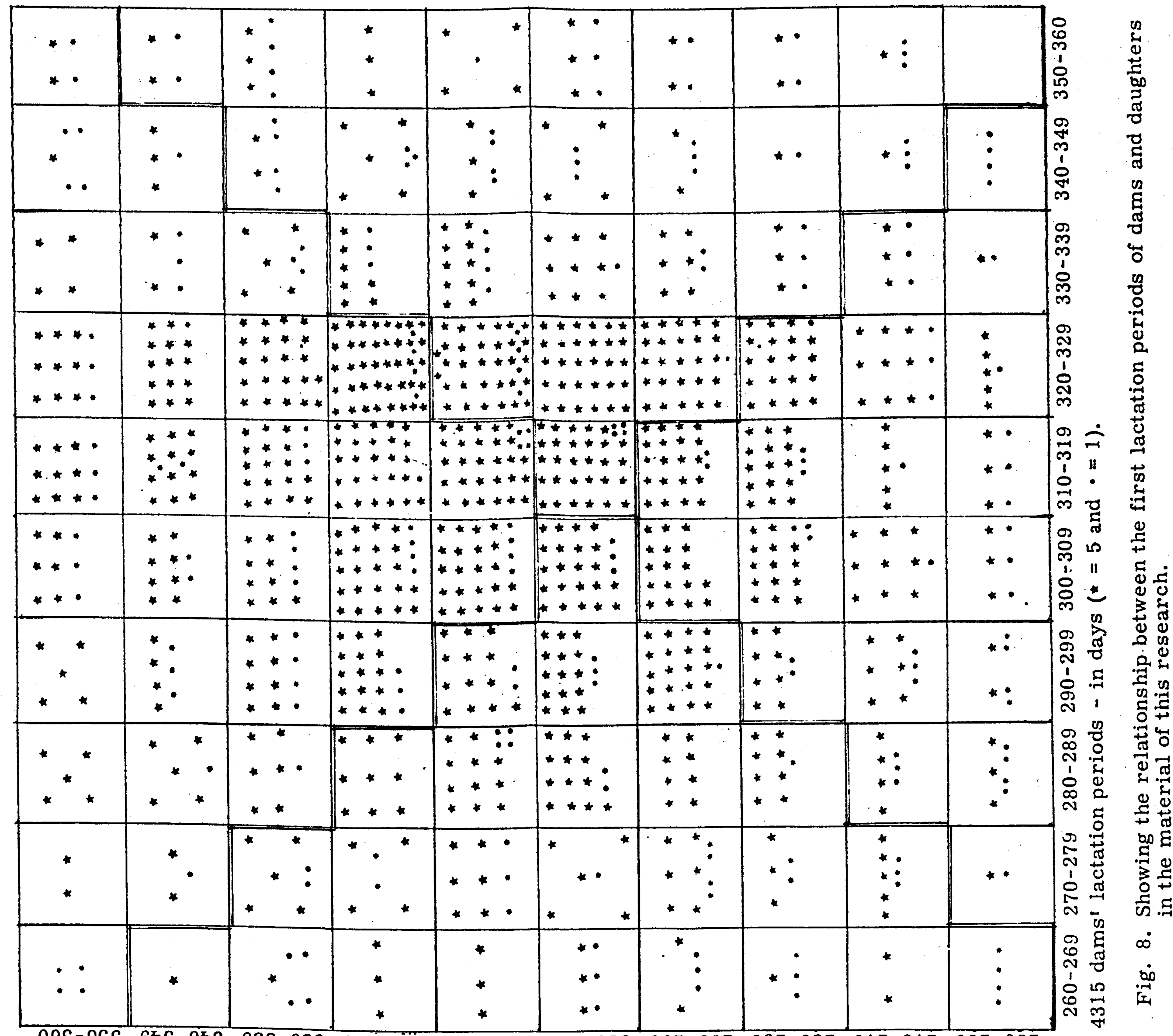

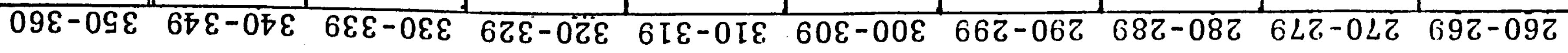

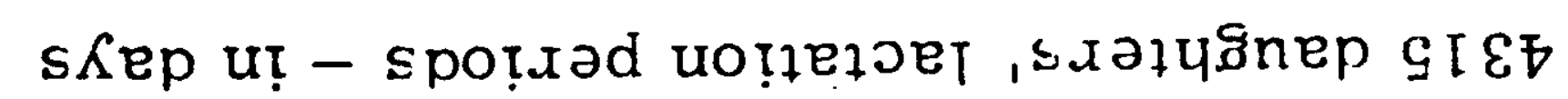




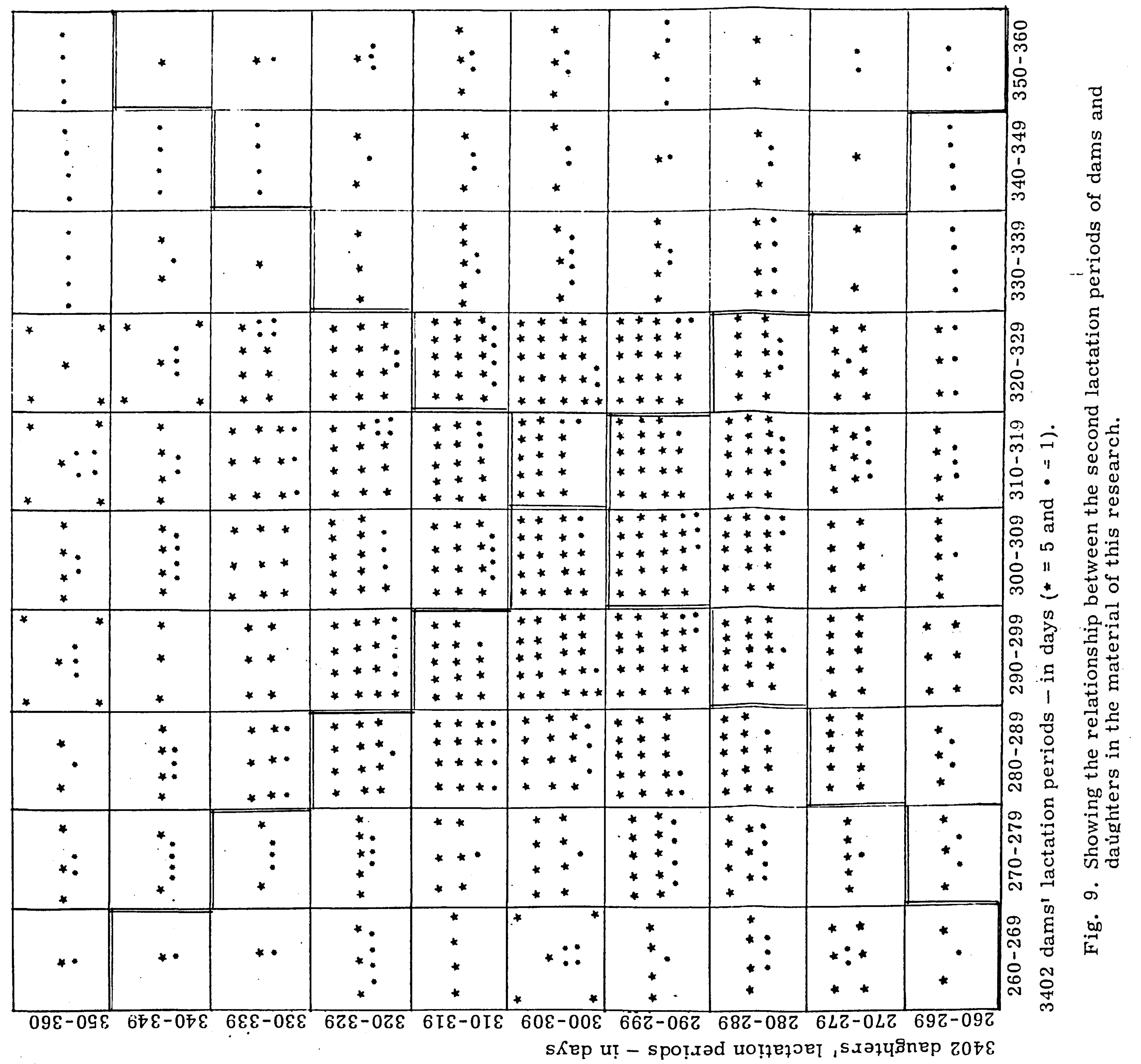




\begin{tabular}{|c|c|c|c|c|c|c|c|c|c|c|c|}
\hline • & : & $\dot{.}$ & $:$ & : & ** & • & $:$ & $*^{\circ}$ & • & $\mid \begin{array}{l}0 \\
0 \\
0 \\
1 \\
0 \\
0 \\
0 \\
m\end{array}$ & \\
\hline - & : & $\dot{:}$ & + & : & $\begin{array}{l}* \\
* \\
*\end{array}$ & $*^{*}$ & $*$ & : & & 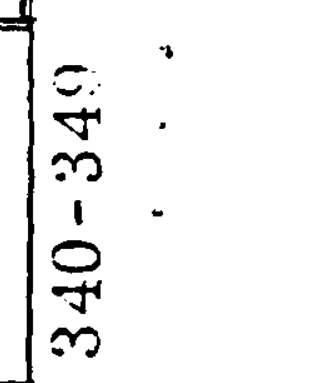 & 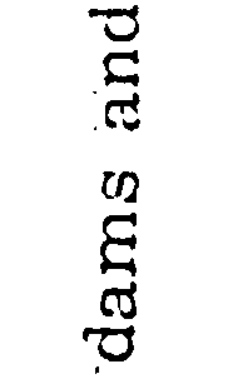 \\
\hline $\begin{array}{l}: \\
\dot{ } \\
\dot{ }\end{array}$ & * & *: & $\begin{array}{l}* \\
*\end{array}$ & * & $\begin{array}{l}* \\
* \\
*\end{array}$ & ${ }_{*}^{*}$ & * & * & $\therefore$ & $\begin{array}{l}0 \\
\infty \\
m \\
m \\
1 \\
0 \\
m \\
m\end{array}$. & 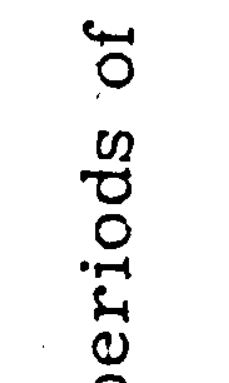 \\
\hline * & *: & $\begin{array}{l}* \\
* \\
* \\
* \\
\end{array}$ & $\begin{array}{lll}* & * \\
* & * \\
* & * \\
\end{array}$ & $\begin{array}{l}* \\
* \\
* \\
* \\
*\end{array}$ & $\begin{array}{l}* * \\
* * \\
* * \\
* *\end{array}$ & $\begin{array}{ll}* & 0 \\
* & * \\
* & * \\
* & * \\
* & * \\
\end{array}$ & $\begin{array}{l}* * \\
* * \\
* *\end{array}$ & $*$ & $\stackrel{*}{*}$ & $\begin{array}{l}\mathscr{\sigma} \\
\text { N } \\
m \\
1 \\
0 \\
\hat{N} \\
m\end{array}$ & 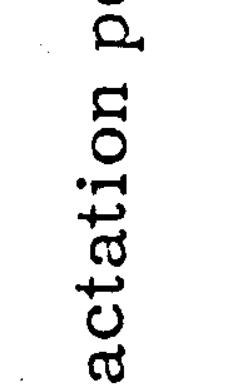 \\
\hline $\begin{array}{l}* \\
* \\
*\end{array}$ & $*$ & $\begin{array}{l}* \\
* \\
* \\
*\end{array}$ & $\begin{array}{ll}* & * \\
* & * \\
* & *\end{array}$ & $\begin{array}{l}* * \\
* \\
* \\
* \\
*\end{array}$ & $\begin{array}{l}* * \\
* * \\
* * \\
* \\
*\end{array}$ & $\begin{array}{l}* * * \\
* * * \\
* * * \\
* * * \\
* * *\end{array}$ & 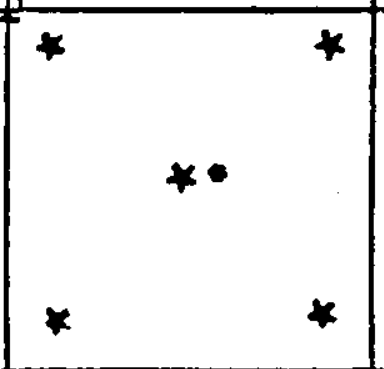 & $\begin{array}{l}* \\
* \\
* \\
*\end{array}$ & $\begin{array}{l}* \\
* \\
*\end{array}$ & 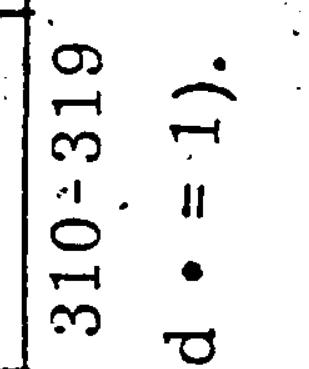 & 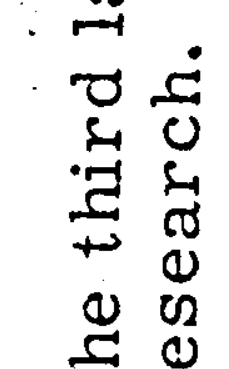 \\
\hline : & * & $\begin{array}{l}* \\
* \\
*\end{array}$ & $\begin{array}{l}* \\
* \\
* \\
* \\
*\end{array}$ & $\begin{array}{l}* * \\
* * \\
* * \\
*\end{array}$ & 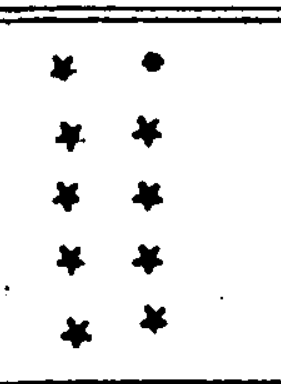 & $\begin{array}{l}* * \\
* * \\
* * \\
* * \\
\end{array}$ & $\begin{array}{ll}* & * \\
* & * \\
* & * \\
* & * \\
* & *\end{array}$ & * & $\begin{array}{l}* \\
* \\
*\end{array}$ & 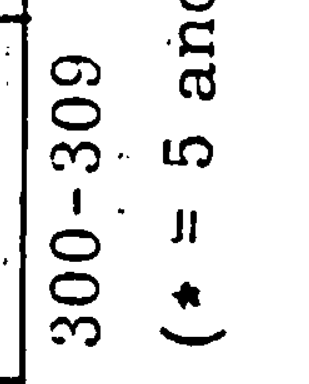 & 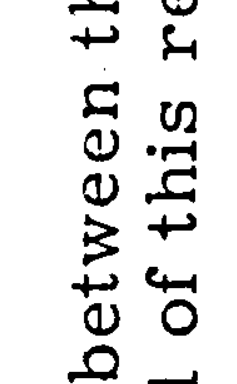 \\
\hline $\begin{array}{l}* \\
* \\
*\end{array}$ & $*$ & $\begin{array}{l}* \\
* \\
* \\
* \\
*\end{array}$ & $\begin{array}{|lll|}* & & * \\
& \because & \\
* & & * \\
\end{array}$ & $\begin{array}{l}+1 \\
* * \\
* * \\
* *\end{array}$ & $\begin{array}{ll}* & * \\
* & * \\
* & * \\
* & * \\
* & *\end{array}$ & $\begin{array}{l}* * \\
* * \\
* * \\
* \\
*\end{array}$ & $\begin{array}{lll}* & * \\
* & * \\
* & * \\
* & * \\
\end{array}$ & $\begin{array}{l}* * \\
* * \\
*\end{array}$ & *: & 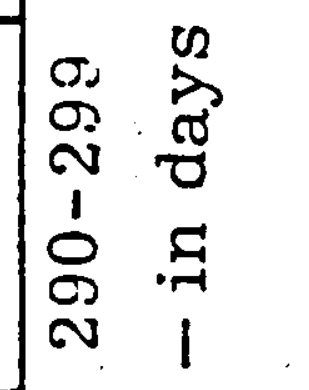 & 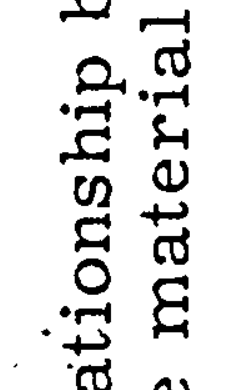 \\
\hline$:$ & $\begin{array}{l}* \\
* \\
*\end{array}$ & $\begin{array}{l}* \\
* \\
*\end{array}$ & $\begin{array}{l}* \\
\because \\
*\end{array}$ & $\begin{array}{l}* \\
* \\
* \\
* \\
*\end{array}$ & $\begin{array}{l}* * \\
* * \\
* * \\
* *\end{array}$ & $\begin{array}{ll} & * \\
* & * \\
* & * \\
* & * \\
* & *\end{array}$ & $\begin{array}{l}* \\
* \\
* \\
* \\
* \\
* \\
*\end{array}$ & 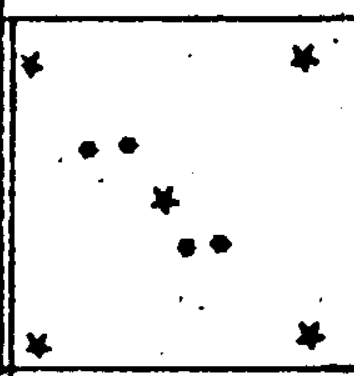 & $\stackrel{*}{*}$ & $\begin{array}{ll}0 & 0 \\
0 & 0 \\
\infty & 0 \\
N & 0 \\
1 & 0 \\
1 & 0 \\
0 & 0 \\
0 & 2 \\
N & 2\end{array}$ & 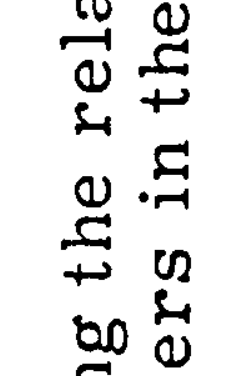 \\
\hline$\because$ & $*$ & 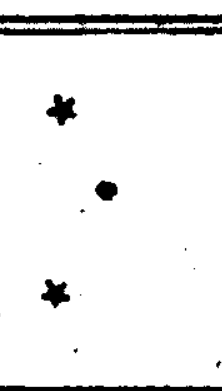 & $*$ & 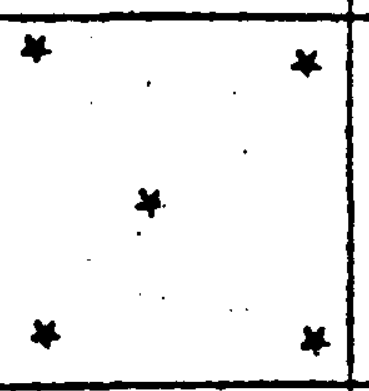 & $\begin{array}{l}* \\
* \\
* \\
*\end{array}$ & $\begin{array}{ll}* & * \\
* & * \\
* & * \\
* & * \\
\end{array}$ & $\begin{array}{l}* \\
* \\
* \\
*\end{array}$ & $\begin{array}{l}* \\
* \\
* \\
* \\
* \\
\end{array}$ & $\begin{array}{l}*: \\
\because:\end{array}$ & 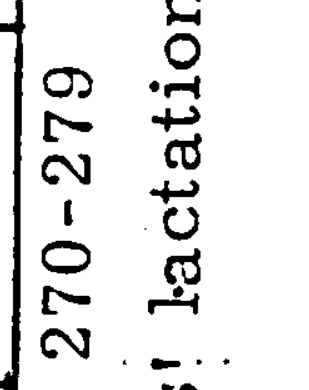 & 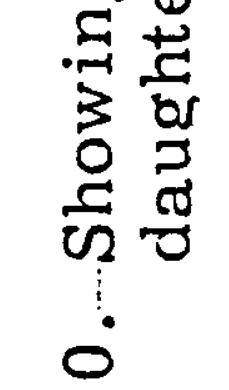 \\
\hline$\dot{.}$ & 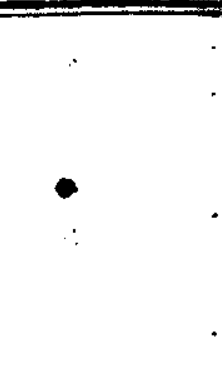 & . & * & ${ }^{*}$ & $\begin{array}{l}* \\
* \\
* \\
*\end{array}$ & $\begin{array}{l}* \\
* \\
*\end{array}$ & *: & * & $\begin{array}{l}* \\
\cdots \\
*\end{array}$ & $\begin{array}{ll}0 & 0 \\
0 & c \\
0 & 0 \\
N & 0 \\
1 & 0 \\
1 & 0 \\
0 & m \\
0 & 0 \\
v & 0 \\
N & \infty\end{array}$ & 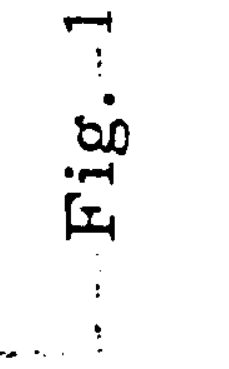 \\
\hline
\end{tabular}


3. Month of calving: In order to determine the part played by heredity in milk yield and fat percentage, one must put in account the month of calving of both dam and daughter under somparison, as a component of the variation caused by environment. Keestra, and Bakhoven (1931), studied the influence of the month of calving of 45573 Friesian controlled cows in Friesland, during the period 1927-28. They found that most of the calvings in Friesland occurred during the two months of Feb. and March, and secondly in April. This indicates that most of the farmers prefer, owing to the economic feeding conditions, to get their cows' productions during the green season.

Figure 11, as illustrated from Keestra-Bakhoven's work, shows clearly the distribution of month of calving in their material.

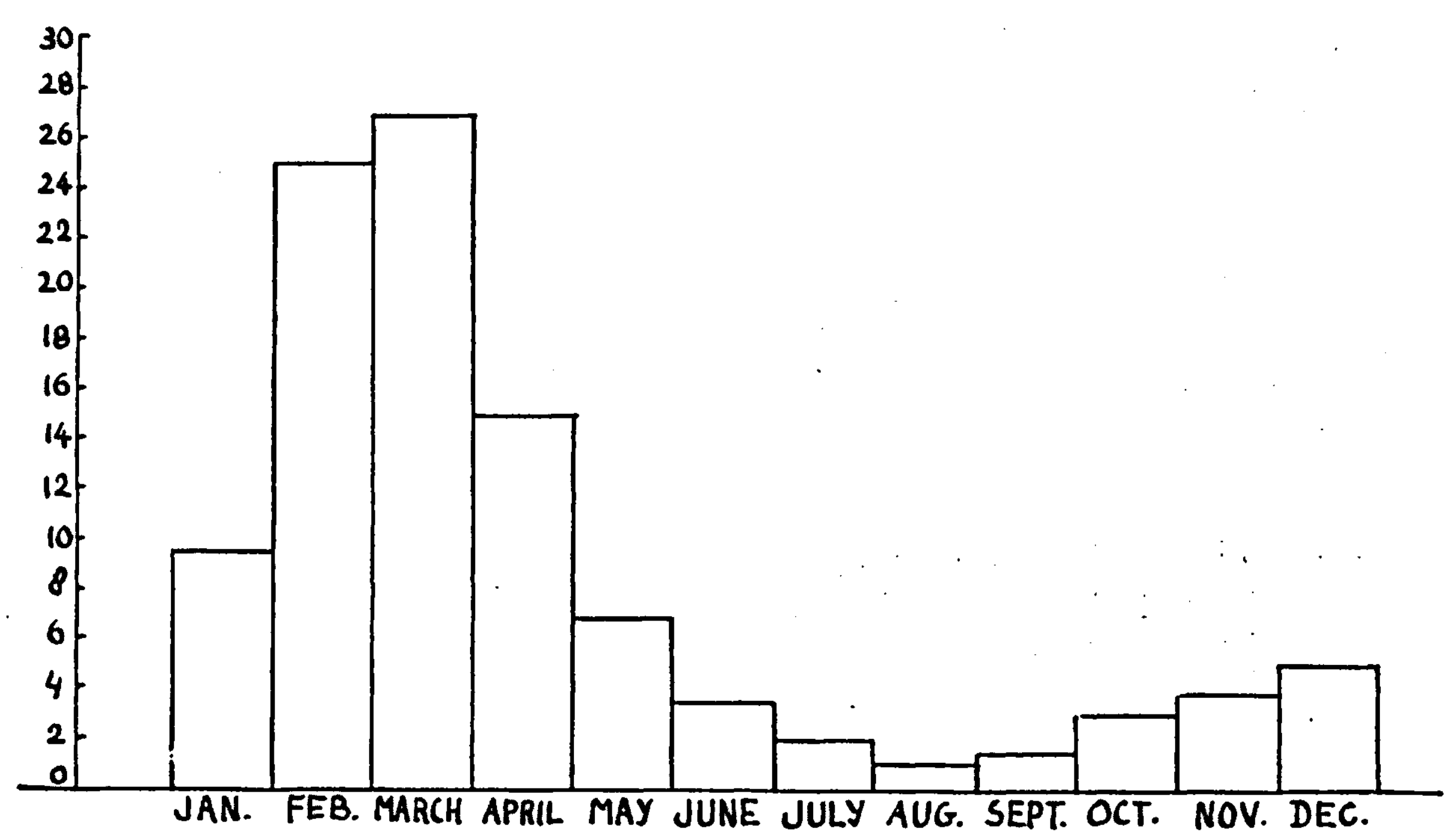

Fig. 11. The percent distribution of month of calving of 45573 Friesian colvs in Friesland - during 1027-'28.

This result they got, is in accordance with that I got from my material, and which was shown in figures 5,6 and 7 .

Keestra and Bakhoven in their study, found that the lactation periods of cows which calved during the months of March, April, May, June and July, were, on the average, shorter by 20 days, than those which calved during the other months of the year. The longest periods were those of cows that calved in September and October. It seems to me rather reasonable that in the latter case the next heat periods of some of the cows that calved late in autumn, were short during the cold weather, and were not recog- 
nized by the farmers. Such cows which did not succeed to be bred in early winter, were usually kept to be bred during next May. Such cows the farmers kept in lactation as far as their production paid the extra costs of winter feeding. Moreover, the milk price in winter is higher.

The influence of the month of calving over the production of milk and the fat percentage, is shown in figure 12. From this figure, Keestra and Bakhoven found that the highest production was attained during the months of calving of September, October, and November. They concluded that if the farmers spread the months of calving in their material equally over the year, the average production per cow should be $150 \mathrm{kgs}$ milk higher (about $33 / 4 \%$ ) and $\pm 0.02 \%$ fat (about $1 / 2 \%$ ) higher.

Figure 12, as illustrated from Keestra-Bakhoven (1931), shows the effect of the month of calving on: 1. the lactation period. 2 . the average fat percentage, and 3 . the average milk yield.

Plum (1935) showed that the season of calving contributed $3 \%$ to the total variation in yield.

Figures 5, 6, and 7 showed the great similarity in the occurrence of most cases of the month of calving in the material studied; and no reason was found sound enough to use correction factors to standardize the effect of the month of calving in the present data. It is not expected that, under the conditions of the material, the heritability estimates were significantly highly affected by the contribution of the month of calving on the production records of the material.

4. Effect of feeding conditions: Many experiments have been carried out to demonstrate the effect of feeding level on milk and butterfat production. Wing, and Foord (1904) found that liberal feeding to a poorly fed herd, would increase milk and fat production up to $.50 \%$. Keestra and Bakhoven (1931) in their study of the Friesian cattle in the province of Friesland, found greater differences between the milk yield in summer and winter on the pasture farms, compared with the mixed farms. This can be easily attributed to the fact that on the mixed farms, the farmer can store roots and by products of his farm, to feed them to his cows in winter time, whereas the farmer on the pasture farms has not the same possibilities. Jensen et al (1942) from!data gathered over 3 years from 10 experimental stations, found that about 15$20 \%$ more milk was obtained from levels above the commonly standard.

Increasing the level of feeding raised the milk yield, but had no effect on butterfat percentage. This gives another evidence that fat $\%$ is more governed by heredity, and consequently less affected by environment than milk yield. Ragab, et al (1954) showed that buffaloes calving in Egypt in the months of February and March, were the best yielders, and their relative yields went up to 116 and $114 \%$ for the two months respectively. This was due to the fact that the green fodder in Egypt, (Trifolium Alexandrinum), is only available during the late autumn and winter seasons (Nov. May). For the same reason, Ragab, et al (1954) found that the Egyptian cow that calved in November, showed the highest milk yield. 
Days

320 The relation between month of calving

315 and lactation period.

310

305

300

295

290

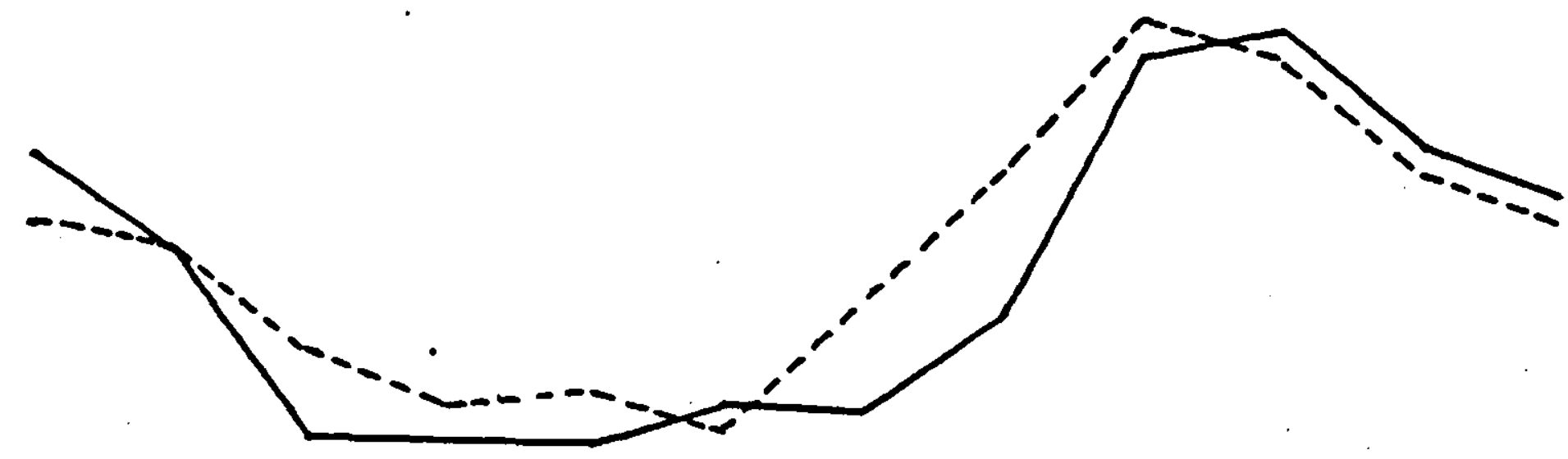

285

$\%$ Fat

3.65 The relation between month of calving

3.60 and mean fat percentage.

3.55

3.50

3.45

K. G.

4800 The relation between month of calving

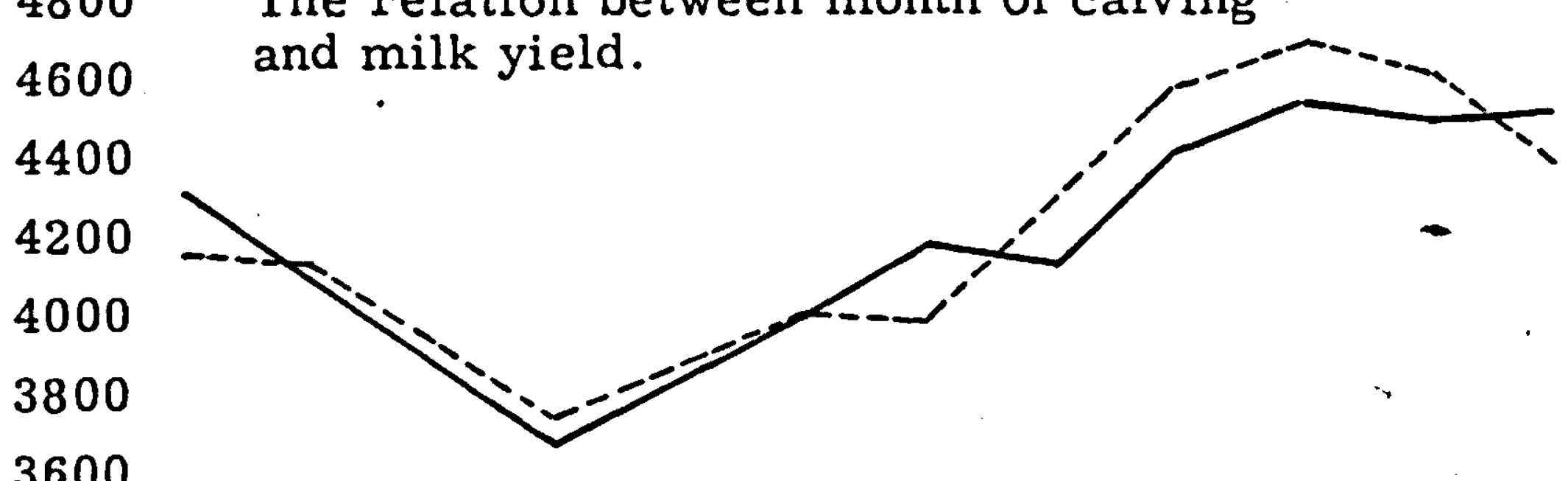

3600

JAN. FEB. M. APRIL MAY JUNE JULY AUG. SEPT. OCT. NOV. DEC. 1927 (23624 cows) 1928 (21949 cows)

Fig. 12. As illustrated from Keestra and Bakhoven (1931) 
In Friesland cows are not forced to give high yields. The farmer always aims at the attainment of high average output by good and economical feeding. It is clear from figures 5, 6, and 7 , that most of the farmers preferred to have their cows to calve during Feb., March, and April, so that most of the production could be gained on green fodder.

As it was said before in the "Material", the soil of the province of Friesland is composed of clay, peat, and sand. As feeding conditions differ slightly according to the three kinds of soil, the animals serving this research work, were grouped within sires in accordance with the kind of soil they were kept on. Berry and Lush (1939), and Lush, et al (1941), pointed out that the omission of a record known to be made under abnormal circumstances for which adequate correction cannot be made, might increase the value of the results. In the present study, apart from the period of war, the omission was applied to those records following abortion, or where the records carried the notation of serious illness or accident during the lactation.

From the conditions mentioned in the "Milterial", mostly the daughter-dam pair under comparison, was kept in one herd during the production studied. Most of the investigation was confined to bulls which had a very high number of daughters. That naturally increased the proportion of cases where some of the dams and daughters were kept in one herd, while. others were kept in another where the conditions of feeding differed. This would have contributed an environmental portion to the daughter-dam correlution. An other effect would have happened if there was any general tendency for the owner to give a daughter better feeding than the average of the other daughters in his herd, and her dam better environment than the average of the other dams. Such a correlation between the environments of daughter and of dam, would have contributed a non-genetic portion to the correlation between the records of daughters and dams. We find no method for testing these data, to learn whether such environmental correlation did exist; but in view of the feeding and managements practice in Friesland; i. e., in the present material, most of the yields were obtained in the green time where cows of different herds fed almost only grass. That gave a great portion of similarity in their management, (although the nutritional value of grass, differs more or less from soil to soil); we think that such environmental correlation must have been in most cases of our study, very small to contribute much to our estimates of heritability.

5. Effect of temperature: Zeller (1951) found that the /warmer the environment, the lower the butter fat content, and the colder the environment, the higher the butterfat content of the milk. Fluctuations of as much as $1 \%$ were observed; whereas milk yield was seldom affected. In the present investigation, the cattle were on the pasture six months per year (from about April, till October). During this period, the temperature rarely reached the degree that affected the yield of the cows. During the six months of winter time, the cows were kept indoors.

Figure 13, shows the average degrees of temperature over the 
whole year, in the province of Friesland, where the data were collected. It is note worthy to say, that the weather conditions are naturally even over the whole province, so that one should not expect any great influence from this point on our present results of the research.

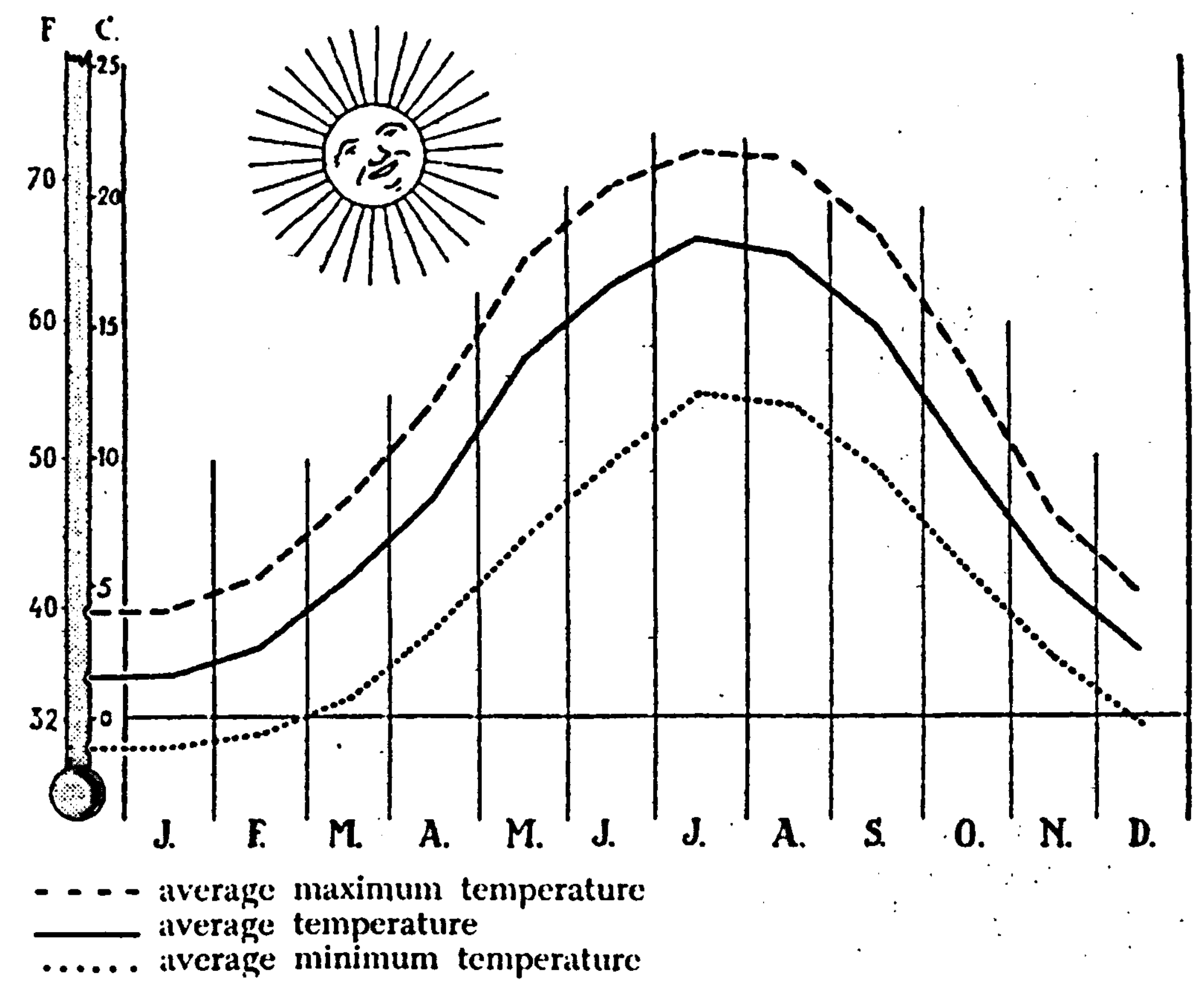

Fig. 13. The average temperature in the different months.

6. Number of records needed: Lush and Strauss (1942) stated that in averages of two or more lactations per cow, the differences due to circumstances which change from lactation to lactation, will tend to cancel each other, thus decreasing the environmental variance, but leaving the genetic variance unchanged. In their study, they used dams with 3.15 average records, and daughters that yielded 1.68 average records. For comparing those findings with others, and for making them useful for generalizing to cases where each cow has " $n$ " records, they used a special formula to express the findings in terms of what they would be if each cow had only one record. Putman, et al (1943) made a comparison of the use of the first records versus the average of all records in dam-daughter comparisons. The comparison of those data for 169 Ayrshire sires, and 3388 dam-daughter pairs, showed that there was only a very small and insignificant difference in the results obtained by the two methods. The first records comparisons averaged slightly higher than the averages 
of all records. They suggested that a real saving can be made in the labour required to report dam-daughter comparisons by using first records only.

In estimating. the heritability of milk yield and fat percentage from dam-daughter comparisons in the present investigation, from the results obtained for each of the first three lactation periods, the average value of heritability was worked out.

This is a better method than comparing averages of unequal weights, standardized by any means to one record. The spreading out of the records over different years, had more chance to cancel the differences in feed or management from one year to another in the records of both dams and daughters under comparison in this study.

The average milk yield in 310 days in each of the three lactation periods of the animals under study, and in accord to groups owing to the kind of soil, is shown in table 9 . Table 10 shows the corresponding fat percentage tests for the same cows.

From table 9, the averages of $\mathrm{kgs}$. of milk produced in 310 days for the groups reared on clayey, peaty, and sandy soils, were as follows: first lactation, $3442: 55,3375.90$, and 3298.40 ; second lactation 4276.45, 4132.30, and 4123.55; third lactation 4851.50, 4628.30 , and 4650.0 , respectively. The average milk yield over all the province within the animals studied was, 3413.10 for the first lactation period, 4237.70 for the second, and 4794.15 for the third period. It is clear from the results obtained that the milk yield obtained on the clayey soil was slightly higher than that obtained on the peaty, and that the milk yield on the latter, except in the third lactation, is insignificantly higher than that on the sandy soil. That is due to the fact that on the clayey soil, the land offers better feeding than in the case of sandy and peaty soils. So one can safely say that different standards of feeding according to the condition of agriculture practiced in each kind of soil, caused such differences in production. For this reason it was reasonable enough to group the animals in this investigation according to the kind of soil kept on, as it is mentioned in the "Material".

The average heritability estimates of milk yield as obtained from within groups, within sires, and according to different kinds of soil, were, $35.50 \%$ and $37.36 \%$, (see table 3 ), as obtained from daughter on dam regression, and dam-daughter correlation methods, respectively. When the effect of different soils was neglegted, the effect of variability of different feeding conditions appeared in the results. The estimates, as shown in table 3 , were $36.58 \%$, and $38.60 \%$, for the two methods of comparison respectively.

It is for the purpose that cattle feeding conditions differed widely; i.e., some feeding concentrates during the green time, and some had enough grass; and also for the reason that milk yield is not highly heritable but is affected greatly by feeding conditions, that it can be concluded that the results of the estimates of heritability of such a character, as calculated from groups of cattle kept on those different conditions, should contain some of the variability caused by environmental conditions. The results which are shown in table No. 3 confirm this conclusion. 


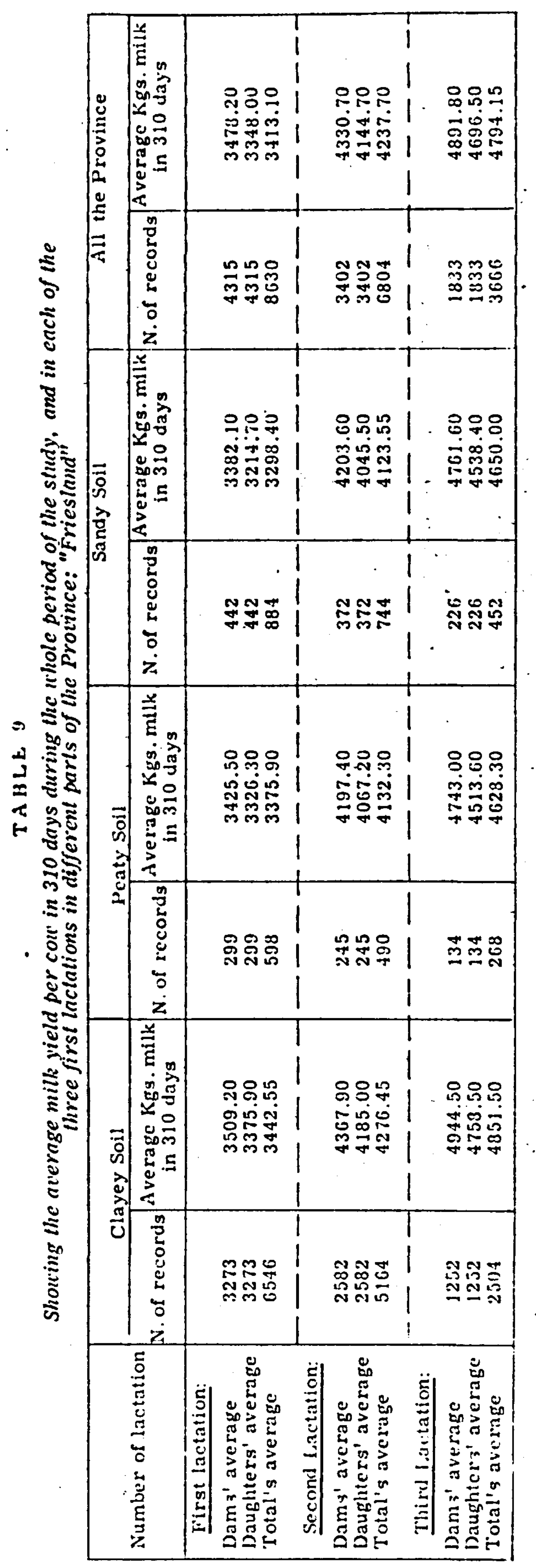




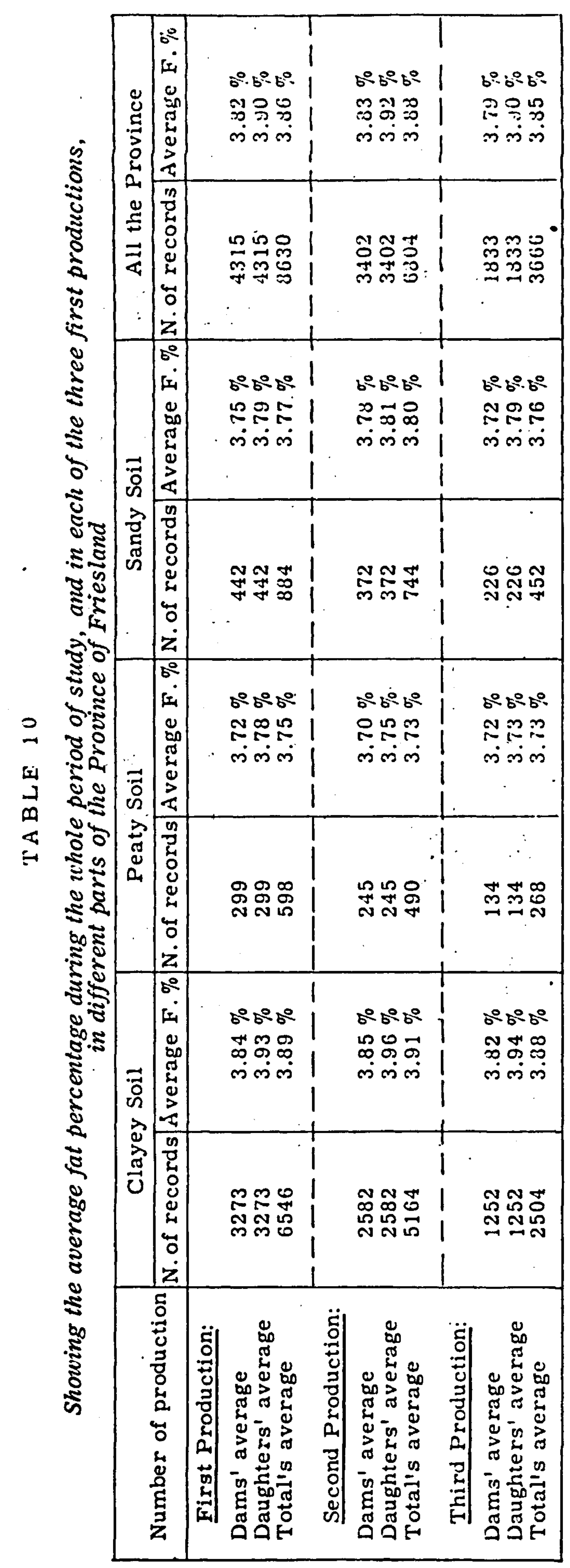


The estimates as obtained from groups on clayey, peaty, and sandy soils were $34.74 \%, 38.88 \%$, end $38.48 \%$, basing the calculations on daughter-on-dam regression method.

The same estimates as calculated from daughter-dam correlation method were, $36.80 \%, 41.84 \%$, and $38.22 \%$ respectively.

For the same purpose mentioned in the last part of the discussion, the heritability estimates of fat percentage differed as well as the average fat percentage tests. From table 10 , the average fat percentage tests for the groups kept on clayey, peaty, and sandy soils, were as follows: first records, $3.89 \%, 3.75 \%$, and $3.77 \%$; second records, $3.91 \%, 3.73 \%$, and $3.80 \%$; third records, $3.88 \%$, $3.73 \%$, and $3.76 \%$, respectively. The average fat percentages over all the province within the animals studied were, $3.86 \%, 3.88 \%$, and $3.85 \%$ for the first, second, and third production periods respectively. It is clear from the results that the average fat percentage within groups kept on clayey soil was slightly higher than that obtained from those kept on sandy soil, and that the fat percentage obtained from the latter groups, was on the average higher than that obtained from those groups kept on peaty soil.

The average heritability of fat percentage as obtained from within groups, within sires, and according to different kinds of soil, were, $76.52 \%$ and $81.58 \%$, as calculated from daughter on dam regression, and dam-daughter correlation methods, respectively. When the effect of different soils was neglected, the results were $76.40 \%$, and $81.60 \%$ respectively. It seems from the results obtained, and shown in table No. 7 , that the fat percentage is much more heritable than the milk yield, and correspondingly, the former character is less affected by environmental conditions than the latter. The estimates of heritability of fat percentage obtained from groups reared on clayey, peaty, and sandy soils were, $77.52 \%, 70.88 \%$, and $73.36 \%$, when the calculations were based on daughter on dam regression. The same estimates as calculated from doubling the dam-daughter correlation were, $83.42 \%, 76.92 \%$, and $72.04 \%$.

From table 9 , on the average it is shown that the milk yields attained in 310 days, for dams under the conditions of this investigation, were higher than the corresponding yields of their daughters. This could be attributed to one or more of the following reasons: -

1. Cows selected in practice as dams, were on the average higher

in respect of their yields. This was proved to be right in the data of the present research. Figure No. 14, which was worked out from the first lactations of the daughters and dams in this study, shows that there was a tendency for slight selection on the side of the dams.

The test of Skewness, (see chapter 4), showed significant $g_{1}$ of $+0.434 \pm 0.037$ in the frequency distribution of the dams' first milk yields, whereas the corresponding $g_{1}$ for daughters' yields were $+0.226 \pm 0.037$. In the two cases, the curves were steeper. on the left sides where the lower productions were situated.

The higher asymmetry in the case of the dams' yields graph, demonstrates a conclusion that the dams were higher selected than their daughters, with regard to their production records. 
The slighter skewness in the case of the daughters' graph may indicate that some selection was practiced too, but to a less degree than in the case of the dams. This very slight selection might have occurred from culling the unsatisfactory yielding daughters, before they had the chance to close their first records.

2. From figures $8, \therefore 9$, and 10 , it is clear that on the average, the

lactation periods of daughters under investigation, were a litthe longer than the similar periods of their dams under comparison: As the criterion to get the average milk yield in 310 days was to multiply 310 by the average milk yield per day for each cow, this figure could be affected by the lactation period length; i. e. the longer the period, the smaller the average milk yield per day, as compared with that gained from shorter period, under the same genotypic and environmental conditions.

3. Moreover, the phenotypic selection to improve the two characters (milk yield and fat percentage) could be highly effective in the case of fat percentage in contrast to milk yield. The reason is simply gained from the fact that the fat percentage is a highly heritable character, while the milk yield is a low one.

4. Another reason is that selection in Friesland was strongly directed towards fat percentage. Around 1900 came the industrial manifacturing of dairy products, and the dairy plants had been established. After that, most of the farmers passed on to deliver their milk to those plants. Owing to the differences between the fat content of the milk which milk plants received, it was arranged that all milk was paid on a basis of fat content, besides the grade of the milk. Owing to that, the farmers directed their selection towards keeping animals yielding high fat in their milk. The results were as shown by De Jong (1947). He reported that in the period 1912-16, the average fat percentage in the milk of the Friesian cows in Friesland was $3.26 \%$. He added that during the period 1935-1939, the average fat percentage amounted to $3: 78 \%$, in the milk of the cows registered in the Friesian Herdbook, during that period. Kramer (1953) said that, "it will be clear that this way of payment based on fat content (in the Netherlands), has importantly influenced, and is still influencing the breeding of cows with a high yield of fat".

Kř́ženecký (1933) found a negative correlation between milk yield and fat percentage in the order of -0.1988 to -0.1842 . The same author (1934) with a material from Red Danish, Black-\& White Friesian, Black-\&-White Dutch, East Finnish, West Finnish, Finnish Ayrshire, Swedish Red Polled, Black-\&-White Swedish, Swedish Ayrshire, and Bohemian breeds, made a study of the correlation between milk yield and fat. He concluded that there was a negative but insignificant correlation between milk yield and fat percentage, as compared with possitive correlation between milk yield and fat yield. The two correlation coefficients were -0.1771 and +0.9379 respectively. Podhradský (1940) from a study of the production of Bernese cattle in Moravia, reported that no correlation existed between milk yield and fat percentage. Solovjëv (1940) found a negative correlation of $-0.399 \pm 0,01$ between daily milk yield and fat percentage in the milk of 21 simmental cows. De Jong (1947) stated that Bakhoven mentioned that when he exa- 


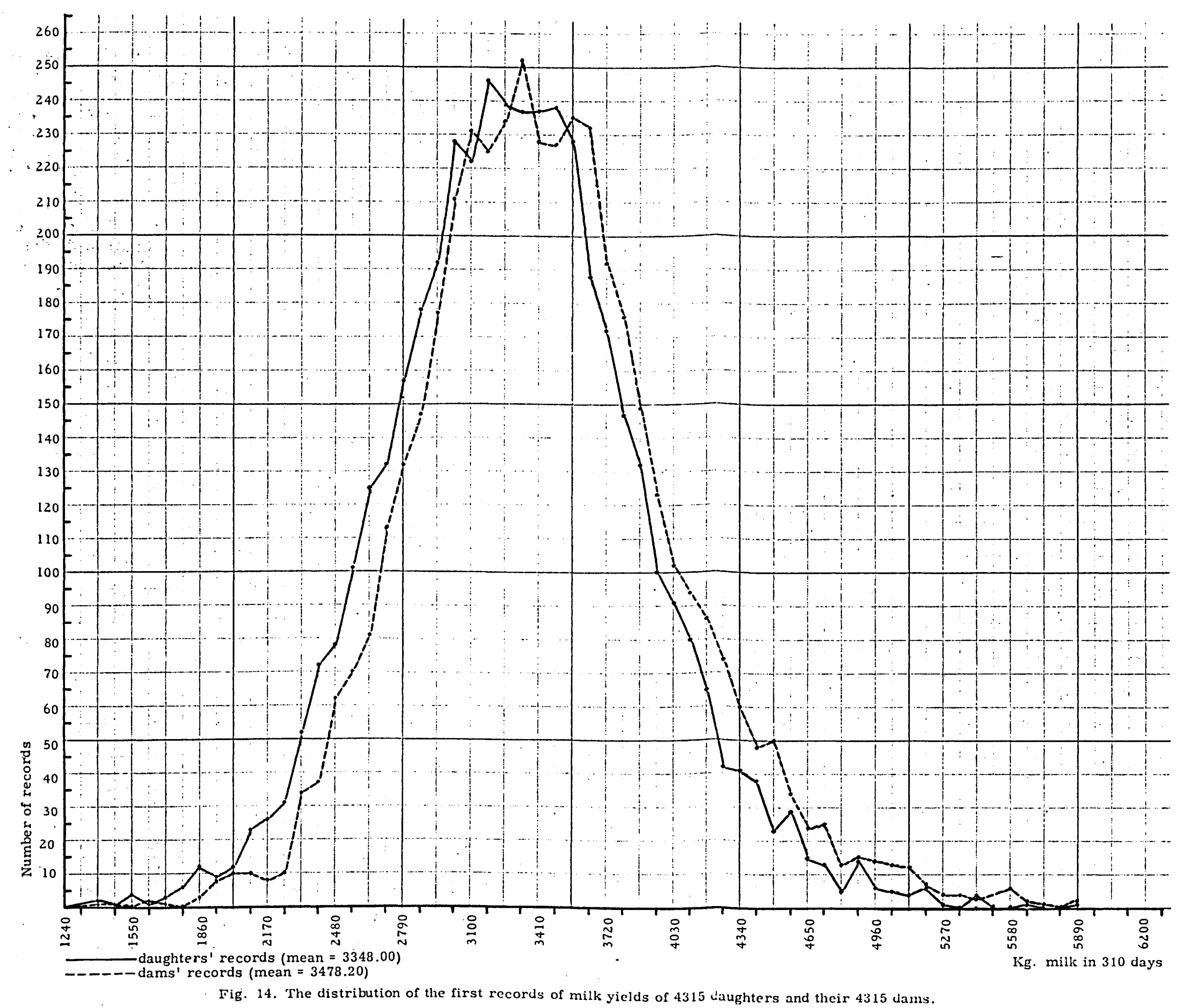


mined random samples of the cows registered in the Friesian Herdbook in Friesland, he found that there was no clear negative correlation between milk yield and fat percentage, but the animals with low milk yield and low fat yield were not many, because they were mostly culled. The primary investigation of the records of the present study did not indicate a clear negative correlation to exist between milk yield and fat percentage, and another investigation is needed to clear up this point.

It is now said that recently the farmers in Friesland chose to increase butterfat yield by increasing milk yield, and that most of them now, when they get the fat percentage in the milk of their cows around $4 \%$, begin to direct all their attention towards improving the milk yield.

\section{Heritability Estimates}

Regression is to be preferred to correlation between dam and daughter in data like those in the present study, because the dams had been somehow selected. Lush and Strauss (1942) concluded from a similar study that "doubling the intra-sire regression of daughter's records on dam's records, seemed the most dependable method for estimating the heritability in data like these, where the sire cannot express the characteristic himself, where the dams were likely to have been a bit more highly selected than daughters, and especially because feeding and other management practices were almost certain to have differed considerably from herd to herd". Therefore, one can say that the estimates of heritability obtained from the daughter-on-dam regression, in the present study, are nearer to reality than those obtained from doubling the dam-daughter correlation coefficients.

The regression of daughters' records on dams' records within groups of offspring by the same sire, should eliminate most of the environmental, dominance, and epistatic contribution to the correlation between parent and offspring. It would be expected in such comparisons that the standard deviation of the dams' records $(\Sigma x)$, would be lower than the statistic $(\Sigma y)$ for daughters' records, because in the present study the dams were to some extent a selected group (see figure 14). Moreover, according to the fact that daughters are in the same sire progeny, half sisters, whereas the dams may be from several different sires, this tends to reduce $(\Sigma y)$ relative to $(\Sigma x)$. That was why the estimate obtained by daughter-on-dam regression method, on the average, less than the corresponding estimates gained by dam-daughter correlation method.

If we compare the results obtained in this study, with those obtained by different investigators mentioned in the literature, we find that most of the estimates of heritability of milk yield were $30-40 \%$, while those of fat percentage were $60-80 \%$. Our results obtained through regression method were, $35.5 \%$ for milk yield, and $76.52 \%$ for the heritability of fat percentage. The corresponding heritabilities as estimated from dam-daughter cor- 
relation method were $37.36 \%$, and $81.58 \%$ for the heritability of the two characters, in the same respect.

Sampling errors, dominance, epistatic deviations, or selective mating, or any other non-heritable conditions, may have some effect on the estimations usually reached at as measurments of he ritability.

The Mendalian errors that come from segregation which permits gametes coming from sires and dams to contain different genes, tend to cancel themselves as the case in the present study, where the number of pairs under comparison increases. Mather (1949 p. 134) mentioned that in plants, the size of comparisons "is not to be reduced below, say 10 or 15 individuals". In the present study the number of comparisons within each sire group ranged between 15 to 84 dam-daughter pairs. This gave more chance to cancel the Mendalian errors.

Although some investigators mentioned breed differences to exist in the amount of the heritability of characteristics, it cannot be rightly said without standardizing all the methods, numbers, and circumstances under which the estimates are carried out. The present study does not indicate direct comparatively results with others, unless the latter are done under similar conditions, and with a similar number of comparisons.

When the whole material was studied as a homogeneous population, rather than on an intra-sire basis, as was done in tables 3 and 7 , the correlations and regressions were as shown in tables 4 and 8 . The heritability estimates attained at in the latter two tables, by doubling the correlation and regression coefficients were on the average significantly higher than the corresponding ones measured through intra-sire basis. The heritability estimates as averaged within sires, within groups, were, $35.5 \%$ and, $37.36 \%$ for milk yield, and $76.52 \%$ and $81.58 \%$ for fat percentage, as calculated from the regression and correlation methods respectively. The estimates attained at assuming homogeneous population were, $39.60 \%$ and $40.60 \%$ for milk yield, and $84.44 \%$ and $83.52 \%$ for fat percentage, for the two methods in the same respect.

Most of the differences found between the estimates obtained within sires, and those from the treated material assuming homogeneous unit, must be due to larger sire group to sire group heterogeneity in feeding and management. In the case of fat percentage estimates, where the differences proved to be on the average, very highly significant, a great part of this difference can be attributed to assortive mating that probably had been practiced according to the character of fat percentage. Genetic heterogeneity is not wholly excluded, and may have interfered with those differences; but on the other hand, owing to the fact that in the last century, breeding the Friesian cattle in the province of Friesland, was always closed, all the blood appeared to belong almost exclusively to one or two main ancestors. If in such a way inbreeding was practiced, one would expect some degree of genetic homozygosity between the sires and mates used in the present study. This point needs more study, since no attempt, till now, was made to measure the amount of inbreeding used in the Friesian cattle, in the province of Friesland. 
In this study, the estimates of heritability obtained from the regression of daughters' records on dams' records, within groups of offspring by the same sire, and according to the kind of soil the animals were reared on, are nearer to reality than those obtained from the other trials. The results of estimates of that method showed that about $35 \%$ of the observed variation in milk yield, and about $76 \%$ of the observed variation in fat percentage, were due to heredity; and that thus about $65 \%$ and $24 \%$ of the observed variation of the two characters respectively, were due to non-genetic factors. This indicates that fat percentage is highly heritable, and can be improved by the application of phenotypic selection. If the mass selection is practiced for the purpose of improving milk yield, the character will also improve at a slower rate, as compared with the improvement gained by paying more attention to genotype, basing the selection on pedigree and progeny testing.

Since genetic differences can be followed only by their effects on the phenotype, the means of detecting the amount of these effects will be limited, since in the case of low heritable characters like milk yield, we can reduce only the non-heritable variation, but till now there is no way to eleminate it all.

As is shown from the results in tables 9, and 10, there was a tendency for milk yield to decrease towards the average while the fat percentage was improving. We have no means to predict the mechanical and physiological relations between the genes responsible for milk yield, and those responsible for fat percentage. This means that the ideal method to improve both characters at the same time, has not been found yet. We hope that in future we can have a fuller understanding of the problem, to have a greater control over the practical use of applying statistical methods in improving the se two economical characters. 


\title{
Chapter VIII
}

\author{
SU M M A R Y
}

This work was carried out to measure the heritability of milk yield and fat percentage of the herdbook cattle in Friesland, using daughter-dam cows comparisons, and without the use of correction factors. Data were collected from the books of the Friesian Herdbook cattle society in Friesland since 1920 with the period 1940-1947 excluded. A total number of 9550 pairs of daughter-dam records, within sires that were only used on normal services, were introduced in the comparisons, firstly for correlations, and secondly for regressions, in order to estimate the heritability of milk yield. The same records were used in the calculations for the heritability of fat percentage. The comparisons covered the first three lactation periods. The daughter-dam pairs introduced in each case were distributed on the three lactation periods as follows: 43 i5 daughter-dam pairs within 117 bulls for the first period; 3402 pairs within 104 sires for the second period; and 1833 pairs within 65 bulls for the third production period.

The average number of pairs in each comparison within sire was 36.9 daughter-dam pairs, with a maximum of 84 , and a minimum of 15 pairs for the first period, with respective. number of 31.8 pairs and $73-15$ for the second period; and 28.2 daughter-dam pairs, and 55-15 for the third production period, in the same respect. The average milk yield per day as calculated from normal lactations with periods of 260-360 days, was taken as a criterion in the comparisons of milk yield. The difference of age between each daughter and her dam in the corresponding lactation, did not exceed 6 months. The groups within each sire were divided into three categories owing to the kind of soil the animals were kept on. Under the conditions of the material, the analysis showed the following:

1. The average milk yield in 310 days in each of the first three lactation periods of the animals under study was; first lactation; 3443, 3376, and 3298; second lactation: 4276, 4132, and 4124; third lactation: 4852,4628 , and 4650 , Kgs. milk respectively for the groups of cows kept on clayey, peaty, and sandy soil. For fat percentage, the corresponding figures were: $3.89 \%, 3.75 \%$, and $3.77 \% ; 3.91 \%, 3.73 \%$, and $3.80 \% ; 3.88 \%, 3.73 \%$, and $3.76 \%$, in the same order as mentioned in the case of milk yield.

2. The average heritability estimates of milk yield as obtained

from groups, viz. within sires, and according to the different kinds of soil, were $35.5 \%$ and $37.36 \%$, as computed by doubling the regression of daughters' records on dams' records and the dam-daughter correlation respectively. Under the same condi- 
tions, the average heritability of fat percentage was $76.52 \%$ and $81.58 \%$ in the same respect.

3. When the effect of different soils was neglected, the average heritability estimates for milk yield were $36.58 \%$, and $38.60 \%$ as obtained from caughter on dam regression, and dam-daughter correlation methods respectively.

The corresponding figures for fat percentage.were: $76.40 \%$, and $81.60 \%$, respectively.

4. When all the data were studied as a homogeneous population, rather than on an intra-sire basis, the average heritability estimates for milk yield were: $39.60 \%$, and $40.60 \%$; where as for fat percentage the estimates were: $84.44 \%$, and $83.52 \%$, as computéd from daughter-on-dam regression, and dam-daughter correlation methods respectively.

The : most true heritability estimates in this study are those obtained through 'the daughter-on-dam regression method from groups, within sires, and according to the different kinds of soil. So, the conclusion is that about $35 \%$ of the observed variation in average milk yield per lactation, and about $76 \%$ of the variation in average fat percentage of the Friesian herdbook cattle, are due to heritable differences, whereas the remaining part of the variation can be attributed to non-hereditary causes. 


\section{SA MENVATTING}

Dit onderzoek werd verricht om de erfelijkheidsgraad $\left(h^{2}\right)$ van de melkopbrengst en het vetgehalte bij het stamboekvee in Friesland te bepalen. Hierbij werd de methode de'r dochter-moedervergelijking toegepast, zonder gebruik te maken van correctiefactoren.

De gegevens werden verzameld uit de boeken van het Friesch Rundveestamboek vanaf 1920 , met uitzondering van de jaren 19401947. In totaal werden 9550 lijsten van dochters met die van haar moeders vergeleken om zowel de correlatic- als de regressiecoëfficient te berekenen, teneinde de erfelijkheidsgraad voor de melkproductie te bepalen. De dochter-moedervergelijking werd steeds uitgevoerd binnen groepen dochters van écn natuurlijk dekkende stier. Dezelfde lijsten werden gebruikt om de erfelijkheidsgraad voor het vet gehalte te berekenen.

Voor elk der drie in het onderzoek betrokken lactatieperioden waren de aantallen de volgende: Voor de eerste 4315 dochters van 117 stieren, voor de tweede 3402 van 104 stieren en voor de derde 1833 dochters van 65 stieren.

Per stier werden gemiddeld 36.9. dochters met haar moeders vergeleken, variërende van 84 tot 15 voor de eerste lactatieperiode; voor de tweede waren deze aantallen 31.8 (variërende van 73 tot 15 ) en voor de derde 28.2 (variërende van 55 tot 15 ).

Voor de vergelijkingen van de melkhoeveelheid werd uitgegaan van de gemiddelde dagopbrengst, berekend uit normale lactatieperioden van 260 tot 360 dagen. Het verschil in leeftijd tussen een dochter en haar moeder. bedroeg voor eenzelfde lactatieperiode maximaal 6 maanden.

De dochters van elke stier werden in drie groepen verdeeld naar de grondsoort waarop de dieren werden gehouden.

De resultaten van het onderzoek kunnen als volgt worden samengevat:

1. De gemiddelde melkgift in 310 dagen van de bij dit onderzoek

betrokken dieren bedroeg op klei-, veen-en zandgrond voor de eerste lactatieperiode resp. 3443,3376 en $3298 \mathrm{~kg}$; voor de tweede lactatieperiode resp. 4276,4132 en $4124 \mathrm{~kg}$ en voor de derde lactatieperiode resp. 4852,4628 en $4650 \mathrm{~kg}$. Voor het vetgehalte waren de cijfers in dezelfde volgorde: $3.89 \%, 3.75 \%$ en $3.77 \% ; 3.91 \%, 3.73 \%$ en $3.80 \% ; 3.83 \%, 3.73 \%$ en $3.76 \%$.

2. De berekening uitgevoerd binnen de groepen halfzusters en te-

vens binnen de groepen naar grondsoort gaf door verdubbeling van de dochter-moeder-regressie een erfelijkheidsgraad van $35.5 \%$; werd de correlatie-coëfficient tussen moeders en dochters met twee vermenigvuldigd, dan werd $37.36 \%$ gevonden. De op dezelfde wijze berekende erfelijkheidsgraad voor het vetgehalte bleek in dit geval $76.52 \%$ resp. $81.58 \%$ te zijn.

3 . Als geen rekening werd gehouden met het verschil in grond- 
soort dan leverde de regressie-methode een gemiddelde erfelijkheidsgraad voor de melkhoeveelheid op van $36.58 \%$, de correlatie-methode van $38.60 \%$. Voor het vetgehalte waren in dit geval de cijfers resp. $76.40 \%$ en $81.60 \%$.

4. Als alle gegevens werden beschouwd als te zijn afkomstig uit én homogene populatie, dan werd als gemiddelde erfelijkheidsgraad voor de melkhoeveelheid $39.60 \%$ (regressie) en $40.60 \%$ (correlatie) gevonden, terwijl voor het vetgehalte dan de waarden $84.44 \%$ resp. $83.52 \%$ werden.

De meest juiste waarden van de erfelijkheidsgraad voor melkopbrengst en vetgehalte van het in dit onderzoek bewerkte materiaal zijn die, welke hierboven onder (2) worden aangegeven.

De conclusie is dus, dat ongeveer $35 \%$ van de gevonden variatie in gemiddelde melkproductie per lactatie en ongeveer $76 \%$ van de variatie in gemiddeld vetgehalte bij het Friese stamboekvee een gevolg zijn van erfelijke verschillen, terwijl de rest van de variatie moet worden toegeschreven aan niet-erfelijke oorzaken. 
Anonymous (N.d.) Preferente stieren in Friesland 1910-1932, Leeuwarden Provinciale commissie voor de veefokkerij in Friesland: 76.

Axelsson, J. , 1933.

Det arrftliga inflytandet på kronas mjolkavkastning. Tidsskr. Avelsforr. Svensk R. V. Bosk., No. 4: 12.

$-\cdots-\cdots-\cdots, 1934$.

(Uppsala.) Ett fortsatt forsరk till avkommeunders $8 \mathrm{kning}$ inom lågladsras. Nordisk Jordbrugsforsk., 15 : 371-402.

Bakhoven, A. Leignes, 1948.

De beoordeling der melkproductiegegevens, Landbouwkundig Tijdschrift, $60: 25-29$.

Bas, J. A. de, 1936.

De bepaling der melkproductiewaarden van runderen. Proefschrift - Utrecht.

Bartlett, J.W., Pfau, K. O., and Tucker, H. H., 1934. The inheritance of high butter-fat percentage in Holstein-Friesian cattle. New Jersey Agric. Exp. Sta. Bull, No. $572: 16$.

Bekedam, M., 1954.

Het bepalen van de melkproductievererving bij stieren. (Unpublished data).

Beardsley, J. P., Bratton, R. W., and Salisbury, G. W., 1950.

The carvilinearity of heritability of butterfat production.

J. Dairy Sci., 33 : 93-97.

Berry, J.C., and Lush, J. L., 1939.

High records contrasted with unselected records and with average records as a basis for selecting cows. J. Dairy Sci., 22 : 607-617.

Bonnier, G., and Hansson, A., 1948.

Identical twin genetics in cattle. Heredity $2: 1-27$.

Bosma, K., 1935.

Onderzoekingen omtrent de melkproductierichting in de fokkerij van het Nederlandsche $Z$ wartbonte vee.

Pub., 11 - L. E. B. Fonds.

Chandrashaker, B., 1951.

Genetic and environmental contributions to the economic.characteristics of the Michigan St. Coll. dairy herd. Microfilms Publ., 2703 : 209.

Copeland, L., 1938.

The use of records in evaluating the inheritance of cows and in the proving of bulls. J. Dairy Sci., $21: 651-660$.

Eckles, C. H., 1911.

Dairy cattle and milk production. The Macmillan Co. New York.

Fisher, R. A., 1954.

Statistical methods for research workers. 12th edition, Oliver and Boyd., London.

Gaines, W. L., and Davidson, F.A., 1926.

Rate of milk secretion as affected by advance in lactation and gestation. Ill. Agric. Exp. Sta. Bul., 272. 
Gaines, W. L.,1927.

Milk yield in relation to recurrence of conception. J. Dairy Sci., $10: 117-125$.

Gifford, W., 1930.

The mode of inheritance of yearly butterfat production. Mo. Agr. Exp.Sta. Res. Bul., 144.

Gowen, J. W:, 1920.

Inheritance in crosses of dairy and beef breeds of cattle.

J. Hered., 11 : 300-316; 365-376.

1924.: $\because \cdots$

Milk secretion. Williams and Wilkins., (Baltimore).

1934.

The influence of inheritance and environment on the milk production and butterfat percentage of Jersey cattle. J. Agr. Res. 49 : 433-465.

Groeneveld, B. J. B., 1939-1941.

De vererving van de melkproductie. Alg. Bond van oud-leerlingen van inrichtingen voor middelbaar Landbouwonderwijs.

Jaarboek 1939 : 176-187, Jaarboek 1941:106-115.

Hansen, J., 1917.

Ziele und Grenzen der Kontrolvereine, unter Berlacksichtigung der Vererbung der Milchergiebigkeit.

Arb.dtsch. Ges.Zacht., 23.

Hansson, A., and Bonnier, G., 1949.

Further studies on the genetical determination of the composition of cows' milk with regard to fat, protein, and lactose.

Acta. Agric. (Stockh.), 3 : 179-188.

Hervey, W. R., and Lush; J. L., 1952.

Genetic correlation between type and production in Jersey cattle. J. Dairy Sci., 35 : 199-213.

Heizer, E. E.,1932.

The inheritance of milk production and butter-fat percentage in a herd of purebred Ayrshire cattle. Proc. Amer. Soc. Anim. Prod., 25th Ann. meeting, 1932 : 273-277.

Horn, A., 1950.

Correlation between constitution and milk production of dairy cows. Emp. J. Exp. Agr., 18 : 57-59.

Jensen, E.; Klein, J.W.; Rauchenstein, E.; Woodward, T.E.; and Smith, R. H., 1942.

Input-output relationships in milk production. U.S. D. A. Tech. Bul., 815.

Johansson, I., and Hansson, A., 1940.

Causes of variation in milk and butterfat yield of dairy cows. K. Landtbr Akad. Handl.-Abstract in J. Hered., 1944, 32 : 398 400.

Johansson, 1., 1942 .

Produktionsegenskabernes variation og arvelighed hos malkekvaeget. Tidsskr. Land $\phi k o n ., .2$.

-.--n---- , 1947.

Studier 8ver avkastningsvaristionen inom Svenks Kullig boskap.

K., 937. Landtbr Akad. Tidskr., 86 : 97-140.

, 1949.

Production traits in dairy cattle and their improvement by selection. Ve Congrés International de Zootechnic, Rapports particuliers. Paris, 1949, : 273-279. 
Johansson, I., and Korkman, N., 1952.

Heritability of the udder proportions in dairy cows. Hereditas (Lund)., $38: 131-151$.

Jong, W. de, 1947.

Een halve eeuw productieteelt. Inaugurale rede. - Wageningen.

Kenney, J. F., and Keeping, E. S., 1953.

Mathematics of statistics, Part 2, 2nd edition-New York, Toronto, London.

Keestra, F., and Bakhoven, A. L., 1931.

Rapport Friesland. Off. Org. F. N.Z., 26, $43: 9-18$.

Kramer, Y. M., 1953.

Milk-Veterinary work in the Net'erlands : 236-244. M. Agr.F.F.

Křiženecký, J., 1933.

Dojivost a produkce absolutn.ko tuku V mléce $\mathrm{V}$ pomëru $\mathrm{K}$ tučnosti. Sbov. Cesk. Akad.Zeměd., 8 : A 93-154.

, 1933.

Vztehy mezidojivostí, produkcé absolutníko tuku a procentuální tuX̌ností mléka ve světle Ezekielova t.zv. determinačníko koeficientu. Vest. Cusk. Akad. Zeměd., 10:6-8:

Laben, R.C., 1950.

A study of genetic factors affecting milk production in a selected Holstein-Friesian herd. Univ. Microfilms Publ., 2042 : 158.

Legates, J. E., 1949.

A selection index for butterfat production in Jersey cattle utilizing the fat yields of the cow and her relatives. Doct. Thesis, Iowa State Coll., Ames. From abstract in Iowa St. Coll. J. Sci., $1951,25: 278-279$.

Lush, J. L., 1939.

Methods of measuring the heritability of individual differences among farm animals. Proc. 7th Intern. Cong. of Genet. : 199.

-.-.-.-.- 1940.

Intra-sire correlations or regressions of offspring on dam as a method of estimating heritability of characteristics. 33rd Ann. Pro. of Ames. Socie. of Ani. production.

Lush, J. L., Norton, H. W. (III), and Arnold, F., 1941.

Effects which selection of dams may have on sire indexes. J. Dairy Sci., 24 : 695-721.

Lush, J. L., and Strauss, P.S., 1942.

The heritability of butterfat production in dairy cattle. J. Dairy Sci., 25 : 975-982.

Lush, J. L., 1949.

Animal breeding plans. 3rd. edition. Ames., Iowa.

Lush, J. L., and Shrode, R. R., 1950.

Changes in milk production with age and milking frequency: $\mathrm{J}$. Dairy Sci., 33 : 338-357.

Lush, J. L., and McGilliard, Lon D., 1955.

Proving dairy sires and dams. J. Dairy Sci., Feb. 1955.

Mahadevan, P., 1951.

The effect of environment and heredity on lactation. J. Agric. Sci., 41 : $80-97$ (B.).

Madsen, K., 1932 .

Inheritance of milking capacity. Nature, Lond., $129: 165-166$.

Mather, K., 1949.

Biometrical genetics. 1st edition. Methuen, Lond. 
Midtlid, S., and Berge, S., 1950.

Arveling del av variasjonen hos $\phi$ stlandske raukoller. Meld. Norg, Landbr. Hфgsk., : 115-148.

Patow, C. F. von, 1925.

Studien uber die Vererbung der Milchergiebikeit an hand von funfzigjahrigen Probemelkaufzeichnungen. Zeits. f. Tierz. u. Zacht. biol., 4 : Heft 3.

-............. 1930.

Weitere studien uber die Vererbung der Milchleistung beim Rinde. Zeits. f. Tierz. u. Zacht. biol., $17: 3-158$.

Plum, M., 1935.

Causes of differences in butterfat production of cows in Iowa cow testing associations. J. Dairy Sci., 18 : 811-825.

Podhradský, J., 1940.

(Study on the correlations between milk yield, butterfat, and fat production in Bernese cattle in Moravia). Abst. in Zuchtungskunde, 1942, $17: 172$.

Putman, D. N.; Bowling, G. A.; and Conklin, C. T., 1943.

The use of first records versus the average of all records in dam-daughter comparisons when proving sires. J. Dairy Sci., 26 : 967-973.

Ragab, M. T., Asker, A.A., and Ghazy, M.S., 1953.

Effect of age on total milk yield and length of lactation period in the Egyptian Buffalo. Ind. J. Dairy Sci., 4 : 181-188.

Effect of season of calving, dry period and calving interval on milk yield and lactation period of Egyptian Buffalo. Ind. J. Dairy Sci., $1: 8-18$.

Ragab, M.T., Asker, A.A., and Hilmy, S. A., 1954.

Milk yield in the Egyptian cow as affected by age, dry period, and month of calving. Ind. J. Dairy Sci., 4 : 171-177.

Rennie, J. C., 1951.

Relation between type and butterfat production of Jersey cows in Canada. Sci. Agric., 31 : 553-558.

Rice, V.A., 1942.

Breeding and improvement of farm animals. 3rd. edition. McGraw-Hill book Com., Inc. New York and Lond.

$\ldots \ldots . . . . ., 1944$

A new method for indexing dairy bulls. J. Dairy Sci., 27 : 921936.

Rietz, H. L., 1909.

On inheritance in the production of butterfat. Biometrika, 7 : 106-126.

Smith, B. A. D., and Robison, O. J., 1933.

The genetics of cattle I. Bibliogr. genet., $10: 1-104$.

Snedecor, G. W., 1946.

Statistical methods, 4th edition, Ames., Iowa.

Solocjev, A. A., 1940.

Korreljativnaja zavisimostj mězdu udoem, kolið̌estvom žira i žirnomoločnostjju korov. Trud. vologodsk. sel.-hoz. Inst., 2 : 37-52.

Stichting "Centrale melkcontrôle Dienst" . Jaarverslag. 1954. 
Sikka, L. C., 1950.

A study of lactation as affected by heredity and environment. J. Dairy Res., $17: 231-252$.

Szczckin-Krotov, W., 1938.

Dziedziczenie zawartosci tluszczu W mleku u krow. Przegl. hodowl., $12 ; 48-51 ; 61-67 ; 83-87 ; 112-115$.

Touchberry, R. W., 1951.

Genetic correlations between five body measurements, weight, type, and production in the same individual among HolsteinFriesian cows. J. Dairy Sci., 34 : 242-255.

Turner, C. W. : Ragsdale, A.C.; and Brody, S., 1924.

The relation between age, weight, and fat production in dairy cows. Mo. Agr. Exp. Sta. Bul., 221.

Turner, C. W., 1927.

The mode of inheritance of yearly butterfat production. Mo. Agric. Exp.Sta. Res. Bul., 112.

Tyler, W. J., and Hyatt, G. (Jr), 1947.

The heritability of milk and butterfat production and percentage of butterfat in Ayrshire cattle, J. Anim. Sci., $6: 479-480$.

Vogel, F., and Werkman, N. F., 1952.

Progeny-testing op twee bekende stieren in Nederland. Tijdschrift voor diergeneeskunde. $77: 386-391$.

Ward, A. H., 1940. (After Lush and Strauss, 1942).

"Seventeenth Annual Report of the New Zealand Dairy Board" $1940-41 .,: 37$.

Wing, H. H., and James, A.F., 1904.

Record of an attempt to increase the fat in milk by means of liberal feeding. Cornell Agr. Exp. Sta. Bul., 222.

Winters, L. M., 1950.

Animal Breeding. 4th. edition. Wiley \& Chapman, New York.

Wright, S., 1920.

The relative importance of heredity and environment in determining the piebald pattern of guinea pigs. Proc. of the Nat. Acad. of Sci., $6: .320-332$.

1921.

Systems of mating. I. The biometric relations between parent and offspring. Genetics, $6: 112-123$.

Yapp, W. W., 1928-29.

Dairy cattle and dairy products. Ill. Agric. Exp. Sta. Rep. 123.

Zeller, J., 1951.

Klimatische Einflusse auf den Fettgehalt. Allgău. Bauernbl., 20-12-51. From abst. in Tierzlichter, 1952, $4: 47$. 